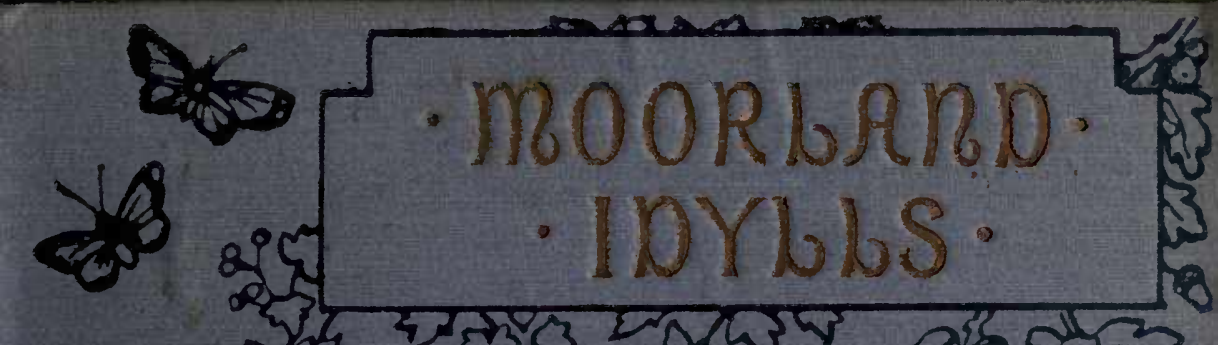

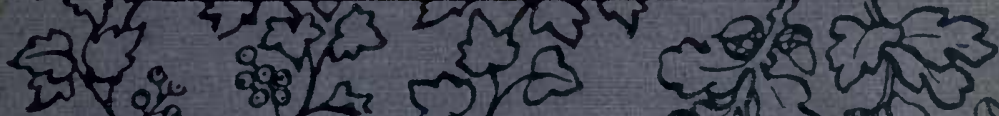

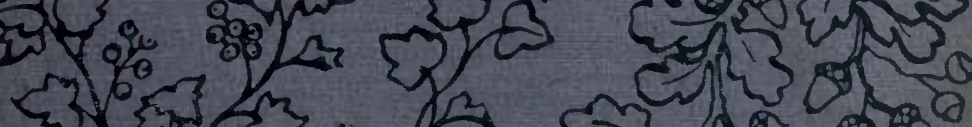

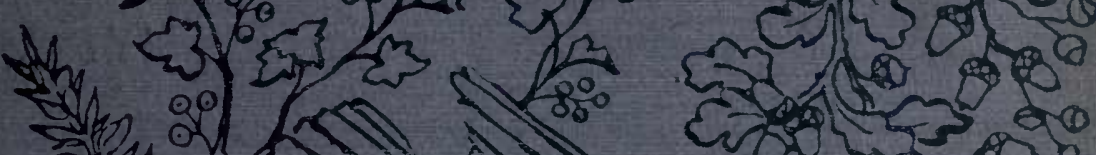
$p_{5}$ a जी

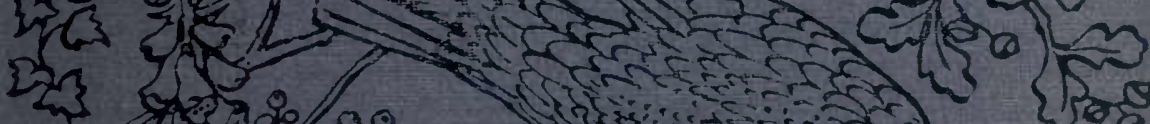
\%) in sil s. 9 6000 है।
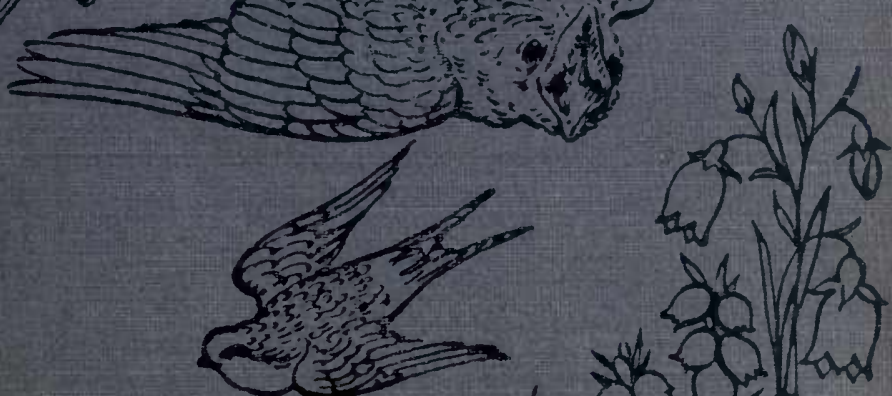

inist 35

a. 5 -

vick $x=20$ ds

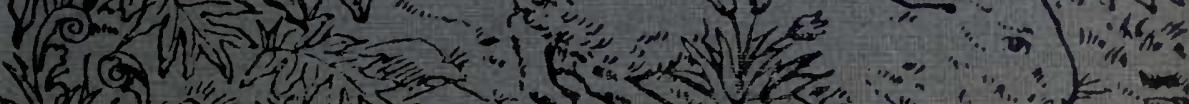
I.

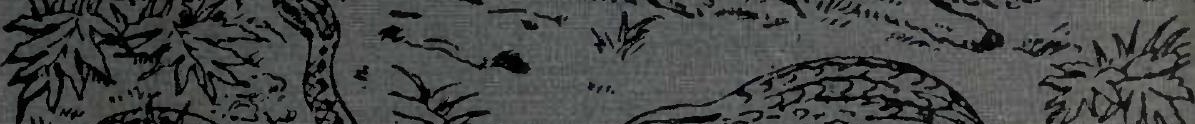
a d w

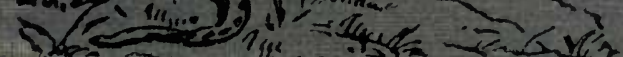





For clear Fatter with Grants love.

MOORLAND IDYLLS

$a$ 


\section{BOOKS BY GRANT ALLEN.}

The Evolutionist at Large. Crown $8 \mathrm{vo}$, cloth extra, $6 s$. Post-Prandial Philosophy. Crown 8vo, art linen, 3s. $6 d$.

Crown $8 \mathrm{vo}$, cloth extra, $3 s$. $6 d$. each; post $8 \mathrm{vo}$, illustrated

Philistia. boards, 2s. each.

Babylon. With 12 Illustrations.

Strange Stories. With Frontispiece.

The Beckoning Hand.

For Maimie's Sake.

In all Shades.

The Devil's Die.

This Mortal Coil.

The Tents of Shem. With Frontispiece.

The Great Taboo.

Dumaresq's Daughter.

The Duchess of Powysland.

Blood Royal.

Ivan Greet's Masterpiece.

The Scallywag. With 24 Illustrations.

Crown 8vo, cloth extra, 3s. $6 d$. each.

At Market Value.

Under Sealed Orders.

[Shortly.

Dr. Palliser's Patient. Fcap. 8vo, cloth boards, rs. $6 d$.

London : CHATTO \& WINDUS, Piccadilly. 
$B .01$

A

\section{MOORLAND IDYLLS}

BY

GRANT ALLEN

AUTHOR OF "THE EVOLU'TÍONIST AT LARGE."
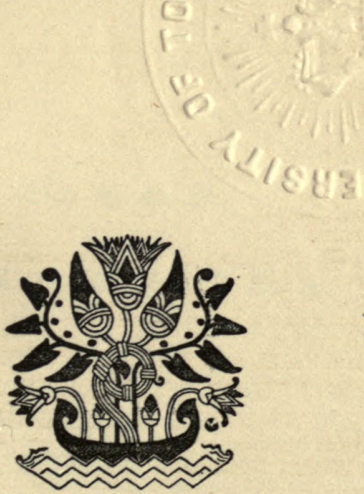

$\frac{370305}{18.8 .39}$

LONDON

CHATTO \& WINDUS, PICCADILLY

I 896 


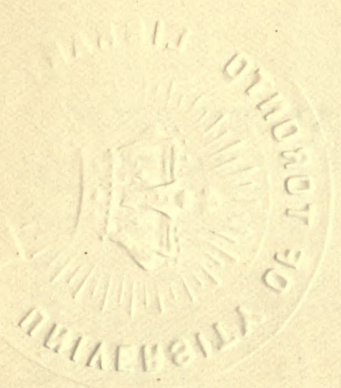




\section{TO A. L. B.}

FROM G. A. AND N. A. 



\section{CONTENTS.}

I. THE NIGHT-JAR PAGE

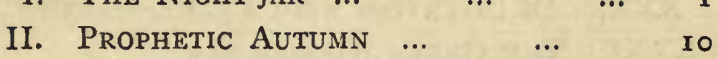

III. OUR WINGED HOUSE-FELLOWS $\quad \ldots . \quad$ I7

IV. A Neighbourly Gossip ... 26

V. A RABBIt OF THE WORLD $\quad \ldots \quad 33$

VI. The Adder's Siesta ... $\quad . . \quad 42$

VII. A FLIGHT OF QUAILS $\ldots . \quad \ldots \quad 49$

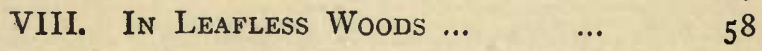

IX. A Butterfly Episode $\ldots . \quad \ldots .65$

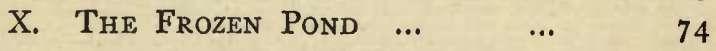

XI. The Gnarled Pine-tree $\ldots$ 8I

XII. IVY IN THE COPSE ...

XIII. A Desperate Struggle for Life ... 97

XIV. Coltsfoot Flowers ... ...

XV. A Heather Episode $\ldots$... II3

XVI. The Chrysalis Year $\ldots$.

XVII. A Summer Stroll $\quad \ldots \quad \ldots \quad \ldots \quad$ I 29

XVIII. A MOORLaNd FIRE ... $\ldots . \quad$ I 38

XIX. The ARcadian Donkey ... $\quad \ldots \quad$ I 45

XX. A Life-ANd-Death Struggle 153 


\section{CONTENTS.}

PAGE

XXI. The Shrike's Larder $\ldots . \quad \ldots \quad 160$

XXII. Nests and No Nests ... 167

XXIII. The CRouch OAK $\ldots . \ldots$ I76

XXIV. A SpotTed ORChIS ... $\quad \ldots . \quad 183$

XXV. The Root of the Matter $\quad \ldots \quad 192$

XXVI. The Devil's Punchbowl ... $\quad x 99$

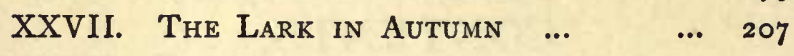

XXVIII. The SQUIRREL'S Harvest ...

XXIX. A Drained Fishpond $\quad \ldots \quad$... 223

XXX. AN INTERVIEW WITH A COCK-SPARROW 230

XXXI. The Green WoOdPecker ... 237

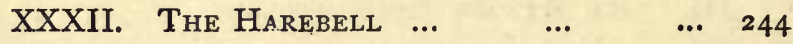

XXXIII. The Untamable Shrew 


\title{
MOORLAND IDYLLS.
}

\author{
I. \\ THE NIGHT-JAR.
}

WE sat late on the verandah last night, listening to the low trilling croon of the night-jar. It was a balmy evening, one of the few this summer; the sunset was lingering over the heather-clad moors, and the lonely bird sat perched on one bough of the wind-swept pine-tree by Martin's Corner, calling pathetically to his mate with that deep passionate cry of his. I know not why, but the voice of the night-jar seems to me fuller of unspoken poetry than that of any more musical and articulate songster. 


\section{MOORLAND IDYLLS.}

Away down in the valley a nightingale was pouring his full throat among the oak-brush; but we hardly heeded him. $U_{p}$ on the open moorland, in the twilight solitude, that grey bird of dusk sat keening and sobbing his monotonous love-plaint; and it moved us more than all the nightingale's gamut. I think it must be because we feel instinctively he is in terrible earnest. Those profound catches in the throat are the very note of true love; they have in them something of high human passion. And we could see the bird himself, too, on his halfleafless perch, craning his neck as he crooned, and looking eagerly for his ladylove. It was a delicious moment. We murmured as we sat George Meredith's lines-

"Lovely are the curves of the white owl sweeping

Wavy in the dusk lit by one large star.

Lone on the fir-branch, his rattle-note unvaried,

Brooding o'er the gloom, spins the brown eve-jar."

We were fortunate indeed in our mise-enscène; for the poet's picture had realized 


\section{THE NIGHT-JAR.}

itself before us. And, as usual, art had reacted upon nature. The cry, that was so beautiful and romantic in itself, gained an added touch of beauty and romance from the great word-painter's exquisite images.

Perhaps, too, some part of the charm in the night-jar and his kind may be due to the sense that here at least we stand face to face with a genuine relic of the older, the wilder, and the freer England. $\mathrm{He}$ is a bird of the night, of the heather and the bracken, of the unbroken waste, of the unpeopled solitude. When man invades his high home, he moves afield before the intruder. Here on the great moors we hear him nightly in summer; but only when no other sound assails the ear, save the boom of the cockchafer, and the myriad hum of the flies and moths of dusk among the heather. He belongs, in fact, to that elder fauna which inhabited England before the whirr of wheels and the snort of steam drove the wild things far from us. The perky 


\section{MOORLAND IDYLLS.}

sparrow can accommodate himself without an effort to the bustle of towns, and can dispute for grains of corn under the horses' hoofs in Cheapside; the rook can follow close the ploughman's heels, in search of worms turned up by the share in the furrows; but the night-jar lives aloof among the solitary fern-wastes, and flies amain before the intrusion of our boisterous humanity.

"Fern-owls" the country people hereabouts call them; and very owl-like indeed they are in outer appearance, with their soft mottled plumage, all brown and grey and melting white, as is the wont of nocturnal or crepuscular creatures. But they are not owls at all by descent, for all that, being in reality big fly-hunting cousins of the swifts and the humming-birds. All birds that hawk after insects on the wing have a wide gaping mouth; the house martins have it, and the swallows, and the swifts; but in the night-jar this width of gape is 


\section{THE NIGHT-JAR.}

pushed to a singular and almost grotesque extreme, though not of course beyond the limit laid by the needs and habits of the animal. It is the enormous mouth, fringed with its strange line of coarse bristles along the beak, that has gained for our night-jar its common European name of goatsucker. And indeed, if you watch close on southern upland farms, among the Apennines or the Atlas, you will see the night-jars at twilight hovering close by the udders of the goats and cattle as they lie stretched in the meadows. But they are not milking them, as the Italian peasant firmly believes; it is as friends and allies that they come, not as enemies. Peer hard through the gloom, on a moonlit evening, and you can make out at last that nocturnal flies are annoying the beasts, and that as fast as they gather the night-jar snaps them up, while the cattle seem to recognize this friendly office by never whisking their tails so long as the bird attends to them. It is a mutual 


\section{MOORLAND IDYLLS.}

convenience, an early form of that consorting for purposes of common advantage which reaches at last its highest development in the nest of ants, with their associated beetles and their cow-like aphides.

Here in England, our night-jar is but a summer migrant, a visitor to the moors while insects abound; and we listen for him eagerly in warm May weather. $\mathrm{He}$ comes to us from South Africa, where he winters among the $Z$ ulus, or, rather, escapes the chill of winter altogether in the opposite hemisphere. For he must have insects, flying insects on the wing, and plenty of them. We welcome his first churring among the pines and bracken as a sign of summer; for he is a prudent bird, and seldom makes a mistake, knowing the marks of the weather well, like Mr. Robert Scott, and delaying his arrival till insects have hatched out in sufficient numbers from the cocoons over the heather-clad uplands. You see him but rarely, for he loves the dusk, and, 


\section{THE NIGH'T-JAR.}

though far from a timid bird, he usually alights on the ground, hardly perching on a tree, I think, except to utter his love-call. When he does perch, it is always lengthwise to the bough, not crosswise, as is the fashion with most other birds; he seems afraid of falling; and then, this position also assorts better with his passionate attitude of craning expectancy as he leans forward on the branch to summon his helpmate. If you disturb him from the ground, he rises with flapping wings in an awkward and noisy way, bringing his pinions together above his body, somewhat after the lapwing's fashion; but when he hawks on the open after flies, with his big mouth agape, his long arcs of flight are equable, swift, and graceful. Night-jars are fearless beasts; they rear their young in the open, without pretence or concealment. The two veined and marbled eggs are laid boldly in some hard patch among the brake and gorse, on the bare ground, without a nest of any sort; 


\section{MOORLAND IDYLLS.}

and though they are beautifully coloured when you come to examine them in detail, they so closely imitate the soil and the dry heath around in general effect, that you may easily pass them by, even when you have marked their approximate place by disturbing the sitting mother. Few British birds, indeed, show higher and closer adaptation to special conditions than our dreamy nightjars, essential insect-hawkers of the dusk on open and treeless uplands. Their large and mysterious eyes, their gaping mouths, their straining fringe of bristles, their delicate owl-like plumage, their swift and silent flight, their agile movements, their eerie cry, their curious love-sick nature-all mark them out as marvellously modified nocturnal variants on the general type of the swifts and trogons. They are, in fact, specialized descendants of the same primitive ancestral form, whose bodies and souls have undergone weird and beautiful changes in adaptation to a wild and poetical life in the shades of 


\section{THE - NIGHT-JAR.}

dusk on the unpeopled moorlands. For birds of twilight have always passionate cries and passionate natures; not accident alone has given us the whip-poor-will and the nightingale. 
II.

\section{PROPHETIC AUTUMN.}

THE year used once to begin in March. That was simple and natural-to let it start on its course with the first warmer breath of returning spring. It begins now in January - which has nothing to recommend it. I am not sure that Nature does not show us it really begins on the first of October.

"October!" you cry, "when all is changing and dying! when trees shed their leaves, when creepers crimson, when summer singers desert our woods, when flowers grow scanty in field or hedgerow! What promise then of spring? What glad signs of a beginning?"

Even so things look at a superficial glance. 


\section{PROPHETIC AUTUMN.}

Autumn, you would think, is the season of decay, of death, of dissolution, the end of all things, without hope or symbol of rejuvenescence. Yet look a little closer as you walk along the lanes, between the golden bracken, more glorious as it fades, and you will soon see that the cycle of the year's life begins much more truly in October than at any other date in the shifting twelvemonth you can easily fix for it. Then the round of one year's history draws to a beautiful close, while the round of another's is well on the way to its newest avatar.

Gaze hard at the alders by the side of this little brook in the valley, for example, or at the silvery-barked birches here on the windswept moorland. They have dropped their shivering leaves, all wan yellow on the ground, and the naked twigs now stand silhouetted delicately in Nature's etching against the pale grey-blue background. But what are those dainty little pendulous cylinders, brown and beaded with the mist, 


\section{MOORLAND IDYLLS.}

that hang in tiny clusters half-unnoticed on the branches? Those? Why, can't you guess? They are next April's .catkins. Pick them off, and open one, and you will find inside it the wee yellowish-green stamens, already distinctly formed, and rich with the raw material of future golden pollen. The birch and the alder toiled, like La Fontaine's ant, through all the sunny summer, and laid by in their tissues the living stuff from which to produce next spring's fluffy catkins. But that they may lose no time when April comes round again, and may take advantage of the first sunshiny day with a fine breeze blowing for the dispersal of their pollen, they just form the hanging masses of tiny flowers beforehand, in the previous autumn, keep then waiting in stock, so to speak, through the depth of winter, and unfold them at once with the earliest hint of genial April weather. Observe, though, how tightly the flowerets are wrapped in the close-fitting scales, overlapping like Italian 


\section{PROPHETIC AUTUMN.}

tiles, to protect their tender tissues from the frost and snow; and how cleverly they are rolled up in their snug small cradles. As soon as spring breathes warm on them, however, the close valves will unfold, the short stamens will lengthen into hanging tassels, and the pollen will shake itself free on the friendly breezes, to be wafted on their wings to the sensitive surface of the female flowers. Look, again, at the knobs which line the wand-like stems and boughs of the willows. Do you know what they are? Buds, you say. Yes, leaves for next spring, ready-made in advance, and curled up in embryo, awaiting the summer. If you unfold them carefully with a needle and pocket-lens, you will find each miniature leaf is fully formed beforehand : the spring has even now begun by anticipation; it only waits for the sun to unfold and realize itself. Or see, once more, the big sticky buds on the twigs of the horse-chestnut, how tightly and well they protect the new leaves; and notice at 


\section{MOORLAND IDYLLS.}

the same time the quaint horseshoe scar, with marks as of nails, left where the old leaves have just now fallen off, the nails being, in point of fact, the relics of the vascular bundles. Death, says the old proverb, is the gate of life. "Le roi est mort; vive le roi!" No sooner is one summer fairly over than another summer begins to be, under the eyes of the observer.

To those among us who shrink with dread from the Stygian gloom of English winter, there is something most consoling in this cheerful idea of Prophetic Autumn-this sense that winter is but a temporary sleep, during which the life already formed and well on its way to flower and foliage just holds its breath awhile in expectation of warmer weather. Nay, more, the fresh young life of the new year has even begun in part to show itself already. Autumn, not spring, is the real season of seedlings. Cast your eyes on the bank by the roadside yonder, and what do you see? The ground 


\section{PROPHETIC AUTUMN.}

is green with tiny baby plants of prickly cleavers and ivy-leaved veronica. The seeds fall from the mother-plant on the soil in August, sprout and germinate with the September rains, and have formed a thick carpet of spring-like verdure by the middle of October. That is the common way with most of our wild annuals. Unlike so many pampered garden flowers, but like "fall" wheat in cold climates, they sow themselves in autumn, come up boldly at once, straggle somehow through the winter, of course with enormous losses, and are ready by spring to welcome the first rays of returning sunshine.

Even the animals in like manner are busy with their domestic preparations for next summer. The foundress wasps, already fertilized by the autumn brood of drones, are retiring with their internal store of eggs to warm winter quarters, ready to lay and rear them in the earliest May weather. The dormouse is on the look-out for a snug hiding-place in the hazels. The caterpillars 


\section{MOORLAND IDYLLS.}

are spinning cocoons or encasing themselves in iridescent chrysalis shells, from which to emerge in April as full-fledged moths or gay cabbage butterflies. Everything is preparing for next summer's idyll. Winter is but a sleep, if even that; thank Heaven, I see in autumn the "promise and potency" of all that makes June sweet or April vocal. 
III.

\section{OUR WINGED HOUSE-FELLOWS.}

WE have been sitting this afternoon in the Big Drawing-room, enjoying the view from its extensive windows. It is a spacious apartment for so small a house-about three acres large, with windows that open all round over miles of moorland. The carpet has a groundwork of fallen pine-needles and green grass and bracken, irregularly threaded with a tiny pattern of brocaded flowers-yellow tormentil, white bedstraw, golden stonecrop, red sheep-sorrel; while by way of roof the room is covered by a fretted ceiling of interlacing fir-branches, through which one can catch at frequent intervals deep glimpses of a high and bright blue dome that overarches 


\section{MOORLAND IDYLLS.}

with its vast curve the entire Big Drawingroom. No finer throne-hall has any earthly king; it is quite good enough for ourselves and our visitors.

But as we leaned back in our easy-chairs -spring seats of brake, backed with a bole of red pine-bark-we gazed upward overhead through the gaps in the boughs, and saw our winged house-fellows, the blackand-white martins, sweeping round in long curves after flies in the sunshine. It was immensely picturesque for the martins and ourselves; how the flies regard the question I forbear to inquire at the present juncture. We had lamb chops for lunch; let him that is without sin amongst us-for example, the editor of the Vegetarian Times-cast the first stone at the house-martins. For myself, I am too conscious of carnivorous and other sinful tastes to cast stones at anybody. We are all human, say $I$, or at any rate vertebrate; let us agree to take things with vertebrate toleration. 


\section{OUR WINGED HOUSE-FELLOWS.}

The house-martins abide under the same roof with ourselves; literally under the same roof, for their tiny mud nests cling close beneath the eaves of our two spare bedrooms, familiarly known as the Maiden's Bower and the Prophet's Chamber-the last because it is most often inhabited by our friend the curate, and furnished, after the scriptural precedent, with "a bed, and a table, and a stool, and a candlestick"- "Every luxury that wealth can afford," said the Shunammite lady. "Under our roof," we say, when we speak of it; but the house-martins think otherwise. "Goodness gracious," I heard one of them twitter amazed to his wife the day we moved in for the first time to our newly-built cottage, "how terribly inconvenient! Here are some of those great nasty creatures, that walk so awkwardly erect, come to live in our house without so much as asking us. How they'll frighten the children!" For to tell you the truth, they were here before us. 


\section{MOORLAND IDYLLS.}

They came while the builders were still occupied in giving those "finishing touches" which are never finished; and they regarded our arrival as an unwarrantable intrusion. I could tell it from the aggrieved tone in which they chirped and chattered: "Gross infringement of the liberty of the subject;" "In England, every martin's nest is called his castle;" "Was it for this our fathers fought and bled at Agincourt against the intrusive sparrows?" -and so forth ad in-

finitum. But after a day or two, they cooled down and established a modus vivendi, the terms of the concordat being that we mutually agreed to live and let live, they under the eaves, and we in the interior. Since then, this arrangement has been so honourably carried out on both sides by the high contracting parties, that the martins allow us to stand close under them on the garden terrace, and watch while they bring flies in their mouths to their callow young, which poke out their gaping mouths at the 


\section{OUR WINGED HOUSE-FELLOWS.}

nest door to receive them. They know us individually, and return with punctuality and despatch to their accustomed home each summer. But when strangers stand by, I notice that, though the parent birds dart back to the nest with a mouthful of flies, they do not dare to enter it or to feed their young; they turn hurriedly on the wing, three inches from the door, with a disappointed twitter, a sharp cheep of disgust, and won't return to their crying chicks, which strain their wide mouths and crane their necks to be fed, till the foreign element has been eliminated from the party.

For myself, I will admit, I just love the house-martins. They may be given to eating flies; but what of that? The skylark himself-Shelley's skylark, Meredith's skylark-affects a diet of worms, and nobody thinks one penny the worse of him. Even Juliet, I don't doubt, ate lamb chops like the rest of us. Indeed, it happened to me a few mornings since, during some very hot 


\section{MOORLAND IDYLLS.}

weather, to be positively grateful for these insectivorous tastes on the part of our feathered fellow-citizens. We were sitting on the verandah, much tried by a plague of flies; it was clear that "the blood of an Englishman" attracted whole swarms of midges and other unwelcome visitors. As soon as the house-martins became aware of this fact, they drew nearer and nearer to us in their long curves of flight, swooping down upon the insects attracted by our presence before they had time to arrive at the verandah. We sat quite still, taking no notice of the friendly birds' manœuvres ; till after a while they mustered up courage to come close to our faces, flying so low and approaching us so boldly, that we might almost have put out our hands and caught them. I am aware, of course, that the martins merely regarded us from the selfish point of view, as fine bait for midges; while we in return were glad to accept their services as vicarious flycatchers. But on what 


\section{OUR WINGED HOUSE-FELLOWS.}

else are most human societies founded save such mutual advantage? And do we not often feel real friendship for those who serve us for hire well and faithfully? In the midst of so much general distrust of man, I accept with gratitude the confidence of the house-martins.

All members of the British swallow-kind are amply represented in and about our three acres. The common swallows breed under the thatched eaves of the ruined shed in the Frying Pan, and hawk all day over the shallow trout-stream that bickers down its middle. You can tell them on the wing by their very forked tail. It is, I think, in part a distinguishing mark by which they recognize their own kind, and discriminate it from the martins; for the outer-tail feathers are particularly long and noticeable in the male birds, whence I take them to be of the nature of attractive ornaments. At the beginning of the breeding season, too, the males assume a beautiful pinky blush on 


\section{MOORLAND IDYLLS.}

the lighter parts of the plumage, which may specially be observed as they turn flashing for a moment in bright April sunshine. The sand-martins, again, the engineers of their race, have excavated their long tunnelled nests in the crumbling yellow cliff that flanks the cutting on the high road opposite; I love to see them fly in with unerring aim at the narrow mouth as they return all agog from their aërial hunting expeditions on cool summer evenings. They are the smallest and dingiest of our swallows; they have no sheeny blue-black plumage like their handsome cousins, but are pale brown above, and dirty white below. The house-martin, last of all, can be recognized at once upon the wing by his conspicuous belt of pure white plumage, almost dazzling in its brilliancy, which stretches in a band across the lower half of his back; as he pirouettes on the wing, this badge of his kind gleams for a moment against the sky, and then fades as if by magic. His shorter 


\section{OUR WINGED HOUSE-FELLOWS.}

tail scarcely shows forked at a distance, but when you watch him at close quarters, it is delightful to observe how he broadens or narrows it as he flies, to steady and steer himself. In order fully to appreciate this point, however, you must have the quick keen eye of the born observer. As for the pure black swifts-those canonical birds that haunt the village steeple-they are not swallows at all, but dark and long-winged northern representatives of the humming-birds and trogons. All these alike are summer migrants in England, for they can but come to us when insects on the wing are cheap and plentiful. 
IV.

\section{A NEIGHBOURLY GOSSIP.}

I LOVE gossip. For my own part, I can never see the point of the objections which some people raise against talking over the concerns of your neighbours' families. They are always so interesting. I like to know all about them. I like to pry into their most intimate secrets. I like to find out what they do with themselves all day long; and what they have to eat for dinner; and how they make their living; and where or in whose company they spend their evenings.

I like to watch where they build their homes, and how many eggs they lay, and how they hatch them out, and what becomes of the fledgelings. I like to spy out where others 


\section{A NEIGHBOURLY GOSSIP.}

hibernate in the woods, and what store of nuts and fruits they have laid by to provide against the Christmas scarcity. You may think this sort of Paul Pry interest in the affairs of your fellow-creatures is undignified and unphilosophic; but I confess, to me it appears only neighbourly.

For example, there are my friends the missel-thrushes, who have just lately returned for the winter months to their commodious quarters in the hanger below me. A week or two since I noticed them flying home to the woods and parks in their thousands. They have been spending the summer months as usual on their moors in Norway; but food having lately begun to fail them on the fjelds, they are coming back now in great straggling flocks to their English residences. For, unlike the song-thrush, who is one of their closest and most distinguished relations, they stay with us in the winter only, and move north again betimes in late spring, as soon as their broods are reared and whortle- 


\section{MOORLAND IDYLLS.}

berries are getting plentiful in the northern moorlands.

Questions of commissariat, indeed, have most to do with the migrations of birds; it is not weather, as weather, but the condition of the food-supply that mainly regulates their periodical movements. Now, the misselthrush is almost entirely vegetarian in his habits; whereas his cousin, the song-thrush, subsists for the most part on a regimen of worms and other miscellaneous unsavoury animals. Hence it follows, of course, that the missel-thrush must needs go where berries are in season; he follows them closely across the face of Europe, from province to province He cannot stand great cold, however, and often freezes to death in severe winters; which is another reason why he comes south for warmth when Norwegian hills rise white with snow, and fjords are blocked with ice, and crystal-frosted pine-trees glisten in the sun with innumerable diamonds. Family parties of missel-thrushes may be seen in 


\section{A NEIGHBOURLY GOSSIP.}

our fields the whole winter through; but they are timid and wary, and fly off in a body at the faintest suspicion of coming danger. You can tell them as they rise on the wing by the conspicuous white patch under the pinions, which seems, like the rabbit's tail, to act as a danger-signal to the rest of the household. No sooner does one of them scent a stranger afar off than he rises silently, and the others, alarmed by his contagious fear, rise after him one by one in a picturesque line, somewhat as one often sees in the case of wild-fowl. In February and March your missel-thrush begins to build in the hawthorns and apple-trees; and the moment his nestlings are strong enough of wing to buffet the strong winds of the German Ocean, the whole family flits north again to its Norwegian estate for the cloudberry season. The nests, however, though built somewhat overtly on bare and leafless boughs, are most difficult to find; for the cunning little architects, knowing well they 


\section{MOORLAND IDYLLS.}

will get no protection from a canopy of foliage, conceal their homes adroitly with an outer coat of woven moss and lichen, which so harmonizes with the grey and lichencovered branches around them as to make them almost indistinguishable. The eggs are stone-grey, daintily spotted and blotched with round blobs of brown ochre.

But by far the most interesting point about the missel-thrush is that curious connection between the bird and the mistletoe which was observed so long since even by our prehistoric ancestors as to have given the species its vernacular name in all European languages. Turdus viscivorus - the mistletoeeating thrush-is Linnæus's scientific Latin title for the creature, and he well deserves it. $\mathrm{He}$ is almost or altogether the only bird that will eat the mistletoe berries, and on him accordingly the mistletoe depends for the dispersal of its seeds and the propagation of its mystic parasitic seedlings. The berries themselves are very "viscid," as we say- 


\section{A NEIGHBOURLY GOSSIP.}

the word itself being derived from the Latin name of mistletoe-and the seeds cling close, as if gummed or glued, to the bird's beak and feet in a disagreeable fashion. So, to get rid of them, he alights on an apple-tree or a poplar, which are his favourite perches, betakes him at once to an angle of a bough, and rubs off the annoying and sticky objects in the fork of the branches. There they fasten themselves. and germinate. Now, this arrangement exactly suits the mistletoe, for apple and poplar are just the two trees best adapted for its depredations, while a fork in a bough is the one likely place where it has a chance of rooting itself. A great many unobservant people imagine to-day that mistletoe grows chiefly on oaks, because they have heard about the sanctity of oakgrown mistletoes in the eyes of the Druids. The real fact is, as you may learn for yourself if you will look at nature instead of merely reading about it at second or third hand, that mistletoe on an oak-tree is ex- 


\section{MOORLAND IDYLLS.}

tremely rare; the Druids prized it because they thought it the life or soul of the oak, which was the sacred tree of Celtic mythology. I notice, indeed, that missel-thrushes very seldom perch on oaks; and even when they do by chance dislodge a stray seed of mistletoe on one, it has difficulty in fixing its young suckers on the alien bark, and draining the tree's nutritious juices. The truth is, the mistletoc and the missel-thrush are developed for one another; they have struck up an alliance from time immemorial on terms of mutual service and accommodation. 


\section{V. \\ A RABBIT OF THE WORLD.}

A Literary Lady, sentimental as was the wont of literary ladies before the incarnation of the New Woman, went once to call on a Great Poet, who pervaded these regions. But the Great Poet was coy, says the legend, and listened not to the voice of the Literary Lady, charmed she never so wisely. He refused to be drawn by her cunning blandishments, but smoked on in peace, glaring gruffly from his chimney corner. So at last the Great Poet's wife, feeling that the situation grew slightly strained, endeavoured to create a diversion by saying, " $\mathrm{My}$ dear, won't you take Mrs. Gusherville to see the garden?" The Great Poet, thus 


\section{MOORLAND IDYLLS.}

checkmated, rose unwillingly from his scat, and strode three paces ahead through the shrubbery paths, followed, longo intervallo, by the panting Mrs. Gusherville. Never a word did he say as he paced the lawn with his heavy tread; but at last, as he approached one garden border, he turned towards his visitor. Speech trembled on his lips; Mrs. Gusherville leant forward to catch the immortal accents. The Poet spoke. " $\mathrm{D}-\mathrm{mn}$ those rabbits!" he said; and then relapsed into silence. That was all Mrs. Gusherville got out of her interview.

I am reminded of this episode, which if not true to fact is at any rate true to human nature, by the short sharp barking of Fan, my neighbour's spaniel, resounding from the heather in the direction of the Frying Pan. Each bark is an eager impatient snap, and its burden is-" Rabbits!" Now, I sympathize with every living thing that breathes; yet if it were not for a constitutional objection to unnecessary vigour of language, I 


\section{A RABBIT OF THE WORLD.}

could almost back Fan, and echo the Great Poet's indignant exclamation. For whatever we try to plant among the heather, by way of beautifying our small patch of moorland (as who should paint the lily or gild refined gold), those unscrupulous rodents immediately proceed to treat as their private property. Not one of our white brooms has survived their attacks; and the way they have devoured our periwinkles and our St. John's wort is a credit to their appetites, and a testimonial to the magnificent air of this healthy neighbourhood. The lad who attends to my garden (we call it a garden by courtesy, not to hurt its feelings) is always saying to me, "Let me set a trap for 'em, sir." But grave as their misdemeanours are, I can't bear to trap them. I remember that after all they were the earliest inhabitants. They dwelt here before me; and when I plumped down my cottage in the midst of their moor, I seriously interfered with their domestic economy. "There's a horrid house 
built," said the mother rabbit: "I suspect a dog will follow, and perhaps a gun too." "Never mind," said the father, who was a rabbit of the world; " they'll more than make it up to us, I predict, by planting greenstuff, which is a deal juicier, after all, than gorse or bracken."

And, indeed, I feel I owe a duty to these earlier inhabitants; I love their fellowship, and do what I can to encourage their uninterrupted residence. The night-jar still perches nightly on one accustomed branch of the big lone fir-tree; the cuckoo comes and calls to us from the clump of stunted pines by the dining-room window; the merry brown hares dart obliquely across the illgrown green patch of tennis-lawn; and the baby bunnies themselves, all unconscious of their misdemeanours against the growing shrubs, brush their faces before our eyes with their tiny grey paws as we sit upon the terrace. My neighbour has a shot at them with gun and $\operatorname{dog}$; and even as I 


\section{A RABBIT OF THE WORLD.}

write, I can hear the ping, ping of his murderous cartridges and the quick cries of Fan in the adjoining plot of moor; but for myself I refrain. I would rather have the gambolling of such innocent fellow-creatures on my patch of grass in the dusk of evening than all the rhododendrons and azaleas and cypresses the florist can palm upon me.

And how pretty they are, those harmless little malefactors! How they frolic across the sward with tiny irregular jumps, like a sportive kitten, only ten times more guileless - no tinge of bloodthirstiness in their liquid eye, no stealthy cruelty in their honest grey faces! Your rabbit is a decent and inoffensive vegetarian. Besides, its mode of life sorts well with the uplands; it never disfigures nature, but accommodates itself to the environment like a good working evolutionist. When we first thought of building here, a clever Girton girl, whom we met at the little inn, held up her hands 


\section{MOORLAND IDYLLS.}

in horror. "Why build on Hartmoor at all ? Why not simply burrow?" And the rabbits burrow. The hill-top is just honey-combed with their underground palaces. There they lurk for the most part during the heat of the day, and come out at night to feed on the furze-bushes that protect and conceal the mouths of their burrows. Indeed, the very shape of the furze-bush, as we ordinarily know it, depends on the constant activity of the hungry and greedy bunnies. Naturally, gorse, if left to itself, would grow feathery from the soil upward, without any gaunt stretch of naked stem at its base; but the rabbits eat off the growing shoots just as high as they can reach by standing tip-toe on their hind feet; so that the resulting shape is a product, so to speak, of rabbit into gorse-bush. Where the soil is light and sandy, as here, burrowing is universal; but on cold wet moors, the rabbits avoid the chance of rheumatism by constructing long tunnels above ground instead, 


\section{A RABBIT OF THE WORLD.}

through matted galleries of heather and herbage.

Cowardice is the principal defence of the rabbit, as of all other unarmed rodents. At the first alarm, he flies headlong to his burrow. What swiftness of foot does for the open-nesting hare, that swiftness of retreat does for his underground cousin. Natural selection in such a case favours the most cowardly; for to be brave is to court immediate extinction. That is why rabbits have the noticeable patch of white under their tails-their scuts, as sportsmen very aptly call them. At first sight you would suppose such a conspicuous white mark must be a source of danger. In reality it has been evolved as a patent safety-signal. For while the rabbits crouch and feed, unseen in the grey grass, they are very little conspicuous; but the moment one of them spies any cause of alarm, off it scampers to its hole; and, raising the danger-signal as it goes, it warns the whole warren, all whose 
members scuttle after it apace without waiting to inquire into the nature of the panic. The mouth of the burrow runs quite straight just at first, so that the retreating bunny can dash into it at full speed without checking his pace; but at a convenient point, a few feet.in, it begins to bend and divaricate, besides branching and subdividing as a precaution against weasels and other vermin enemies. It has also at least two entrances and exits, like a room at the theatre, in case of pursuit; and it is cunningly engineered against the chance of intrusion. But the nursing-chamber, where the timid wee mother hides her naked and shapeless young, is quite differently contrived with but a single mouth, and is fitted up with every internal luxury. The good parent lines it with soft fur pulled from her own warm coat, and goes stealthily by night to suckle her little ones. When she comes away, she plasters up the entrance with earth to conceal it as well as she can from 


\section{A RABBIT OF THE WORLD.}

prying enemies; and there the baby rabbits remain alone in the dark till her next visit. Three or four such broods are produced each year, for your rabbit is indeed an uxorious - creature. 
VI.

\section{THE ADDER'S SIESTA.}

Two "hedgers and tiners," demolishing a bank of earth at Turner's Corner as I walked along the Headley Road this morning, came, to their great surprise and no little horror, on a coiled and twisted colony of hibernating adders. I paused in my stroll for ten minutes to watch the unearthing. It was a curious sight; the lithe and sinuous creatures, recognizable at once as genuine vipers by the zigzag pattern of dark diamond-shaped spots down their glossy green backs, lay curled and entwined with one another in snaky amity, fast asleep past waking, and completely filling up, as with a living mass of inextricable knots, 


\section{THE ADDER'S SIESTA.}

the curves and crannies of the underground hole where they had taken refuge. They were there, of course, for their little winter siesta, which occupies them for a trifle of six months at a sitting. I pleaded hard for their lives with the men, explaining most earnestly that they would do much more good than harm, from the point of view of those whose talk is of beeves, and who regard standing corn as the one really sacred object in this beautiful universe. But I need hardly say my special pleading proved of no avail; the hedgers chopped them up fine before my eyes with their murderous spades, on the familiar antique principle of "larning them to be adders." Poor helpless creatures, expiating thus unaware the delicta majorum! They would have killed more mice in a week than the men could catch in a summer; but they were snakes for all that, and your rustic hates and shrinks from snakes, et dona ferentes.

The adder's siesta is just as much a part 


\section{MOORLAND IDYLLS.}

of his fixed yearly cycle as the fall of the leaf is to the tree, or migration towards warmer lands is to the swallow or house-martin. Snakes can't migrate; because, of course, they've got no wings to migrate with; and being chilly creatures, evolving little animal heat of their own from their sluggish circulation, and warmed by the sun alone into spasmodic activity, they are compelled to bury themselves in holes in the ground, where they lie close to all others of their species that they can find, so as to utilize in common, by mutual aid, whatever trifle of bodily warmth they possess between them. Indeed, a snake, like a tree, can only be said really to live for half its lifetime; the other half these Persephones of the north spend underground in the torpid condition. The heart almost entirely ceases to beat; the lungs cease to act; sensation is suspended; and the animal dozes away his time unconsciously till the summer warmth of the surface soil begins 


\section{THE ADDER'S SIESTA.}

once more to revive him. Then he ventures forth timorously from his hole on some bright May morning, to see how things are progressing in the upper world; and meeting, peradventure, some belated shrewmouse or some early spring chicken, makes a dash at it at once with what life he has left in him, strikes it with his poison-fang, and, swallowing it whole, straightway regains fresh fuel for the battle of existence.

Adders were always friends of mine. They are numerous hereabouts, on our heathy uplands; and for my own part, I do my best to protect and preserve them. For we have not so many wild creatures left in England that we can afford to despise any lingering element of our native fauna. Besides, they do next to no practical harm; occasionally, indeed, they may spring at a dog who provokes their otherwise placid and meditative tempers by treading on them in the heather; and they will still more rarely make $a$ dash at a man who 


\section{MOORLAND IDYLLS.}

incautiously handles them ; but as a rule they are timid and rather sluggish creatures, much more likely to take fright and flee when discovered than to turn and rend one. I come across them frequently on basking paths among the heath in summer; they lie sunning themselves on the warm sand; but when I endeavour to rouse them to resistance by poking at them with my stick, they refuse, as a rule, to show fight, and after a few minutes of hesitation and lazy reluctance to move, they retire in high displeasure to their home among the bracken. Never once have I known them try actively to resent my intentional intrusion on their post-prandial reflections.

We have but two kinds of snakes, all told, in England, popular prejudice to the contrary notwithstanding. One of them is the harmless and pretty ring-snake, easily distinguished by the absence of the rhomboidal zigzag markings; the other, who may as easily be recognized by their presence, is 


\section{THE ADDER'S SIESTA.}

the venomous adder, known also under his frequent alias as the viper, and often supposed to be two distinct creatures. In reality, one reptile doubles the parts, as an actor would say, being but a single snake under two disguises. The adder is remarkable for bringing forth its young alive, instead of hatching them out of eggs, like most typical serpents; and the very name viper is short for vivipara. As for the blindworm, or slow-worm, who is also one animal masquerading under two aliases, he must not be considered a snake at all, being a legless lizard, who tries deceptively to pass himself off in serpent's clothing. Nay, he is not even, strictly speaking, legless, for he has rudimentary limbs, with bones to match, though they never quite succeed in pushing themselves through the scaly integument. $\mathrm{He}$ is a lizard, in short, arrested on his road to complete serpenthood. Neither the ringsnake nor the blind-worm is in the slightest degree dangerous; but when in doubt as 


\section{MOORLAND IDYLLS.}

to whether a particular crawling animal is an adder or otherwise, it would be safer to give him-and yourself-the benefit of the doubt, by abstaining from handling him. The poison-fangs of the viper are two in number, set in the upper jaw; they are hollow, perforated, and erectile at will by the muscles of the animal. Their poison is secreted by a gland at the back, which communicates through a tube with the canal in the fang; and it is not really so very venomous. But if you provoke an adder overmuch, and he sees a chance of remonstrating with you, I do not deny that he will throw back his smooth head, erect his angry fangs, dart quickly forward, and express his disagreement by inflicting a bite upon the offender's trousers. In this he acts much as you and I would do if he were a man and we were adders. Put yourself in his place, and you will think less ill of him. 


\section{A FLIGHT OF QUAILS.}

IT is one of the wonders and delights of the moorland that here alone Nature pays the first call, instead of demurely waiting to be called upon. Near great towns she is coy; and even in the fields that abut on villages, she shows but a few familiar aspects; while aloof on the open heath she reveals herself unreservedly, like a beautiful woman to her chosen lover. She exhibits all her moods and bares all her secrets. This afternoon, late, we were lounging on the low window-seat by the lattice that gives upon the purple spur of hillside, when suddenly a strange din as of half-human voices aroused our attention. "Look, look!" Elsie 


\section{MOORLAND IDYLLS.}

cried, seizing my arm in her excitement. And, indeed, the vision was a marvellous and a lovely one. From the lonely pinetree that tops the long spur above the Golden Glen, a ceaseless stream of brown birds seemed to flow and disengage itself. It was a living cataract. By dozens and hundreds they poured down from their crowded perch; and the more of them poured down, the more there were left of them. What a miracle of packing! They must have hustled and jostled one another as thick on the boughs as swarming bees that cling in a cluster round their virgin queen; while as for the ground beneath, it seethed and swelled like an ant-heap. For several minutes the pack rose from its camp, and fluttered and flowed down the steep side of the moor toward Wednesday Bottom, flying low in a serried mass, yet never seeming to be finished. They reminded me of those cunning long processions at the play, when soldiers and village maidens 


\section{A FLIGHT OF QUAILS.}

stream in relays from behind the wings, and disappear up the stage, and keep moving eternally. Only that is clever illusion, and this was reality.

"Lonely," people say! "No life on the hilltop!" Why, here was more life at a single glance than you can see in a whole long week in Piccadilly; an army on the march, making the heather vocal with the "wet-my-feet, wet-my-feet" of ten thousand voices!

But you must live in the uplands to enjoy these episodes. Nature won't bring them home to you in the populous valleys. A modest maid, she is chary of her charms; you must woo her to see them. She seldom comes halfway to meet you. But if you dwell by choice for her sake in her chosen haunts, your devotion touches her: she will show you life enough-rare life little dreamt of by those who tramp the dead flags of cities, where no beast moves save the draggled cab-horse. For you, the curlew 


\section{MOORLAND IDYLLS.}

will stalk the boggy hollows; for you, the banded badger will creep stealthily from his earth and disport himself at dusk among his frolicsome cublets; for you, the dappled adder will sun his zigzag spots, and dart his tremulous tongue, all shivering and quivering; for you, the turbulent quail will darken the ground in spring, or spread cloud-like over the sky on cloudless summer evenings.

And what poetry, too, in their sudden entrance on the scene, dropped down from heaven, one would think, as on Israel in the wilderness! Small wonder the marvelloving Hebrew annalist took those multitudinous birds for the subject of a miracle. But yesterday, perhaps, they were fattening their plump crops among the vine-shoots of Capri, the lush young vine-shoots with their pellucid pink tendrils; and to-day, here they are among the dry English heather, as quick and eager of eye as by Neapolitan fig-orchards. Swift of flight and 


\section{A FLIGHT OF QUAILS.}

patient of wing, they will surmount the Apennines and overtop the Alps in a single night; leave Milan in its plain and Lucerne by its lake when the afterglow lights up the snow on the Jungfrau; speed unseen in the twilight over Burgundy or the Rhineland; cross the English Channel in the first grey dawn; and sup off fat slugs before twelve hours are past, when the shadows grow deep in the lanes of Surrey. Watt and Stephenson have enabled us poor crawling men to do with pain and discomfort, at great expense, in the chamber of torture described with grim humour as a train de luxe, what these merry brown birds, the least of the partridge tribe, can effect on their own stout wings in rather less time, without turning a feather. If you watch them at the end of their short European tour from Rome to England at a burst, you will find them as playful and as bickering at its close as if they had just gone out for an evening constitutional. 


\section{MOORLAND IDYLLS.}

Quails are the younger brothers of the partridge group; but, unlike most of their kind, they are gregarious and migratory. They spend their winters in the south, as is the wont of fashionable invalids, and come northward with the spring, in quest of cooler quarters. Myriads of them cross the Mediterranean from Africa with the early sciroccos, and descend upon Calabria and the Bay of Naples in those miraculous flights which Browning has immortalized in "The Englishman in Italy." Quail-netting is then a common industry of the country about Sorrento and Amalfi; thousands of the pretty little gray-and-buff birds are sent to market daily, with their necks wrung, and their beautiful banded heads, "specked with white over brown like a great spider's back," all dead and draggled. Many of the flocks stop on during the season among the vineyards in Italy; but other and more adventurous hordes, tired of southern slugs and fat southern beetles, wing their way 


\section{A FLIGHT OF QUAILS.}

still further north, to Germany, Scandinavia, England, and Scotland. At one time they were far from uncommon visitors in our southern counties; but brick and mortar have disgusted them, and their calls are nowadays liker to angels' visits than in the eighteenth century. Yet a few still loiter through the winter in Devonshire or Kerry; while in summer they still reach to the Orkneys, Shetland, and the Outer Hebrides.

Beautiful as quails are, both to look upon and to eat, they are not personally amiable or admirable creatures. Their character is full of those piquant antitheses which seventeenth-century satire delighted to discover in the human subject. They are gregarious, but unsociable; fond of company, yet notoriously pugnacious; abandoned polygamists, with frequent lapses into the strictest monogamy; fighters destitute of the sense of honour; faithless spouses, but devoted, affectionate, and careful mothers. I fancy, too, they must have a wonderful 


\section{MOORLAND IDYLLS.}

instinct in the matter of commissariat, increased, no doubt, by ages of strategical evolution: for it can be by no means easy to find supplies for so large an army on the march; yet quails seem always so to time their arrival at each temporary stoppingplace as exactly to fall in with some glut in the insect-market. Only a few days before they came here, for example, not a beetle was to be seen upon the parched-up heath; but day before yesterday it rained insects, so to speak; and last night one could hardly take a step down the Long Valley without crushing small beetles underfoot, against one's will, by the dozen. The quails must somehow have got wind of the fact that there was corn in Egypt, be it by scent, or scouts, or some mysterious instinct; and here they are to-night, swarming up in their thousands, to enter into possession of their ancestral heritage. You should see them wage war on the helpless longicorn! I hope they will nest here, as it is amusing 


\section{A FLIGHT OF QUAILS.}

to watch them. Each little Turk of a husband keeps a perfect harem of demure brown hens, looking slily askance from the corners of their eyes, and watches over them close by with all the jealousy of a Mahmoud or a Sultan Soleyman. The rival who tries to poach on his lordship's preserves has, indeed, a hard time of it; he will retire, well pecked, from his rash encounter. Quails, in fact, are still in the Mohammedan stage of social evolution, while our more advanced and enlightened English partridges have attained already to a civilized and Western domestic economy. 


\section{VIII.}

\section{IN LEAFLESS WOODS.}

YES: these bare boughs, I take it, are not all pure loss. They have their consolations; they have their artistic and intellectual value. They show us, after all, the true inwardness of the tree; they enable us to realize, as none could otherwise do, the infinite diversity of architecture and ground-plan in the design and execution of the forest denizens. While dense masses of foliage clothe and obscure the boughs with their gay greenery we can gain but a rough idea of the underlying structure. But just as a Leonardo or a Luca Signorelli must needs pry beneath skin and muscle to discover the actual framework and bony supports of the body, so the lover 


\section{IN LEAFLESS WOODS.}

of the trees desires from time to time to catch some glimpse of the very limbs and joints of oak or maple-to get rid of the green covering in favour of the naked underlying reality. So only can one enjoy the delicate lissom twigs of the silver birch, etched in tender grey against the hard blue sky; so only can one observe the forked upright branches of the Lombardy poplar, like natural candelabra, in striking contrast with the long hanging boughs of the weeping-willow, divided and subdivided into pendulous twigs, and losing themselves at last in fine spray of living threads, like a wind-driven cataract. Every kind of forestdweller has thus its own special beauty of architectural plan; and every one of them can be realized in all its naked grace and variety of outline only when relieved of the glorious green weight that so richly concealed it.

And bare boughs are instructive, too, as well as beautiful. They suggest to one the 


\section{MOORLAND IDYLLS.}

endless vicissitudes and cataclysms in the history of growth; they show us how the knotted trunk acquires its final form, and by what course of evolution branch added to branch builds up at last the whole noble shape of the buttressed beech or the spreading horse-chestnut. Take, for example, our dear old friend the ash. In summer you can hardly discern through a canopy of green the outline of his bent boughs, curved downwards by their own weight of heavy feathery foliage, each leaf a little branch with numerous spreading leaflets. But when autumn comes, and the heavy leaves drop off one by one, you get revealed at once the peculiar beauty of his mode of growth-that delicious combination of angular and curved form which makes the ash the acknowledged king of the winter woodland. All the branches dip gracefully in a long arch towards the end, and then rise again with an abrupt curve; this hooked type of terminal bough being so distinctive and so well 


\section{IN LEAFLESS WOODS.}

marked an ashy feature that you can tell an ash by it afar off in its wintry nakedness as you whirl by in a train at a mile's distance, especially if it happens to be silhouetted against the sky on a bare ridge or hilltop. The growth of the oak, on the other hand, so gnarled and irregular, is quite equally characteristic; while the disposition of the buds soon reveals the fact that this very irregularity itself owes its origin in the last resort to a survival of the fittest among many abortive branches. For the oak tries, as it were, to grow symmetrically like a conifer; but frost and wind play such havoc with its delicate young shoots that it never succeeds in realizing its ideal, but grows habitually distorted against its will by external agencies.

Nor does our winter leave us wholly leafless. Even in England we have a fair sprinkling of native-born evergreens. And I really don't know that I would wish them more frequent; for nothing can be more 


\section{MOORLAND IDYLLS.}

monotonous, more sickly sweet, than the unvarying green of tropical forests; while the grateful contrast of drooping birch twigs or big-budded bare oak branches with the dark and sombre verdure of our northern Scotch firs, is in itself one of the chief charms of English winter. During the Tertiary period, indeed, our English woods were full of large-leaved evergreens of the southern types-camphors and cinnamons, and rhododendrons and liquidambars; but with the coming on of the Great Ice Age those lush southern forms were driven southward for ever, leaving us only the Scotch fir, the yew, and the juniper, with a few broader-leaved kinds of shiny evergreen, of which holly, ivy, and box are the most familiar examples. These, with the exotic laurels and aucubas, the daphnes and the laurustinuses, are quite enough to diversify pleasantly our northern scenery. Then our recent acquisitions of exotic conifers, like the Douglas pines, the sequoias, and the beautiful glaucous firs, "the 


\section{IN LEAFLESS WOODS.}

greenest of things blue, the bluest of things green," which now abound in plantations, have done much to redeem the surviving reproach of the glacial epoch.

Not that any of these plants are really evergreen in the stricter sense that most people imagine. All our foliage alike is, strictly speaking, annual, and all alike deciduous; but while oaks and beeches shed their dead leaves in our climate in autumn, pines, firs, and hollies retain theirs on the tree till the succeeding spring, and then let them drop quietly off, unperceived amid the pale glory of the fresh green foliage. The larch is a well-known example of a conifer which behaves in this respect like the oak or the birch; while its ally, the spruce fir, keeps on the dead or dying leaves through the winter months, and then shuffles them off unobtrusively as the new foliage develops. The evergreens get the advantage of utilizing any stray scrap of winter sunshine; but then they have to protect their living green 


\section{MOORLAND IDYLLS.}

material with a thick coat of glazed outer cells; the deciduous trees, on the other hand, withdraw all the living protoplasm in autumn into the live layer of the bark, drop the dead skeletons of the leaves on the ground, and utilize the protoplasm afresh for the formation of young leaves when spring comes round once more in due season. Nothing is lost; everything is economized, hoarded, and finally used up again. 
IX.

\section{A BUTTERFLY EPISODE.}

$\mathrm{HE}_{\mathrm{E}}$ was an airy, fairy orange - tip. He had just emerged from the chrysalis, and stood poised for a moment, like a hesitating Psyche, on the flat-topped blossoming branches of a big white cowparsnip. For the most part, he sat there, irresolute, plimming his untried wings, and half opening them tentatively from time to time, as if wondering to himself how the dickens they got there. And well might he wonder; for remember, he was bred a common green caterpillar. Never till this moment did it dawn across his mind that such a motion as flight could exist in the universe. So there he sat still, uncertain 


\section{MOORLAND IDYLLS.}

what strange change had come over him unawares. Six well-formed legs, in place of the creeping suckers on which he crawled in his youth; and what could these thin vans mean-these light and airy vans, that moved so dubiously on his soft woolly shoulders?

While his wings remained erect and closed, the under surface alone showed; and that was chequered green and white, like the flowers he sat upon. Indeed, so exactly did groundwork and insect harmonize with one another in hue and markings, that even a quick eye might easily have passed my orange-tip by unnoticed, were it not for the quivering movement of those uncertain wings, whose opening and shutting betrayed him, as I passed, to my scrutinizing survey. And this in itself was odd. For "How did he know," thought I- "he who till lately was but a small green grub, feeding on the lush leaves and stems of cresses-that he ought now 


\section{A BUTTERFLY EPISODE.}

to make straight, on his emergence from the chrysalis, for this white-flowered cowparsnip; which, indeed, is the favourite perching-place of all his race, and which effectually conceals him from the prying eyes of birds that fain would prey upon him, yet of whose very existence he, a crawling caterpillar, was till this moment ignorant? Surely that shows in his small brain some curious pre-existent picture, as it were, of this unknown cow-parsnip-a picture which enabled him to recognize it offhand when seen, and to steer for it at once with unerring instinct."

As I watched, the timid creature, feeling his wings at last, made up his tiny mind to spread those untried vans, and venture into the unknown on the undreamtof pinions. So he opened them wide, and displayed himself in his glory as a fullfledged orange-tip. His colours were still quite fresh, his feathery scales unspoiled by rain, or wind, or enemies. I gazed at 


\section{MOORLAND IDYLLS.}

him in delight, with sympathetic joy for his pure joy of living, as he unfolded those white wings, with their brilliant orange badge and their fringe of dark purple: For a second or two he darted off in the brilliant sunshine, rejoicing; he seemed to learn, as he went, to recall of a sudden some dim but recurring ancestral memory. All at once, as he fluttered somewhat doubtfully in mid-air, he caught sight from afar of a female brimstone. "Will he chase her?" I thought to myself; though, indeed, I knew well, had I chosen to recollect it, that inherited instinct is far too strong in these little creatures to admit for a moment such egregious errors. Our great Bashaw just glanced at her with unobservant eye; no gleam of recognition lighted up the tiny face. He passed on without one word; not a curve of the feeble flight; not a divergent pirouette of the orange-tipped pinions. Then a Clouded Yellow floated past, pursued by two rivals of her own swift-winged 


\section{A BUTTERFLY EPISODE.}

race. They are the fleetest of our butterflies. My orange-tip just glanced at them as who should say, "Strange that insects of taste should put up with such colouring. Why, she's almost pure white. I wouldn't look twice at her." The words had scarcely thrilled through his fatuous little brain when up loomed from windward a small yellowish butterfly, not wholly unlike himself: green and white underneath, fringed with black above, but without the orange spot which made my lord so attractive. In a second I recognized her: it was a female orangetip-a virgin female. But, quicker far than myself, her natural master had seen her and known her instinctively as the mate predestined for him. $\mathrm{Hi}$, presto! as I looked, all the world was one maze; the pretty things were at once in the thick of their courtship.

And what a courtship that was! How dainty! how ethereal! $\mathrm{He}$, rising on the breeze and displaying with pride his beautiful 


\section{MOORLAND IDYLLS.}

orange tips; she, coquetting and curvetting, dancing coyly through the air, now pretending to fly away, now affecting disdain, now returning to his side, now darting off on light wings just as he thought he had captivated that capricious small heart of hers. So they continued for ten minutes their dainty aërial minuet; and when last I caught sight of them they were still circling undecided above the sprays of wild rose in the hedgerow by the valley.

A familiar country sight. And yet, great heavens, what a miracle! For bethink you that that orange-tip was born and bred a small green-and-white caterpillar. $\mathrm{He}$ did not know, as you and I do, that his father and mother were orange-tip butterflies. He never saw or knew them. They were dead and gone before he emerged from the egg; and when he came out into the world, he met none of his own kind, save, it may be, some other small green-and-white caterpillars. His sole business in life was 


\section{A BUTTERFLY EPISODE.}

to gorge himself with cresses. At last, one fine day, when he had eaten his soul's fill, some inner impulse seized him. He began to transform himself, half unconsciously to his own mind, into a boat-shaped chrysalis. There he lay as in a mummy-case, melting slowly away into organic pulp, and growing again by degrees into a full-formed butterfly. All his organs changed; strange legs and wings budded out on him incontinently. Yet even when he emerged once more from the mummy-case, he had no intuitive knowledge of himself as a male orange-tip. Still less had he any distinct conception of the female of his species. But, as he floated about on his untried wings, he took no notice at all of any other butterflies, till the moment a mate of his own appeared upon the scene, and then he instantly and unerringly recognized her. The sole explanation of this marvel, it seems to me, lies in the fact that his nervous system has in it by inheritance a form or mould-if I 


\section{MOORLAND IDYLLS.}

may be allowed so material a metaphorinto which the image of his own kind and of his own mate falls and fits exactly. The moment that mould is completely filled and satisfied, the creature that fills it he loves as instinctively as Miranda loved Ferdinand, the first human being she had ever beheld save her father, Prospero.

And what is thus true of the butterfly is true, I believe, mutatis mutandis, of all of us. On the human brain there is impressed by anticipation a blank form or model of the human face and the human figure. Our central type of hurnan beauty is thus found for us by nature and ancestral experience: the nearer a man and a woman approach to that central type, the more beautiful, on the average, other things equal, do normal judges consider them. I do not doubt, of course, that many other and more general elements come in to complete the developed concept. White teeth, rosy cheeks, bright eyes, delicate curves, have of themselves a 


\section{A BUTTERFLY EPISODE.}

certain intrinsic and universal æsthetic value as colour and lustre, as shape and softness. But dainty pink is not so beautiful on the nose as on the cheeks or lips; nor are curves as desirable in the lines of the spine as in the external contour. Indeed, even expression itself has its stereotyped value; for a baby in arms will smile responsive to a smile from its nurse, and will cry at a frown, independently of experience. 


\section{$\mathrm{x}$. \\ THE FROZEN POND.}

THE pond on the moor is frozen over. What an epoch in the history of all its inhabitants! For they are not mostly long-lived creatures, these pond-dwellers; a summer forms an appreciable part of their short existence. Theirs is but a precarious life at the best of times; they have always to steer close between the Scylla of drought and the Charybdis of freezing. Half their days are spent in enforced seclusion. In the summer the pond, which is their universe, is apt to dry up and fail them ; in winter it stands its even chance of freezing solid and entombing them. To meet these two extreme contingencies, all the world of the pond has had 


\section{THE FROZEN POND.}

to accommodate itself to the possible chances of its fickle environment. The newts, for example, come here to breed every spring. They must needs do so, indeed, because their young have gills like a salmon or a herring, and can only breathe in their earlier stages the diffuse oxygen held in suspension in water. Newts, in fact, start in life as fish, but develop, half-way through, into lizard-like animals with lungs and legs, because of the annual drying up of their native waters. All higher life, indeed, was originally aquatic; it is only just because ponds dry up in summer that the ancestors of beasts and birds and reptiles ever ventured on dry land, at first for a brief excursion, and afterwards for a permanence. We are all in the last resort the descendants of amphibians. There are two kinds of newt in this pond, each with its own peculiar plan for meeting the difficulty of winter quarters. The great crested newt, who is the most confirmed water-haunter of the two, 


\section{MOORLAND IDYLLS.}

retires to the mud at the bottom of the pond in late autumn, and there lies torpid as long as the frost lasts, returning to the surface to breathe when the weather improves again. But the smaller newt, a more adventurous soul, goes ashore in summer, when the pond dries up, and stops there for the winter, lurking in long grass at the bottoms of ditches, or hiding in caves and damp vaults or cellars.

There are no fish in the pond, of course, because it is not permanent; it dries up in August. But there are frogs and tadpoles by the thousand in due season; and, what is odder still, the frogs are there now, though you cannot see them. Indeed, frogs and newts are merely slight variations on the fishy type, evolved to meet this very want and to fill this very place in the economy of nature: practically speaking, they are fish which turn at last into terrestrial reptiles. During the earlier spring days, when the ponds are full, the parents lay their spawn 


\section{THE FROZEN POND.}

among the sunk leaves of water-weeds; and soon the tadpoles emerge from their jellylike eggs, and swarm at the edge in a seething black mass of bustling and jostling life. Then, as the pond gets low, and breathing becomes difficult, they proceed by degrees to drop their gills, and develop the rudimentary swim-bladder into a pair of true lungs. Soon four weak little legs with sprawling fingers bud out at their sides; and, hi, presto! they hop or crawl ashore as full-fledged air-breathers. At this point grave differences appear between them. The newts retain their tails through life, but the more advanced frogs drop or absorb theirs, and assume the shape of thoroughgoing land animals. In winter, however, the frogs return once more to the pond, and bury themselves in the oozy mud at the bottom, often huddled together in closepacked groups, for warmth and company. At first sight you might think they would be warmer on dry land; but this is not so, 


\section{MOORLAND IDYLLS.}

for they have little animal heat of their own, being cold-blooded creatures, and they would therefore get frozen whenever the surface temperature fell below freezing-point. But the pond seldom or never freezes solid; in other words, the degree of cold at the bottom never goes down to freezing; and so the frogs are comparatively safe in the mud of the bed. If you dig in the ooze in winter, you may turn up whole spadefuls of frogs and great crested newts in certain cosy corners, lying torpid and half dead, but waiting patiently for the returning sun of spring to warm them. So that even the frozen pond has a great deal more life in it than the casual townsman would at first imagine.

As for the snails and beetles, and other small fry of the pond, they mostly retire, like their enemies the frogs, to the depths for protection. The summer is their life; winter to them is merely a time to be dozed through and tided over. Many of 


\section{THE FROZEN POND.}

the shorter-lived kinds, indeed, die out altogether at the first touch of autumn, leaving only their eggs or their pupæ to represent them through the cold season. In these cases, therefore, we might almost say that the species, not the individual, lies dormant through the winter. It ceases to exist altogether for the time, and is only vouched for by the eggs or spawn, so that each generation knows nothing by sight of the generation that preceded it.

But when spring comes round again, there is a sudden waking up into spasmodic activity on the part of the pond and all its inhabitants. The season has set in, and life is to the fore again. The greater newt, in imitation of the poet's wanton lapwing, "gets himself another crest," and adorns his breast with brilliant spots of crimson and orange. The mating proceeds apace; frogs pair and spawn; the water swarms once more with layer upon layer of wriggling black tadpoles. Now the 


\section{MOORLAND IDYLLS.}

great pond-snail floats at the top, and lays its oblong bunch of transparent eggs; now the water-crowfoot flowers; the diver beetles disport themselves amain; strange longlegged beasts that walk the water like insect Blondins, begin to stalk the surface on their living stilts ; and dancing little "whirligigs," who skim the pond, coquette and pirouette in interlacing circles. All nature is alive. Winter is forgotten; eating and drinking, marrying and giving in marriage, are the order of the day in pond and hedgerow. Then the crested newt proceeds to devour his smaller relative, and the tadpole to elbow his neighbour out of existence; and all goes merrily as wedding bells in the world of the pond-till winter comes again. 


\section{XI. \\ THE GNARLED PINE-TREE.}

MORE than once in these papers I have mentioned, as I passed, the wind-swept and weather-beaten Scotch fir on which the night-jar perches, and which forms such a conspicuous object in the wide moorland view from our drawing-room windows. I love that Scotch fir, for its very irregularity and rude wildness of growth; a Carlyle among trees, it seems to me to breathe forth the essential spirit of these bold free uplands. Not that any one would call it beautiful who has framed his ideas of beauty on the neatness and trimness of park-like English scenery; it has nothing in common with the well-grown and low-feathering 


\section{MOORLAND IDYLLS.}

Douglas pines which the nursery gardener plants out as "specimen trees" on the smooth velvety sward of some lawn in the lowlands. No, no ; my Scotch fir is gnarled and broken-boughed, a great gaunt soldier, scarred from many an encounter with fierce wintry winds, and holding its own even now, every January that passes, by dint of hard struggling against enormous odds with obstinate endurance. Life, for it, is a battle. And I love it for its scars, its toughness, its audacity. It has chosen for its post the highest summit of the ridge, where northeast and south-west alternately assault it ; and it meets their assaults with undiminished courage, begotten of long familiarity with fire and flood, with lightning and tempest.

Has it never occurred to you how such a tree must grow? what attacks it must endure, what assaults of the evil one it must continually fight against? Its whole long life is one endless tale of manful struggle and dear-bought victory. What survives 


\section{THE GNARLED PINE-TREE.}

of it now in its prime-for it is still a young tree, as trees go on our upland-is at best but a maimed and mutilated relic. From its babyhood upward it has suffered, like man, an eternal martyrdom. It began life as a winged seed, blown about by the boisterous wind which shook it rudely adrift from the sheltering cone of its mountaincradled mother. Many a sister seed floated lightly with the breeze to warm nooks in the valley, where the tree that sprang from it now grows tall and straight, and equally developed on every side into a noble Scotch fir of symmetrical dimensions. But adventures are to the adventurous; you and I, my tree, know it. You were caught in its fierce hands by some mighty sou'wester, that whirled you violently over the hilltop till you reached the very summit of the long straight spur; and there, where it dropped you, you fell and rooted in a windswept home on a wind-swept upland. Your growth was slow. For many and many a 


\section{MOORLAND IDYLLS.}

season your green sprouting top was browsed down by wandering cattle or gnawing rabbits ; you had some thirty rings of annual growth, I take it, in your stunted rootstock, just below the level of the soil, before you could push yourself up three inches towards the free and open air of heaven. Year after year, as you strove to rise, those ever-present assailants cropped you close and stunted you; yet still you persevered, and nathless so endured, till, in one lucky season, you made just enough growth, under the sun's warm rays, to overtop and outwit their continual aggression. Then, for a while, you grew apace; you put forth lush green buds, and you looked like a sturdy young tree indeed, with branches sprouting from each side, when, with infinite pains, you had reached to the height of a man's shoulder.

But your course was still chequered. Life is hard on the hilltops. You had to stand stress and strain of wind and weather. Like 


\section{THE GNARLED PINE-TREE.}

every other tree on our open moor, I notice you are savagely blown from the southwest; for the south-west wind here is by far our most violent and dangerous enemy, blowing great guns at times up the narrow funnel-shaped valleys, and so much more to be dreaded than the bitter north-east, which is elsewhere so inhospitable. "Blown from the south-west," we say as a matter of course in our bald human language; and so indeed it seems. I suppose most casual spectators who look upon you now really believe it is the direct blowing of the wind that so distorts and twists you. You and I know better. We know that each spring, as the sap rises in your veins, you put forth afresh lush green sprouts symmetrically from the buds at your growing points; and that if these sprouts were permitted to develop equally and evenly in every direction, you would have grown from the first as normally and formally as a spruce-fir or a puzzlemonkey. But not for us are such joys. 85 


\section{MOORLAND IDYLLS.}

We must grow as the tempests and the hail-storms permit us. Soon after you have begun each year to put forth your tender green shoots comes a frost-a nipping frost -whirled along on the wide wings of some angry sou'wester. We, your human neighbours, lie abed in our snug cottage, and tremble at the groaning and shivering of our beams, and silently wonder in the dark amid the noise how much of our red-tiled roof will remain over us by morning. (Five pounds' worth of tiles went off, I recollect, in last Thursday week's tempest.) But you, on your open hilltop, feel the fierce cold wind blow through and through you; till all the buds on your south-western face are chilled and killed; while even the others, more sheltered on the leeward side, have got nipped and checked, so that they develop irregularly. It is this lawless checking of growth in your budding and sprouting stage that really "blows you on one side," as we roughly state it. Only on your 
sheltered half do you ever properly realize the ground-plan of your nature. Your growth is the resultant of the incident energies. And that, after all, is the case with most of us; especially with the stormy petrels of our human menagerie.

Yet even to you, too, have come the consolations of love. "Not we alone," says the poet, "have yearnings hymeneal." Late developed on your cold spur, checked and gnarled as you grew, there came to you yet a day when your branches burgeoned forth into tender pink cones, with dainty soft ovules, all athirst for pollen; while on your budding shoots grew thick rings of rich stamens, that flung their golden powder adrift on the air with a lavish profusion right strange in so slenderly endowed an economy. But it is always so in nature. These gnarled hard lives, as people think them, are gilded brightest by the glow and fire of love; these poorest of earth's children are made richest at last in the 


\section{MOORLAND IDYLLS.}

holiest and best of her manifold blessings. It was nothing to you, I know, my tree, that the fire which swept over the heath some five years since charred all your lower branches and killed half your live bark; you had courage to resist and heart to prevail; and though those poor burnt boughs are dead and gone for all time, you still put forth smiling bundles of green needles above quite as bravely as ever. It was nothing to you that the great storm of last autumn rent one huge branch in twain, and tore off a dozen lesser arms from your bleeding trunk in a wild outburst of fury. The night-jar now sits and croons to you every evening in the afterglow from those self-same stumps; and struggling sheaths of young buds push through on the blown boughs that just escaped with their lives the fury of the tempest. No wonder the Eastern fancy sees curled dragons in the storms that so rend and assail us; but we like them, you and I, 


\section{THE GNARLED PINE-TREE.}

for the sake of the breadth, the height, the air, the space, the freedom. What matters it to us though fire rage and wind blow, so long as they leave us our love in peace, and permit us to spread our sheltering shade over our strong young saplings? The hilltops are free: the hilltops are open: from their peaks we can catch betimes some crimson glimpses of the sunrise and the morning.

So, now, my Scotch fir, gnarled and broken on the ridge, you know how I love you, and why I sympathize with you. 


\section{XII. \\ IVY IN THE COPSE.}

SEE what a beautiful creeping spray of ivy -dark green, with russet veins-from the ground beneath the copse here! How close it keeps to the earth! how exquisitely the leaves fit in with one another, like a living mosaic! That is why the ivy-leaf is shaped as we know it, with re-entrant angles, very abrupt and deep-lobed. The plant, as a whole, crawls snake-like over the ground in shady spots, or climbs up the face of stony cliffs, or mantles walls and ruins, or clambers boldly over the trunks of treeswhich last, though its most conspicuous, is not by any means its commonest or most natural situation. It is a haunter of the 


\section{IVY IN THE COPSE.}

shade; therefore it wants to utilize to the uttermost every inch of space and every ray of sunlight. So it clings close to the soil or to its upright support, and lays its leaves out flat, each occupying its own chosen spot of earth without encroaching on its neighbour's demesne, and none ever standing in the light of another. That shows one at once the secret reason for the angular foliage: it is exactly adapted to the ivy's habitat. All plants which grow in the same way, half trailing, half climbing, have leaves of similar shape. Three wellknown examples, each bearing witness to the resemblance in their very names, are the ivy-leaved veronica, the ivy-leaved campanula, and the ivy-leaved toad-flax. Or look once more at the pretty climbing ivy-leaved geranium or pelargonium, so commonly grown in windows. Contrast all these angular leaves of prostrate creepers with the heart-shaped or arrow-headed foliage of the upright twining or tendril- 


\section{MOORLAND IDYLLS.}

making climbers, such as convolvulus, black bindweed, black bryony, and bittersweet, and you will recognize at once how different modes of life almost necessarily beget different types of leaf-arrangement.

Nay, more. If you watch the ivy itself in its various stages, you will see how the self-same plant adapts its different parts from time to time to every variation in the surrounding conditions. Here in the copse, left to itself, as nature made it, it spreads vaguely along the ground at first with its lower branches, developing small leaves as it goes, narrow-lobed and angular, which are pressed flat against the soil in such a way as to utilize all possible air and sunshine. They cover the ground without mutual interference. And they are evergreen, too, so as to make the best of the scanty light that struggles through the trees in early spring and late autumn, while the oaks and ashes are all bare and leafless. But the main stem, prying about, soon finds out for itself 


\section{IVY IN THE COPSE.}

some upright bank or trunk, up which it climbs, adhering to its host by the aid of its innumerable short root-like excrescences. Here its foliage assumes still the same type as on the ground, but is not quite so closely appressed to the support, nor yet so sharply angular. The mode of the mosaic, too, has altered a little to suit the altered circumstances; the leaves now stand out more freely from the stem, yet in such a way as not to interfere with or overshadow each other. By-and-by, however, the ivy, as it grows, reaches the top of the bank, or some convenient flowering place on the friendly trunk; and then it begins to send up quite different blossoming branches. These rise straight into the air, without support on any side; unlike the creeping stems, they are stout enough and strong enough to stand alone-to bear their own weight and that of the prospective flowers and berries. Besides, they wish to be seen from all sides at once, so as to attract from 


\section{MOORLAND IDYLLS.}

far and near a whole circle of amicable birds and insects. And now observe that on these upright flowering branches the shape of the leaves changes entirely, so that you would hardly recognize them at first sight for ivy. They stand round the branch on all sides equally, and therefore have no longer any need to fit in and dovetail with one another. Each leaf is now somewhat oval in form, though sharply pointed; there are no more lobes or angles; and the outline as a whole is far fuller and usually unbroken. Yet they still avoid standing in one another's light, and are so arranged in spirals round the stem as to interfere as little as possible with one another's freehold.

The little yellowish-green flowers which top these branches appear in late autumn. They are not particularly conspicuous, and their petals are insignificant; yet they distil abundant honey on a disk in the centre, and they breathe forth a curious half-putrescent 


\section{IVY IN THE COPSE.}

scent, which seems highly attractive to many carrion flies and other foul feeders. Hence you will find that butterflies seldom or never visit them; but they are frequented and fertilized by hundreds of smaller insects, for whose sake the copious honey is stored on the open disk, where it is easily accessible to even the stumpiest proboscis. Ivy, in short, is a democratic flower: it lays by no rich store of secret nectar in hidden recesses, like the honeysuckle or the nasturtium, where none but the Norman-nosed aristocrats of the insect world can reach it; it is all for the common plebs. "A fair field and no favour" is the motto it acts upon. When the berries have been thus fertilized, they lie by over winter, slowly ripening and swelling, to blacken at last in the succeeding summer. The ripe fruit is then eaten by birds, such as hawfinches and certain of the thrush tribe, which disperse the hard nut-like seeds undigested. Black or dark blue are rare colours for flowers, 


\section{MOORLAND IDYLLS.}

but common for fruits; partly perhaps because birds are less fond of bright reds and yellows than the æsthetic insects; but partly also because such dusky hues are readily seen on a tree or bush against the snows of winter, the grey brown of late autumn, or the delicate wan green of early spring foliage. 


\section{XIII.}

\section{A DESPERATE STRUGGLE FOR LIFE.}

Alas, alas! most of the pretty white foxgloves we planted out by the boggy hollow just below the tennis-lawn have come to nothing. The heather and bracken of the moor have outgrown them and throttled them. They made a hard fight for life, in their petty Thermopylæ--one or two of them, indeed, are still battling with inexhaustible courage against the countless hordes of sturdy natives that choke and overshadow them; but die they must in the end, unless I step in betimes as earthly providence to thin out the furze and enrich the niggard soil for the struggling strangers. They 


\section{MOORLAND IDYLLS.}

remind me of the Pilgrim Fathers in Massachusetts. Foxgloves, you know, cannot compete with ling or Scotch heather on its native heath. They are denizens of a deeper and richer mould, growing generally on fat wayside banks or in the ditches by hedgerows - always the wealthiest and most luxuriantly manured of any wild places, because there birds perch, and wild animals take refuge, and snails and beetles die, and robins perish, that hedgerow weeds may batten on their decaying bodies. The hedge, in point of fact, is the main shelter and asylum for beasties great and small in our workaday England. There the hedgehog skulks, and the field-mouse hides, and the sparrow builds her nest, and the slowworm suns himself; there the rabbit burrows, and the thrush sits mocking, and the dormouse dreams, and the lizard lies in wait for the dancing midges. All the waste richness of the field finds its rest at last by the roots of the whitethorn, to reappear in 


\section{A STRUGGIE FOR LIFE.}

due time as red campion and herb-robert, as faint-scented may and tall military spikes of purple foxglove.

But when you sow or transplant these lush herbs of the hedgerow on to the bare and open heath, they come into competition at once with other and far hardier upland bushes. The plants of the moor are indeed unlike such pampered odalisques of the deep banks and rich lowlands. Stern children of the heights, their stems are hard and wiry, their leaves small and dry; their flowers feel like tissue-paper; their growing shoots have none of that luxuriant tenderness, that translucent delicacy, which characterizes the long sprays of hedgerow dogrose and hedgerow bramble. All is arid and parsimonious, as in some Highland cottage. Our daintily bred foxgloves, decayed gentlewomen, stunted and dwarfed in that inhospitable soil, can scarce find nutriment in the thirsty sand to send up a feeble parody of their purple spikes; in long droughts they droop 


\section{MOORLAND IDYLLS.}

and fail for lack of a drop of water. You must make a deep pocket of garden mould in the midst of the heath if you want them to thrive; and even then, unless you keep constantly cutting down the heather and gorse about them, they are overtopped and outlived by the native vegetation.

To dwellers in towns, that mere phrase, "the struggle for life among plants," seems a quaint exaggeration. They cannot believe that creatures so rooted and so passive as plants can struggle at all for anything. The pitched battles of the animals they can understand, because they can see the kestrel swooping down upon the linnet, the weasel scenting the spoor of the rabbit to his burrow. But the pitched battle of the plants sounds to them but a violent metaphor, a poetical trick of language, a notion falsely pressed into the service of the naturalist by some mistaken analogy. In reality, those few of us who have fully read ourselves into the confidence and intimacy 


\section{A STRUGGLE FOR LIFE.}

of the beautiful green things, know well that nowhere on earth is the struggle for life so real, so intense, so continuous, so merciless as among the herbs and flowers. Every weed in the meadows, every creeper in the woodland, is battling for its own hand each day and all day long against a crushing competition. It is battling for food and drink, for air and sunlight, for a place to stand in, for a right to existence. Its rivals around are striving hard with their roots to deprive it of its fair share of water and of manure; are striving hard with their leaves to forestall it in access to carbonic acid and sunshine; are striving hard with their flowers to entice away the friendly bee and the fertilizing beetle; are striving hard with their winged or protected seeds to anticipate the vacant spots on which it fain would cast its own feeble offspring. A struggle for the Hinterland goes on without ceasing. The very fact that plants can hardly move at all from the spot where they grow makes 


\section{MOORLAND IDYLLS.}

the competition in the end all the fiercer. They are perpetually intriguing among stones and crannies to insinuate their roots here, and to get beforehand on their rivals with their seedlings there; they fight for drops of water after summer showers, like the victims shut up in the Black Hole of Calcutta ; they spread their leaves close in rosettes along the ground, so as to monopolize space and kill down competition; they press upward toward the sun so as to catch the first glance of the bountiful rays, and to grasp before their neighbours at every floating speck of carbonic acid.

This is no poetic fancy. It is sober and literal biological truth. The green fields around us are one vast field of battle. And you can realize it at once if you only think what we mean by a flower-garden. We want to induce peonies and hollyhocks and geraniums and roses to smile around our houses, and what do we do for them? We " make a bed," as we say; in other words, 


\section{A STRUGGLE FOR LIFE.}

we begin by clearing away all the stouter and better-adapted native competitors. Go, dock and thistle; go, grass and nettle! We will have pansies here, and sweet-peas, and gilly-flowers! So we root them all up, turn and break the stiff clods, put in rich leaf-mould, manure it from the farmyard, and plant at measured distances the components of our nosegay. Tall white garden lilies take the place of knotweed; the larkspur mocks the sky where the dandelion spread before its golden constellations. Yet even so, we have not permanently secured our end. Original sin reappears as ragwort and hawkweed. Every day or two we must go round and "weed the beds," as we say; the very familiarity of phrase and act blinds our minds to the truth that what we are really doing is to limit the struggle, to check the competition. We pull up here a shepherd's-purse and there a chickweed, that the Iceland poppies may have room to raise their black-capped buds, and that 


\section{MOORLAND IDYLLS.}

the groundsel may not steal all the light and air from our shrinking nemophilas. Relax your care for a week or two, and what then do you find? The goosefoots and couch-grasses have lived down the mignonette; the russet docks are overshadowing your white Japanese anemones. Abandon the garden for a year, and the native vegetation has avenged itself on the intruders in a war of extermination. The thistles have cut off the lilies-of-the-valley, as Israel cut off the Canaanites; not a spike remains of your sky-blue monkshood before the purple standard of the victorious burdocks. Here and there, it is true, some hardy perennial, some stout iris or sweetwilliam, armed with its sword-shaped foliage, will continue the unequal strife for a miserable year or two of guerrilla warfare, like Hereward Wake in the Isle of Ely; but sooner or later the stronger will win, and your garden will become a mere nursery of weeds, whose flying thistle-down 


\section{A STRUGGLE FOR LIFE.}

will invade and usurp the neighbouring meadows.

Plants, in point of fact, have more needs than animals; therefore, perforce, they struggle harder. The beasts require but food and drink; the herbs require from the soil water and nitrogenous matter for their roots; they require from the air, carbon, which is their true solid food, for their leaves; they need sunlight, which is the motive power, for their growth and assimilation; insects to fertilize them, birds or breezes to disperse their seeds. For all these they struggle ceaselessly among themselves; and the struggle is all the deadlier because it is carried on at such very close quarters. 


\section{XIV. \\ COLTSFOOT FLOWERS.}

Down by the streamlet in the Frying Pan, in the heavy clay soil of the bank, I see this morning the flower-scapes of the coltsfoot are lifting betimes their curious bent heads. Two days more, and they will star the bare earth with their golden blossoms. That is a sure sign that winter is over, the labourers will tell you, weatherwise in their ancestral lore; 'and, indeed, the coltsfoot is a prudent and a wary herb, which I have seldom known go wrong in its calculation of probabilities. It makes its own weather forecast, independently of the Meteorological Office, and it backs its opinion. As long as it thinks frost is likely to recur, it "lies low," like 


\section{COLTSFOOT FLOWERS.}

Br'er Rabbit; but as soon as it feels pretty confident the worst is past, and no more hard weather will come to nip it in the bud, it boldly sends up its leafless flower-stem, looking more like a shoot of asparagus than anything else, with which most people are familiar. I have never seen it make a serious mistake, even in the sunniest and most treacherous English spring weather.

Who gave it its wisdom?-to parody Mr. Swinburne. How did it come so well to time itself as the earliest among our conspicuous spring flowers? Well, coltsfoot is a composite, belonging to the same minor group as the common ragworts-its very leaf, indeed, being a good deal like some of the larger ragworts in type, especially those handsome exotics of the race, so much cultivated in greenhouses under the name of cinerarias. But living in cold northern climates, on the banks of streams, in deep clay soil, where it spreads most vigorously, it has learned by experience 


\section{MOORLAND IDYLLS.}

to accommodate itself to its environment. It did so, in fact, many thousand years before Mr. Herbert Spencer taught poor recent humanity that latter-day catchword. Growing in thickset places, by running water, where its own large leaves and those of its neighbours would overshadow and hide its dainty blossoms in the height of summer, it has acquired the odd trick of sending them up naked, on the naked clay, in very early spring, when they court and easily attract the attention of the first spring insects to visit and fertilize them. In order to do this it must lay by material the summer before, and that material the prudent plants bury deep out of harm's way, in their creeping underground rootstock. Owing to the dampness and chilliness of the clay, which suits its constitution best, coltsfoot hides its rootstock exceptionally deep in the earth, and this precaution affords it, on the whole, a safe protection alike against cold and against burrowing enemies. As long as the 


\section{COLTSFOOT FLOWERS.}

frozen earth remains chilly underneath, the buds make no stir; but as soon as the subsoil begins to rise in temperature to a very modest point the flower-heads grow apace from the buried material, exactly as hyacinths do from a bulb when placed in water in a slightly warm atmosphere. And such a raising of temperature in the subsoil is one of the surest signs that winter has spent itself.

The flower-stem of coltsfoot rises bare and leafless, save for a few small scales, such as one sees on asparagus; but it is thickly covered with a warm cottony wool, to keep out winter, and the buds are bent down so as to protect them at once from chill and from injury. Each stem terminates in a single pretty fluffy yellow flowerhead, composed of innumerable golden florets of two kinds-those of the ray very narrow and ragged, giving the entire head its characteristic tasselled appearance; while those of the central disk are much larger, 


\section{MOORLAND IDYLLS.}

and bell-shaped. The entire blossom looks like a dandelion at first sight to a careless observer; but when you come to examine it closely, it is a far more dignified and beautiful flower. The tone of its yellow is richer, yet mellower, and its fluffy little rayflorets have a Japanesque charm in their flowing looseness.

So long as the flowers continue to bloom, you see no leaves; whence it comes about that many people know well the blossoms of coltsfoot in spring, and the foliage in summer, without having the faintest idea that they belong to one another. But if you keep your eye on the place where the yellow stars arose, after the flowers have withered and the white heads have blown away in copious flights, their wee feathery fruitlets, you will see by-and-by some big broad angular leaves, very thick and noticeable, rising high into the air from the same buried rootstock in the self-same position. Few leaves are more remarkable, with their heart- 


\section{COLTSFOOT FLOWERS.}

shaped bases and their obtrusive angles; while the under side is thickly covered throughout with a cottony wool, loose, white, and abundant. They are big, because they overtop the other leaves about, and so gain free access to the air and sunshine. They have elbow-room to spread in. Their business (like that of all leaves) is to catch and eat carbonic acid, which the sunlight assimilates for them. For this reason they are green above, with a transparent skin, which skin forms a water-layer for absorbing the gas and conducting it to the living green tissue beneath, where it is duly digested and assimilated. But why the cotton below? Well, the upper and under surfaces of leaves perform in nature quite different functions. The upper side, which is thick and firm, eats carbonic acid and receives the incident sunlight to digest it; but the under side, which is looser and spongier, gives off vapour of water-transpires, as we say-by innumerable little mouths, which are its 


\section{MOORLAND IDYLLS.}

outward breathing-pores. Now, these pores must not be allowed to get clogged with dew; so in wet meadows and by river-banks, where everything reeks with dew from sunset till late in the succeeding morning, almost all the plants protect the breathing-pores on their under side by such an unwettable felt of thickly matted cotton. Meadow-sweet is a familiar English example, and so is a close relation of our coltsfoot, the butterbur. 


\section{XV.}

\section{A HEATHER EPISODE.}

I FLUNG myself on the heath outside the house just now, with my friend the Editor. He edits a London literary journal, and disbelieves in everything. He is critical and sceptical. When he inherits glory (as he surely must do in time, for his is the noblest and purest and best of souls at bottom, in spite of its gruffness), I believe he will gaze about him at the golden floor and the walls of chrysoprase, and murmur to himself, "Humph! Not all it's cracked up to be!" Yet he is as tender as a woman, and as simple as a child; though he has found out the fact that the world is hollow, and that the human doll is stuffed with sawdust. 


\section{MOORLAND IDYLLS.}

We lay beside a clump of tall flaming rose-bay-fire-weed, as they call it over yonder in America. There, in the great woodlands, on whose lap I was nursed, a wandering child of the primeval forest, you may see whole vast sheets of that flamboyant willow-herb covering the ground for miles on bare glades in the pinewood. Most visitors fancy it gets its common American name from its blaze of colour; and, indeed, it often spreads like a sea of flame over acres and acres of hillside together. But the prosaic backwoodsman gave it its beautiful title for a more practical reason: because it grows apace wherever a forest fire has killed out and laid waste the native vegetation. Like most of the willowherbs, it has a floating seed winged with cottony threads, which waft it through the air on pinions of gossamer; and thus it alights on the newly burnt soil, and springs up amain after the first cool shower. Within twelve months it has almost obliterated the 


\section{A HEATHER EPISODE.}

signs of devastation on the ground under foot; only the great charred stems and gaunt blackened branches rise above its smiling mass of green leaves and bright blossoms, to tell anew the half-forgotten tale of ruin and disaster.

Here in England the rose-bay is a less frequent denizen, for it loves the wilds, and feels most at home in deep rich meadow bottoms unoccupied by tillage. Now, in Britain these conditions do not often occur since the Norman conquest; still, I have seen vast sheets of its tall pink pyramids of bloom at John Evelyn's Wootton; while even up here, on our heathery uplands, it fights hard for life among the gorse and bracken. Its beautiful spikes of irregular flowers, wide open below and tapering at the top into tiny knobs of bud, are among the loveliest elements in the natural flora of my poor three acres.

We were lying beside them, then, out of the eye of the sun, under the shadow of one 


\section{MOORLAND IDYLLS.}

bare and weather-beaten pine-tree, when talk fell by chance on the small brown lizards that skulk among the sandy soil of our hilltop. I said, and I believe, that the lizard population of the British Isles must outnumber the human by many, many millions. For every sandy heath is just a London of lizards. They pullulate in the ling like slum-children in Whitechapel. They were about us, I remarked, as thick as Hyde Park demonstrators; only, instead of demonstrating, they prefer to lie low and conceal their identity. The policeman hawks and the owls on night duty have taught them that wisdom-stern Draconian officers of nature's executive, who know no gentler punishment than the death penalty for the slightest misdemeanour.

The Editor smiled that sceptical smile which is the terror of young contributors of Notes on Novels. He rejected the lizards like unsuitable copy. He didn't believe in them. He doubted there were any on the 


\section{A HEATHER EPISODE.}

heath at all. He had walked over square miles of English moorland, but never a lizard had he seen, out of all their millions. Imagination, he observed, was an invaluable property to poets and naturalists. It was part of their stock-in-trade. He didn't seek to deprive them of it. As Falstaff says, a man may surely labour at his vocation.

I was put on my mettie. For once in my life, I did a rash thing; I ventured to prophesy. "If you wish," I cried, "I'll catch a lizard, and show you." The Editor's face was a study to behold. Phil May would have paid him ten guineas for the copyright. "As you like," he answered grimly. "Produce your lizards."

Fortune favours the brave. But I confess I trembled. Never before had I bragged; and now I wondered whether Fortune or Nemesis would carry it. 'Twas two to one on Nemesis. Yet the gods, as Swinburne tells us in "Les Noyades," are sometimes kindly. We lay still on the heather-still 


\section{MOORLAND IDYLLS.}

as mice - and waited. Presently, to my great and unexpected joy, a sound as of life ! - a rustling among the bilberry.bushes! One sharp brown head, and then another, with beady black eyes as keen as a beagle's, peeped forth from the miniature jungle of brake and cross-leaved heath in the bank beside us. I raised my lids, and looked mutely at the Editor. He followed my glance, and saw the tiny lithe creatures glide slowly from their covert, and crawl with heads held slyly on one side, and then on the other, into the open patch, on which we lay like statues. How they listened and looked! How they raised their quaint small heads, on the alert against the first faint breath of danger! I sat still as a mouse again, holding my breath in suspense, and waiting anxiously for developments. Then a miracle happened. Miracles do happen now and again, as once at Bolsena, to convince the sceptical. My hand lay motionless on the ground at my side. I would not have 


\section{A HEATHER EPISODE.}

moved it just then for a sovereign. One wee brown lizard, gazing cautiously around, crept over it with sly care, and, finding it all right, walked up my sleeve as far as the elbow. I checked my heart and watched him. Never in my life before had such a thing happened to me-but I did not say so to the sceptical Editor; on the contrary, I looked as totally unconcerned as if I had been accustomed to lizards taking tours on me daily from my childhood upward. "Are you convinced?" I asked, with a bland smile of triumph. Even the Editor admitted, with a grudging sniff, that seeing is believing.

And, indeed, there are dozens of lizards to the square yard in England, though I never before knew one of them to assail me of its own accord. I have caught them a hundred times by force or fraud among the heaths and sand-pits. The commonest sort hereabouts is the dingy brown viviparous lizard, which lays no eggs, but brings forth its 


\section{MOORLAND IDYLLS.}

young alive, and tends them like a mother. It is an agile, wee thing, that creeps from its hole or nest during the noontide hours, and basks lazily in the sun in search of insects. But let a fly come near it, and quick as lightning it turns its tiny head, darts upon him like fate, and crunches him up between those sharp small teeth with the ferocity of a crocodile. We have sandlizards, too, a far timider and wilder species; they bite your hand when caught, and refuse to live in captivity at the bottom of a flowerpot like their viviparous cousins. These pretty wee reptiles are often delicately spotted or banded with green; they lay a dozen leathery eggs in a hole in the sand, where the sun hatches out the poor abandoned little orphans without the aid of their unnatural mother. Still, they are much daintier in their colouring than the more domestic brown kind ; and, after all, in a lizard I demand beauty rather than advanced moral qualities. I may be wrong; but such is my 


\section{A HEATHER EPISODE.}

opinion. It is all very well to be ethical at Exeter Hall; but too sensitive a conscience is surely out of place in the struggle for life on the open moorland. 


\section{XVI. \\ THE CHRYSALIS YEAR.}

IN warm spots under hedges, I see, the first spring insects now begin to appear, timidly and tentatively, from the shelter of their cocoons. Some few of them, indeed, like the lady-birds, the wasps, and the bumblebees, have struggled through the winter in the winged or perfect form, having hibernated among warm moss or under the bark of trees in favoured situations. These adventurous kinds passed through their larval and pupal stages last year, and a tithe of them live on with difficulty through the winter frosts, to become the mothers and founders of fresh insect communities as April comes round again. But by far the 


\section{THE CHRYSALIS YEAR.}

greater number eat and grow as grubs or caterpillars through the summer months, and when autumn approaches turn into cocoons or chrysalides, to lie by for the winter in a snug retreat, well wrapped up in a warm silky or woollen coverlet, and protected underground from snow or hoarfrost. As soon as cold weather approaches, these prudent insects retire from public life, cease from active pursuits, melt themselves up into a sort of organic pulp, lose almost every distinguishable organ or feature, and remain dormant, in a state of indefinite protoplasm, which gradually takes shape again as moth, beetle, or butterfly. Mummies we sometimes call them, but they are not even mummies, for they lose almost entirely their form and limbs; they tide over the winter for the most part in an all but structureless mass, which yet encloses the potentiality of rebuilding in due course the shape and members of the ancestral insect. Slowly new limbs grow out within the protecting 


\section{MOORLAND IDYLLS.}

chrysalis case, wings bud from the side, and the grub or caterpillar changes by degrees into the totally unlike image of the beetle or butterfly. As soon as warmer weather sets in, the winged forms emerge with the first sunny day from their broken shell. I have seen nettle-butterflies abroad in a spell of genial warmth in the last week of January; a brimstone has been tempted forth to seek his lady-love on St. Valentine's Day; and fritillaries are abundant in early March sunshine. Lesser insects, whose names are enshrined in scientific Latin alone, often emerge from their mummy-cases even earlier than these familiar and conspicuous lepidoptera.

The moment they peep forth, lo and behold! they find the plant world, for its part, ready decked to greet them. The very same morning that sees the first butterfly and the first bee on the wing, sees also the first crocus opening wide its shining cup in the full sun to woo them. The 


\section{THE CHRYSALIS YEAR.}

brimstone is no sooner out than the coltsfoot and the celandine and the bulbous buttercup spread their gold to allure him. And has it ever struck you that the plants, no less than the animals, pass through the winter period in the chrysalis condition? This is no mere figurative flower of speech; it is the scientific statement of a real and profound analogy. During the summer months the leaves of the crocus, the tulip, and the hyacinth have been eating and laying by, exactly as the caterpillar did, to provide material for next year's flowering season. When winter blows cold, the leaves die down-the plant, as it were, retires underground into its bulb, like the caterpillar into the cocoon, and there remains, formless and organless, a mere pupa-like potentiality of future buds and blossoms. But when warm weather recurs, the bulb once more begins to germinate: it takes fresh form as a vigorous flower-head. Observe, too, that the flowering stem, like 


\section{MOORLAND IDYLLS.}

the winged stage of the insect, is the sexual epoch of the plant, an avatar told off, as the butterfly by the caterpillar, to produce the seeds which are the eggs of the species. In each case a certain definite period of time is passed in laying by material, in eating and storing only; then comes a quiescent epoch of rest and rebuilding; and this again is followed by a mature stage of marriage and reproduction. Notice, too, in either instance, that the reproductive stage is more beautifully formed and more attractively coloured than the mere accumulative and storing mechanism.

What is thus true of the crocus and of the butterfly is true, to a great extent, of all plants and animals in temperate or cold climates. They enter every winter into a chrysalis stage, from which in early spring they emerge once more, still more beautiful than before, freshly adorned for the mating and nesting period. Trees lose their leaves, and withdraw their protoplasmic and starchy 


\section{THE CHRYSALIS YEAR.}

material in a shapeless mass into the permanent tissues; but they hold it there, ready to manufacture it once more into bright green foliage and tasselled catkins, into blushing apple-blossoms, or tall spikes of horse-chestnut flower, or pink bloom of elms, "with the first spring sunshine. Squirrels hibernate; moles sleep away the dead of winter; frogs retire to the depths of ponds ; slugs bury themselves in the soil; dormice doze in well-lined crannies among the boles of hazels. Many species only tide over the cold weather, indeed, in the most potential form, as eggs or seeds; they are annuals, like the poppy or the aphides of roses. In such cases the whole race is represented for some months by its germs alone: one generation never sees or knows the existence of another. In other instances, somewhat higher, the species survives as pupa or as bulb, adult, no doubt, though in a relatively formless or indefinite shape, yet ready to come forth full-fledged and perfect 


\section{MOORLAND IDYLLS.}

at the first faint breath of returning summer. Still other kinds, again, struggle through as mature and fully formed insects, or birds, or mammals, and as evergreen trees or shrubs, though they live for the most part a life of low grade, and on accumulated materials. Nature is almost dormant in our zone through the winter months; life is then one vast and varied chrysalis. 


\section{XVII.}

\section{A SUMMER STROLL.}

My friend the Poet and I walk the world together on somewhat different principles. It is a fixed belief of his that illusion is far more beautiful than reality. He likes to see the distant hills through some dim veil of mist; he likes to believe the skylark feeds on dew and sunshine, and he is revolted when I explain to him, in spite of Shelley, the actual staples of its unromantic diet. To him, it seems, everything loses just half its beauty when he knows all about it. Analysis, he says, is destructive of pleasure. Only in an imagined and unrealized world can he find the pure elements that delight his fancy. 


\section{MOORLAND IDYLLS.}

But to me the actual world as it stands is beautiful. I love to descry the very contour of the hills; I love to watch from afar the saucer-shaped combes on the flanks of the South Downs, when the afternoon light floods and bathes them in its glory. Illusion to my mind is less lovely than reality. Nothing on earth seems more beautiful than Truth. I love to catch her face behind the clouds that conceal her.

And now it is the plain unvarnished Truth I am going to give you in this Moorland Idyll. I am going to tell you just what we saw to-day, without one episode or incident save what really occurred to us. I could not make that stroll more exquisite than I found it, if I tried till Doomsday. It was an idyll of real life. May many more so come to me!

We strayed together-the Poet, Elsie, Lucy, and myself-across the moor to Highfield, in search of strawberries. Highfield lies some two miles off, at the beginning of 


\section{A SUMMER STROLL.}

the valley; a lost old-world farm, in a dell of the moors, with a market-garden. You poor Londoners, when you go to buy strawberries, go to buy them prosaically at a commercial fruiterer's in a noisy street; but we moorlanders go with our basket in our hands to some lonely grange across the heather-clad upland. The first part of our walk lay high over the ridge, where the heath was burnt in the Jubilee year by the great fire; you can still plainly mark the point up to which the flames made a clear sweep of the heather, and the point where they left off, held in check by the beaters. For heather is really a forest-tree of some fifty years' growth; and the waste where the fire raged is still covered to this day with a shorter crop of young seedling gorse and ling and whortleberry, while the older vegetation unburnt beyond rises tall and bushlike. The blasted part, too, shows by far the finest and deepest purple of any; not because the flowers are really bigger or 


\section{MOORLAND IDYLLS.}

thicker, but because where the plants are still short the Tyrian purple of the Scotch heather is seen to greatest advantage; whereas, when they rise higher, the Scotch heather is overtopped by the bushier and coarser and taller-growing ling, with its somewhat insipid pale pink blossoms. The Poet thinks the fire makes the heath burn brighter. I think myself it keeps the ling lower.

Anyhow, that spur is one blaze of glory. Not a spot on the moor flares so splendid a purple. We passed through it, single file, by the narrow footpath, where the ling rises knee-high on either side, and the little brown lizards dart wildly to their holes at first sound of a footfall. Along the ridge, past the broom-bushes, now hanging with silvery pods, we continued on the path till we reached the white beam-tree. There the trail diverges a little suddenly to the left; a cock-pheasant broke with a shrill cry on the wing; his whirr as he rose startled the 


\section{A SUMMER STROLL.}

shallow valley. A wood-pigeon, alarmed at his alarm, flapped afield from the pinewood; the low cooing of his fellows from the larches beyond died away at the sound of his warning signal. Then we turned into the middle trail, where it dips towards the lowland.

All at once Elsie started, and gave a little cry-"A fox! a fox!" And, sure enough, there was one. He ran on before us, with his red brush depressed, fifty yards or more along the path on the open. Seldom have I caught a longer or clearer view of him unhunted in England. We were but ten yards behind, and had fairly surprised him. However, he took his discovery like a gentleman, and instead of skulking away to right or left, where the heath rose high, he ran on along the open, so as to give us a fine stare at him. Lucy, who is a visitor, unused to country ways, save as townsfolk know them, had never seen a live fox in the wild state before, and the incident charmed her. He was so lithe and 


\section{MOORLAND IDYLLS.}

red, and he ran so well, with his sharp head held low, and with the wild air of his species.

By the chestnut plantation, where a grassy little lane dips close between the trees, cropped and cut for hop-poles, we began to descend in real earnest to the valley. A rabbit just dashed across the sward on the slope of path; his twinkling white tail scarce betrayed him for a moment. Two hawks hovered above, but held off for fear of us. Rustlings in the fallen foliage beneath the sapling chestnuts to right and left gave sign of other rabbits, unseen, but scurrying burrow-ward. As we reached the open we disturbed a young covey of nursling partridges. Most of them disappeared after their prudent mother before we could catch a glimpse of them; but one poor little chick, belated and terrified, darted with its tiny half-naked wings erect in an agony of alarm in the opposite direction. It found covert in the chestnuts, its tiny heart throbbing. 


\section{A SUMMER STROLL.}

Alas, that it should have conceived at so early an age so justly unfavourable an idea of humanity!

Beyond the plantation we turned aside into a field, and oh! such a field! Have I words to picture it? It had been sown for grass; but no grass was there. "Bad season," says the farmer. "Thank Heaven for these slovenly farms," says the botanist. Blue cornflowers grew in it, thick as stars in heaven; and huge spikes of viper's bugloss as tall as a man's waist and more lovely than a turquoise. Who shall describe their hue, their form, their fashion? A great spotted stem, like a lizard's skin, green flecked with russet brown, and uncanny to look upon; on either side, long twisted spirals of red-and-blue blossoms, each curled like a scorpion's tail, very strange and lurid. The individual blossom is bright blue, when fully opened, with crimson stamens; the buds are deep red; the dead flowers dry violet. Altogether, a most 


\section{MOORLAND IDYLLS.}

weird and witch-like plant. I think one might use it with great advantage for incantations and sorcery. The Poet decided to try its effect next time he would rid himself of a discarded lady-love. We plucked great armfuls, and carried them along with us as far as Highfield. Other flowers were there, too, of less poetic interest-bright yellow corn-marigolds, and scented white campion; scarlet poppies by the score, with waving panicles of not a few tall grasses. We gathered of them all, and they stand before me now, gladdening my eyes as I write, in the coarse red pots of plain Hampshire earthenware.

They had no strawberries left, after all, at Highfield. We had our walk for nothing -if that be nothing! So we used the empty basket to carry back our trophies. But, returning by the lane, we filled our vacant arms once more with foxgloves; and the fox himself crossed our path for a second again at the selfsame turning, without 


\section{A SUMMER STROLL.}

seeking to reclaim them. Even the Poet admitted we had saved one day from Time's devouring maw. And that's how we live, up here in the moorland. 


\section{XVIII.}

\section{A MOORLAND FIRE.}

The frosts of last winter-that terrible, pitiless winter-killed down two-thirds of the gorse in England; and now that summer has come again, the dry brown branches stand bare and leafless in mute accusation in every moor and common in the country. Only an exceptionally hardy bush here and there puts forth, in a straggling and tentative fashion, a few timid shoots, or struggles ineffectually into feeble bloom on a protected bough or so. The bumble-bees wander about, disconsolate, like the hungry sheep in "Lycidas," and are not fed ; thousands and thousands of them have died this spring from so unexpected a failure of their staple 


\section{A MOORLAND FIRE.}

food-stuff. Honey and pollen have been quoted for the bees at starvation prices. We have natural selection here on a large scale in actual action before our very eyes: only the hardiest furze-bushes have this year survived the bitter frost; only the busiest, strongest, and most enterprising bumble-bees are now surviving the serious loss of their accustomed provender. Even heather has suffered much, which is a surprising fact, for heather belongs to a high sub-arctic type, that spreads in both its familiar British forms far north into Scotland, Scandinavia, and even Russia; while gorse, a shrub of much more southern and western nature, is rare in the Highlands, unknown in Norway or Sweden, and, in its smaller form, at least, incapable of enduring the severe winters of Germany to the east of the Rhine.

As a consequence of this dryness and deadness of the gorse, and to some extent of the heather-tops, heath fires have raged 


\section{MOORLAND IDYLLS.}

this spring in England with a fierceness and commonness I have never seen equalled. Every year, of course, especially about Eastertide, when furze and heather are normally at their driest, owing to the winter sleep, heath fires are frequent enough in times of drought on all sandy moorlands; but, as a rule, they cease altogether for the year when the gorse begins to burgeon and the heath to send up its long green summer shoots. As the sap mounts in the plants, and the spiky leaves grow green, the amount of moisture in stem and branches suffices to preserve the commons and moors from the danger of burning. This summer, however, the dead dry gorse-bushes catch a spark like tinder; and in the district where I live, among pines and heather, we have been nightly surrounded for many weeks by constant heath fires. Sometimes, perhaps, they are kindled of malice prepense, or out of pure boyish mischief; more often, however, I fancy they are due to mere human 


\section{A MOORLAND FIRE.}

carelessness in flinging down a match among the arid fuel. - A bicyclist's cigarette thrown lightly by the roadside, a labourer's pipe turned out casually upon the footpath-any such small thing is enough to set it going; and once lighted, the flames spread before the wind with astonishing rapidity, licking up with their fiery tongues whole leagues of dry gorse, and leaping with frantic glee and in crackling haste from bough to bough of the pines and hollies.

It is a strange sight, indeed, to see at night one of these lurid deluges, sweeping onward irresistibly, amid clouds of smoke and loud snapping of boughs, on its work of devastation. Terrible as it all is, it is yet beautiful while it lasts : the red sibilant flames, the fierce glare on the sky, the beaters beating it down on its leeward edge with branches of pine-trees, and silhouetted in black against the bright glow of the fire, all unite to make up a weird and intensely impressive picture. But to the beasts and 


\section{MOORLAND IDYLLS.}

birds whose home is on the moor, it is a cataclysm inexpressible, appalling, unthinkable. Lizards run before the advancing phalanx of flames in trembling terror till it catches them by the hundred, and calcines them as they run into fine white ashes; rats squeal from their holes in the bank with piteous screams of agony, as they are slowly roasted alive by the remorseless inundation; rabbits wait in silence in their stifling burrows, and are burned without one sound, for, true to their instincts, they prefer to meet death in their own scorching homes, rather than expose themselves to the dogs who follow every fire, and pounce with mad joy on hapless creatures that run for dear life from its devouring onslaught.

Next day-ah! next day-the area over which the flames have swept is pitiful to behold: blackened soil, charred bushes, naked boughs of burnt fir-trees. Among them, one morning, I saw a poor belated squirrel, exposed on the open, and picking 


\section{A MOORLAND FIRE.}

his way painfully over the smoking ground. Beneath his paws the loose black peat still smouldered sullenly. With dazed and doubtful steps, like a stupefied thing, he picked his way among the burning tufts. He had lost his mate, no doubt-his mate, and his little ones. The whole world he knew had been blotted out and effaced in one wild half-hour of indescribable terrors. Now he walked gingerly on tip-toe over the burning soil, as you and I might walk over the ashes of Mayfair if a fissure eruption had spread hot sheets of lava above the site of London. Just such a catastrophe to my squirrel was that awful night's work. He was stunned and mazed by it. I thought, indeed, for a time, he was half dead and roasted, till a dog ran after him ; then, quick as lightning, he darted up a charred tree, and looked down from the bare boughs upon his baffled pursuer. But none of the usual sly triumph was there in his look; the manifold experiences of that deadly night had 


\section{MOORLAND IDYLLS.}

killed all slyness and all archness out of him for ever. He wandered like a ghost among the blackened branches; his universe was gone; his life was blasted. I never saw a more pathetic sight, nor one that brought home to me in sadder colours the ruthlessness of nature. 


\section{XIX.}

\section{THE ARCADIAN DONKEY.}

ON the slope by the mountain-ashes, where the ridge curves downward into the combe with the plantation of young larch-trees, I met Peter Rashleigh leading his donkeyArcades ambo. "Jenny looks fat enough, Peter," I said with a nod as I passed on the narrow footpath; "and yet there isn't much grass up here for her to feed upon." "Lard bless your soul, sir," Peter answered with an expansive smile, "grass ain't what she wants. It don't noways agree with her. She's all the better with bracken and furzentops. Furzen-tops is good, like mobled queen." And I believe he was right, too. Jenny's ancestors from all time have been 


\section{MOORLAND IDYLLS.}

unaccustomed to rich meadow-feeding, and when their descendants nowadays are turned out into a field of clover they overeat themselves at once, and suffer agonies of mind from the unexpected repletion.

All the dwellers on our moor, in like manner, are poor relations, so to speak, as the donkey is to the horse. They are losers in the struggle for life, yet not quite hopeless losers; creatures that have adapted themselves to the worst positions, which more favoured and successful races could not endure for a moment. The naked Fuegian picks up a living somehow among snow and ice on barren rocks, where a wellclad European would starve and freeze, finding nothing to subsist upon. Just so on the moor; heather, furze, and bracken eke out a precarious livelihood on the sandy soil, where grasses and garden flowers die out at once, unless we artificially enrich the earth for them with leaf-mould from the bottoms and good manure from the farmyards. 


\section{THE ARCADIAN DONKEY.}

More than that, you may take it as a general rule that where grass will grow there is no chance for heather. Not that the heather doesn't like rich soil, and flourish in it amazingly - when it can get it. If you sow it in garden borders, and keep it well weeded, it will thrive apace, as it never throve in its poor native loam, among the stones and rubble. But the weeding is the secret of its success under such conditions. It isn't that the heather won't grow in rich soil, any more than that beggars can't live on pheasant; but grasses and dandelions, daisies and clovers, can easily give it points in such spots, and beat it. In a very few weeks you will find the lowland plants have grown tall and lush, while the poor distanced heather has been overtopped and crowded out by its sturdier competitors. That is the reason why waterside irises, or Alpine gentians, will grow in garden beds under quite different circumstances from those under which we find them in the state of 


\section{MOORLAND IDYLLS.}

nature; the whole secret lies in the fact that we restrict competition. Cultivation means merely digging out the native herbs, and keeping them out, once ousted, in favour of other plants which we choose to protect against all their rivals. In rich lowland soils the grasses and other soft succulent herbs outgrow such tough shrubs as ling and Scotch heather. But in the povertystricken loam of the uplands, the grasses and garden weeds find no food to batten upon; and there the heather, to the manner born, gets at last a fair field and no favour. It is adapted to the moors, as the camel is to the desert; both have been driven to accommodate themselves to a wretched and thirsty environment; but both have made a virtue of necessity, and risen to the cccasion with commendable ingenuity.

Everything about the heather shows longcontinued adaptation to arid conditions. Its stems are wiry; its leaves are small, very dry, uninviting as foodstuffs, curled under 


\section{THE ARCADIAN DONKEY.}

at the edge, and so arranged in every way as to defy evaporation. Rain sinks so rapidly through the sandy soil the plant inhabits that it does its best to economize every drop, just as we human inhabitants of the moorland economize it by constructing big tanks for the storage of the rain-water that falls on our roof-trees. Warping winds sweep ever across the wold with parching effect; so the heather makes its foliage small, square, and thickly covered by a hard epidermis, as a protection against undue or excessive dryness. It aims at being droughtproof. Its purple bells, in like manner, instead of being soft and fleshy, as is the case with the corollas of meadow-blossoms like the corn-poppy, or woodland flowers like the wild hyacinth, are hard and dry, so as to waste no water ; dainty waxen petals, like those of the dog-rose or the cherry-blossom, would wilt and wither at once before the harsh, dry blasts that career unchecked over the open moorland. Yet the heather-bells, 


\section{MOORLAND IDYLLS.}

though quite dead and papery to the touch, are brilliantly coloured to attract the upland bees, and form such wide patches of purple and pink as you can nowhere match among the largely wind-fertilized herbage of the too grass-green water-meadows. Upland conditions, indeed, always produce rich flowers. The most beautiful flora in Europe is that of the Alps, just below the snow-line; it has been developed by the stray Alpine moths and butterflies. Larger masses of colour are needed to attract these free-flying insects than serve to catch the eyes of the more business-like and regular bees who go their rounds in lowland districts.

Is not the donkey himself a product of somewhat similar conditions? Oriental in his origin, he seems to be merely the modern representative of those ancestral horses which did not succeed in the struggle for existence. Every intermediate stage has now been discovered between the true horses, with their flowing tails and silky coats, and the true 


\section{THE ARCADIAN DONKEY.}

donkeys, with their tufted tails and shaggy hair, the middle terms being chiefly found in the northern plains of Asia. Now, our horses, I take it, are the descendants of those original horse-and-donkey-like creatures which took to the grassy meadows, and so waxed fat, and kicked, and developed exceedingly; while our donkeys, I imagine, are the poor, patient offspring of those less lucky brothers or cousins which were pushed by degrees into the deserts and arid hills, and there grew accustomed to a very sparse diet of the essentially prickly and thorny shrubs which always inhabit such spots, just as gorse and heather inhabit our British uplands. That is why the donkey thrives so excellently to this day on thistles and nettle-tops : they represent the ancestral food of his kind for many generations. Certainly, at the present time, wherever we find horses wild it is in broad, grass-clad plains, or steppes, or pampas ; wherever we find donkeys, or donkey-like animals, wild, 


\section{MOORLAND IDYLLS.}

it is among desert or half-desert rocks, and on arid hillsides. It would seem as though the horse was in the last resort a donkey grown big and strong by dint of good living and free space to roam over; while the donkey, on the other hand, is in the last resort a horse grown small and ill-proportioned through want of good food and insufficient elbow-room. It is noteworthy that in small islands, like the Shetlands, small breeds of horses are developed in adaptation to the environment ; though, the food being still good pasture in a well-watered country, they retain in most respects their horse-like aspect. But a vengeance o' Jenny's case! I have wandered far afield from Peter Rashleigh's donkey, to have got so soon into evolutionary biology! 


\section{$\mathrm{XX}$.}

\section{A LIFE-AND-DEATH STRUGGLE.}

IT isn't often a man can stand at his own drawing-room window and be the interested spectator at a combat of wild beasts, where one antagonist not only conquers, but also fairly devours the other! Yet such Roman sport I have just this moment been unlucky enough to witness. Unlucky enough, I say, because the victor did not first kill and then eat his victim, as any combatant with a spark of chivalry in his nature would have done, but slowly chewed him up alive before my eyes, with no more consideration for the feelings of the vanquished than if the unfortunate creature had been a vegetable. I don't mean to pretend it was 


\section{MOORLAND IDYLLS.}

tiger versus cobra. The assailant was a thrush, the defender an earthworm. Now, thrushes, we all know, are sweet songsters when they have dined. Has not George Meredith hymned them, as Shelley the skylark? But if you want to see the poetry taken clean out of a thrush, just watch him as he catches and devours an earthworm! The poor unsuspicious annelid, feeling the joy of spring stir in his sluggish veins, comes to the surface for a moment in search of those fallen leaves which form the staple of his blameless vegetarian diet. No mole shakes the earth; the sod is fresh and moist; here seems a propitious moment for an above-ground excursion. So the earthworm pokes out his head and peers around him inquiringly; peers, I venture to say, blind beast though he be, because his method of feeling his way and exploring by touch is so human and inquisitive. But embodied Fate is on the watch, silent, keen-eyed, immovable; and 


\section{A LIFE-AND-DEATH STRUGGLE.}

no sooner does that slimy soul poke his nose above the ground than the thrush is upon him, quick and deadly as lightning. In one second the creature feels himself seized by one of his scaly rings, held fast in an iron vice, and slowly chewed piecemeal with the utmost deliberation. $\mathrm{He}$ wriggles and squirms, but all in vain; the thrush munches calmly on, now with this side of his bill, now that, drawing the worm ring by ring from the soil to which he desperately clings, and enjoying him as he goes with most evident gusto.

Both are intruders here. When first we came to our hill-top there were no thrushes and no earth-worms, no house-martins and no sparrows. But the building of one simple red-tiled cottage set up endless changes in the fauna and flora. A whole revolution was inaugurated over a realm of three acres. The house-martins were the first to come; they settled in before us. Ancestral instinct has taught them to 


\section{MOORLAND IDYLLS.}

know well that where a house is built there will be eaves to nest under, and people will inhabit it, who throw about meat and fruit, which attract the flies; and flies are the natural diet of house-martins. The sparrows came next; but the thrushes loitered longer. And the manner of their coming was after this fashion-

The powers that be had decided on a tennis-lawn. Previously nothing but heather and gorse spread over the hill-top; that is the native vegetation of this light sandstone upland. But in order to have tennis you must needs have a sward; so, much against the grain, we grubbed up wild heath enough to make a court, and sowed it for a tennis-lawn. Grass cannot grow, however, on such poor light soil as suits heather best, so we imported a few cartloads of mould and manure from a farm in the valley. With the mould came worms, who, finding a fair field, began to be fruitful and multiply and replenish the I 56 


\section{A LIFE-AND-DEATH STRUGGLE.}

earth with laudable rapidity. Few or no earthworms live in the shallow sand of the open moor; and, though a mole or two can just eke out a precarious living here and there in the softer and grassier hollows -I see their mounds every day as I cross the common-worms are not nearly abundant enough to tempt the epicurean and greedy thrushes from the shelter of the valley. For the mole, you see, goes out hunting underground on the trail of the earth-worm; but the thrush must needs depend upon the few stray stragglers which come to the surface morning and evening.

No sooner had worms begun to make castings on the lawn, however, than some Columbus thrush discovered a new world was opened to him. He and his mate took formal possession of the patch of green, which they hold as their own, using it regularly as a private hunting-ground. Every other tennis-lawn in the neighbourhood similarly supports its pair of thrushes, 


\section{MOORLAND IDYLLS.}

as (according to the poet) every rood of ground in England once "maintained its man." One of our neighbours has three lawns, terraced off in steps, and each has been annexed by a particular thrush family, which holds it stoutly against all comers. It is a curious sight in spring, when the nestlings are young, to see the parent birds going carefully over the groundsurveying it in squares, as it were-the cock a little in front, the hen hopping after him at some distance on one side, and making sure that not an inch of the superficial area remains unhunted. They eat many snails, too, breaking the shells against big stones; and they hunt for slugs now and then in the moist ditch by the roadway. While the nestlings are unfledged the industry of the elder birds is ceaseless; for they lay in early spring, and have to rear their young while food is still far from cheap or abundant. And, oh! but it is a gruesome sight to see them teaching the 


\section{A LIFE-AND-DEATH STRUGGLE.}

young idea of their kind how to tackle a worm-how to drag him from his burrow, ring after ring, as he struggles, to chop him up and mangle him till resistance and escape are absolutely hopeless, and then to devour him piecemeal. But in autumn the fierce heart of the carnivore softens; worms being then scarce, he condescends to berries. 


\section{XXI.}

\section{THE SHRIKE'S LARDER.}

YES; there is no denying it-this is a shrike's larder! The poor small beasts impaled here must have been hung iupon thorns by that cruelest of executioners. The hoard belongs, I think, to a red-backed shrike, whom I have seen more than once flitting through the trees of this copse on the hillside; for the great grey shrike has gone long since-he comes to us only as a winter visitor in the hardest seasons-while woodchats and smaller grey shrike hardly occur at all in this out-of-the-way district. Indeed, the red-backed bird is the only trueborn Briton of the entire family; he alone nests and rears his young here regularly. 


\section{THE SHRIKE'S LARDER.}

Butcher-birds, the gamekeepers call them, and well they deserve the title; for they catch and spit alive on the thorns of their larder all the bumble-bees and beetles, all the field-mice and robins they can swoop down upon and surprise from their bosky ambush. Cruel and ruthless birds, they seize whatever they can hold; but, instead of killing and eating their prey at once, they keep it deliberately alive as long as possible, on the stout thorn of a sloe-tree. Look at that poor shrew-mouse, for example, wriggling feebly on his stake, which the cunning bird has so managed to intertwine among the twigs as to make escape impos-. sible; he must have been hanging there in torture for a week by his look, but the shrike will not eat him till the last possible moment, unless so minded. And that poor lizard, again, with his wonderful tenacity of life; he may have been impaled for a fortnight, yet the skin on his ribs still rises and falls with a faint breathing action. 


\section{MOORLAND IDYLLS.}

More merciful than nature, we will put him out of his pain; though, after all, what good have we done by it? The shrike will catch another to replace him.

We talk of beautiful instincts and beautiful adaptations, so I suppose we may also talk of hateful ones; and this instinct of the shrike's is decidedly hateful. Yet such conduct is the rule in the world of animals : each species thinks only of its own comfort and pleasure; none takes the slightest heed of the pains of others. As Tennyson put it long ago-

"Nature is one with rapine, a harm no preacher can heal ;

The mayfly is torn by the swallow, the sparrow spear'd by the shrike,

And the whole little wood where I sit is a world of plunder and prey."

Assuredly no creature is worse in this respect than our red-backed butcher-bird. Yet he is a handsome wretch, for all that, especially in his beautiful and delicate spring plumage, when he first returns to us from 


\section{THE SHRIKE'S LARDER.}

his African winter quarters-chestnut and reddish brown above, melting into dainty grey-blue about the head and neck, not unrelieved by bold patches of pure black and pure white on the tail and forehead. Moreover, strange to say, he is an accomplished musician. But there is an ugly look about him, none the less, for all his fine song and all his fine feathers. He has a cruel, falcon-like expression of face; and any one who has ever seen him engaged in calmly spiking a harvest-mouse or a frog on a thick spine of blackthorn, without the faintest regard to his helpless victim's writhing, cannot fail to recognize the evil element in his eye, whenever he gives one the rare chance of viewing him.

Old-fashioned ornithologists used to think the shrikes were related to the birds of prey; and, indeed, they do somewhat resemble the smaller hawks in external features. But the likeness is purely superficial and adaptive-curved bill, strong 


\section{MOORLAND IDYLLS.}

talons, hard bristles on the beak, the keen eye of the hunter: it is the kind of similarity that must always exist among animals whose mode of life is closely similar. We know nowadays that structure depends upon habit, not habit upon structure. If you take to earning your living by rapine, you will acquire certain traits of strength and keenness inevitable in predatory forms; and that is why the shrikes, which are related by descent to the wrens and thrushes, have grown to resemble in external conformation the sparrowhawks and kestrels.

On the rare occasions when you do catch sight of a shrike, he is usually seated, half in ambush, on some perch in a tall hawthorn, or even openly on the telegraph-wires that cross a patch of likely hunting country. There he peers about and watches with his keen hazel eyes till mouse, frog, or lizard, bee, beetle, or dragon-fly, stirs in the meadow beneath him. Then, swift as thought, he swoops down upon his quarry from his 164 


\section{THE SHRIKE'S LARDER.}

invisible seat, not hovering and casting a telltale shadow like the hawk, but waiting his chance unseen under cover of the thicket. His favourite food, indeed, consists of bees and other soft-bodied insects; these he generally eats at once, returning forthwith to his perch and his peering. But if he catches any bigger prey, such as a frog, a field-mouse, a tomtit, or a partridge chick, he flies off with it to the larder, and there spears the wretched victim on a stout sharp spine, to devour it at his leisure. Even beetles and dragon-flies he will sometimes keep in stock, especially if his appetite is assuaged for the moment. Nevertheless, the butcher-bird is in the main an insecteater; he is commonest on warm sandy soils, like that of these Surrey moors, where bumble-bees and cockchafers abound, and enable him to make an easy living. Indeed, all beasts and birds are mostly regulated in their distribution by the abundance or scarcity of their food or prey. Shrikes 


\section{MOORLAND IDYLLS.}

have, doubtless, no native objection to cold thick clay, as such; but bees being rare on moist soils, and field-mice or lizards still rarer, the shrike learns to avoid damp, chilly bottoms as herbivores avoid a dry desert country. 


\section{XXII.}

\section{NESTS AND NO NESTS.}

STROLLING across the moor in the sunshine to-day, past the lonely pine where the nightjar sits crooning to his lady-love in the twilight, I came suddenly across his grey mate herself, and saw her flutter up sleepily in dazed surprise from the bare ground where she was sitting. As she flapped her mottled wings and sailed slowly away, like a blinking owl disturbed in the daytime, I noticed that I had lighted unawares upon her nest, or rather, her eggs, for she lays them on the open, without bed of any sort. I left them untouched, for I am no collector. A few minutes later, I came abreast of the low cliff where the sand-martins have 


\section{MOORLAND IDYLLS.}

established their twittering colony. The soft yellow sandstone that forms the cutting is honeycombed with their tunnels; and as I leaned on my stick and looked, I saw the busy brown birds gliding in and out, with their long curved flight, and carrying back mouthfuls of gnats and mayflies to their fledgelings in the burrows. It was beautiful to watch them swooping in great arcs over the gorse and bracken, and then darting straight, with unerring accuracy, to the mouth of their tunnels. They alight at the very door with. all the skill of born pilots, never missing or overshooting the mark by one inch, but steering upon it so truly that they look as though failure or miscalculation were impossible.

These two little episodes coming together set me thinking; 'tis a bad habit one indulges in when one walks too much alone in the open. In towns one doesn't think, because the shop-windows, and the horses, and the noise, and the people, and the 


\section{NESTS AND NO NESTS.}

omnibuses distract one; but in the country, one gives way a great deal too readily to what Plato calls the "divine disease" of thinking. I began to philosophize. How curious, I said to myself, that we have but five kinds of bird in England that hawk on the wing after insects in the open ; and of all those five, not one builds a proper respectable nest, woven of twigs and straws, like a sparrow or a robin! Every one of them has some peculiar little fancy of his own -goes in for some individual freak of originality. The night-jar, which is the simplest and earliest in type of the group, lays its eggs on the bare ground, and rises superior in its Spartan simplicity to such petty luxuries as beds and bedding. The swift, that ecclesiologically-minded bird, which loves the chief seats in the synagogue, the highest pinnacles of tower or steeple, gums together a soft nest of floating thistledown and feathers, by means of a sticky secretion from its own mouth, distilled in the 


\section{MOORLAND IDYLLS.}

last resort from the juices of insects. The swallow and the house-martin, again, make domed mud huts, and line them inside with soft floating materials, Finally, the sandmartin excavates with its bill the soft sandstone of cliffs or roadside cuttings, and strews a bed within for its callow young of cotton-grass and dandelion parachutes.

Why this curious variety among themselves, and this equally curious divergence from the common practice of bird-kind in general ? Clearly, thought I, it must bear some definite relation to the habits and manners of the birds which exhibit it. Let me think what it means. Aha, aha, eureka! I have found it! The insect-hawking birds are not a natural group; by descent they have nothing at all to do with one another. Closely as the swift resembles the swallow in form, in flight, in shape of bill, in habits and manners, we now know that the swift is a specialized woodpecker, while the swallow 


\section{NESTS AND NO NESTS.}

and the martins are specialized sparrows. (I use both words, bien entendu, in quite their widest and most Pickwickian evolutionary acceptation.) The swift and the night-jar belong to one great family of birds; the swallow, the house-martin, and the sandmartin to another. The likeness in form and in mode of flight has been brought about by similarity in their style of living. Two different birds of two different types both took, ages since, to hawking after flies and midges in the open air. Each group was thus compelled to acquire long and powerful wings, a light and airy body, a good steering tail, a wide gape of mouth, and a rapid curved flight, so as to swoop down upon and catch its petty prey unsuspected. So, in the long run, the two types which hawk most in the open, the swifts and the swallows, have grown so like that only by minute anatomical differences can we refer the remoter ancestry of one species to the woodpeckers and humming-birds, and the 


\section{MOORLAND IDYLLS.}

remoter ancestry of the other to the tits and sparrows.

How does their manner of life affect their mode of nesting, however? Indirectly, in this way. Birds that live largely off seeds and fruits and hard-shelled beetles, have hard short beaks to grind their food with, and sit much in thickets, scrub, or hedgerows. But birds that hawk on the wing after small soft flies must have wide soft bills, and a gaping mouth; they can hardly perch at all on trees or bushes, and their feet are too weak to be of much use for walking. Indeed, if a swift once alights on the ground, he can scarcely get up again, so difficult is it for the long wings to work in a narrow space, and so slight a power of jumping have the feeble little legs. Hence it follows that birds of the hedgerow type can readily build nests of twigs and straws, which they gather as they perch, or seek on the ground; and they are enabled to weave them with their hard bills and active feet; 


\section{NESTS AND NO NESTS.}

while birds of the hawking type cannot pick up sticks or gather straws on the ground, and have beaks quite unadapted for dealing with such intractable materials. The consequence is they have been compelled to find out each some new plan for itself, and to build their nest out of such stray material as their habits permit them.

The night-jar, a stranded nocturnal bird of early type, with very few modern improvements and additions, solves the problem in the easiest and rudest way by simply going without a nest at all, and laying her eggs unprotected in the open. Nocturnal creatures, indeed, are, to a great extent, the losers in the struggle for existence; they always retain many early and uncivilized ways, if I may speak metaphorically. They are the analogues of the street arabs who sleep in Trafalgar Square under shelter of a newspaper. The sand-martin, an earlier type than the swallow or the house-martin, burrows in sandstone cliffs, which are pre-human 


\section{MOORLAND IDYLLS.}

features, though man's roads and railways have largely extended his field of enterprise. But the house-martin and the swallow, later and far more civilized developments, have learned to take advantage of our barns and houses; they nest under the eaves; and being largely water-haunters, skimming lightly over the surface of ponds and lakes, they have naturally taken advantage of the mud at the edges as a convenient building material. Last of all, the soaring swift, the most absolutely aërial type of the entire group, unable to alight on the ground at all, has acquired the habit of catching cottony seeds, and thistledown, and floating feathers in his mouth as he flies, and gumming them together into a mucilaginous nest with his own saliva. The Oriental sea-swifts have no chance of finding even such flying materials among their caves and cliffs, and they have consequently been driven into erecting nests entirely of their own inspissated saliva, without any basis of down or 


\section{NESTS AND NO NESTS.}

feathers. These are the famous edible birds'-nests of the Chinese ; they look like gelatine, and they make excellent soup, somewhat thick and gummy. 


\section{XXIII.}

\section{THE CROUCH OAK.}

THE old Crouch Oak on Walford Green is one of the sights of Surrey. It raises its gnarled and hollow trunk in the centre of the Ploy-Field, an ancient common meadow, and though decayed in its heart, is reckoned still among the principal bounds of Ringmer Forest. Its girth at the height of a man's arms is over twenty feet. Beneath its spreading branches stands an upright stone of immemorial antiquity, which only the righteous wrath of a local archæologist succeeded in preserving a few years since from the modern desecration of a Jubilee inscription. This close combination of sacred tree and sacred stone is frequent 


\section{THE CROUCH OAK.}

and significant; it occurs all the world over, from Britain to the New Hebrides; it is found in India, in Syria, in Germany, in Ceylon, in civilized Rome, in barbaric New Guinea. Wherever the sacred tree spreads its brooding circle of welcome shade, there under its huge boughs the sacred stone bears witness to antique or still surviving rites of human sacrifice.

It is this, indeed, that gives our British Gospel Oaks their unique interest amid the public monuments of England. Alone among the temples of our old heathen faith they have outlived the overwhelming deluge of Christianity. In the south of Europe we have still the Parthenon and the columns of Pæstum to testify boldly to the older creeds. In the north, where temples made with hands were rarer, where art had not learned to raise such colossal piles as Karnak or Denderah, the sacred oak alone remains to us now as a lingering memorial of the cult of our ancestors. 


\section{MOORLAND IDYLLS.}

Even these, too, have been Christianized, in accordance with Gregory's well-known advice to Augustine. The holy sites of the ancient faiths, said the wise Pope, in his epistle, were still to be respected; but the demons who inhabited them were to be exorcised by the use of Christian symbols, and the temples were to be sanctified to Christian worship. In accordance with this policy, a figure of the cross was marked upon the bark of the old sacred tree in Walford Ploy-Field, which thus became known as the Crouch or Cross Oak; for the Latin crux came first into our language under the truer English form of crouch, and only assumed its later pronunciation of cross under northern influences. Similar Christianization of holy oaks, shire oaks, boundary oaks, Druid oaks, and other heathen temples or heathen termini, went on all over England; so that what were once Thunor's trees and Woden's trees, or still 


\section{THE CROUCH OAK.}

earlier, the sacred haunts of native Celtic deities, became in the end those "Gospel Oaks," under which, at the annual beating of the bounds, the priest stopped with his acolytes to read a few verses of St. Luke or St. Matthew. Sometimes, indeed, hardly more than the memory of some particular episode in the history of the sacred tree now survives, as at Addlestone, near Chertsey, where there is also a crouch oak, chiefly famous at present from a local tradition that Wickliffe once preached under its canopy of branches. But the older holy and even phallic virtue of this sacred trunk is proved by the fact that decoctions of its bark taken internally, after a wellknown and almost world-wide fashion, are still considered by the girls of the village to operate as a love-charm.

The history of these ancient trees, so far as we can reconstruct it from the piecemeal evidence, is picturesque and singular. Originally, I believe, they were planted as 


\section{MOORLAND IDYLLS.}

saplings over the barrow or tumulus of some barbaric chieftain; not a few of them, indeed - like the King's Oak at Tilford, near Farnham-still retain some title which recalls their royal or funereal origin. The sacred stone, which in every case seems once to have stood under their dense shade, was doubtless at first the standing-stone or gravestone of the buried chief; though later it probably served as an unhewn altar for the village sacrifices, like that offering of the lamb which till recent years was still torn to pieces on an anniversary festival in the Ploy-Field at Holne, in Devonshire. Every year, in point of fact, the people of each village used once to perambulate their bounds, as at the Roman Terminalia, and offer up at each holy tree and each terminus stone, which formed the main landmarks, a human sacrifice. The victims were usually boys-most probably captives from neighbouring tribes or villages; failing that, they were "bought with a price" within the tribe 


\section{THE CROUCH OAK.}

itself from their unnatural parents. Traces of these customs survive all the world over, while the practice itself is closely bound up with the worship of Terminus and other boundary spirits. In later and milder days, however, though the habit of beating the bounds survived, the incidents that accompanied it were considerably mitigated. The ceremony at first was essentially an exorcism, or driving of evil spirits beyond the village limits; and the boys seem to have been slaughtered as boundary guardians, in order that their ghosts might protect and maintain the local frontier. They were also scourged before being put to death, after a common superstition, so that their tears might act as a sympathetic rain-charm. But in later Christian days it began to be felt that to read the Gospels under the sacred oak of the boundary would sufficiently drive away all evil influences; and though the boys were still beaten at each terminus as a rain-charm, the meaning of the incident was 


\section{MOORLAND IDYLLS.}

so wholly forgotten that it was commonly interpreted as a means of impressing the boundaries on their memories-a foolish gloss of the usual fatuous eighteenth-century rationalizing type. Thus the Gospel Oak at Cheriton is now only remembered as the tree under which the Gospel was read at the perambulation of the bounds; the Crouch Oak at Addlestone has sunk into a prosaic legal boundary-mark of Windsor Forest ; and the Twelve Apostles at Burley, near Ringwood, now reduced to five, have been finally Christianized out of all recognition, so that I cannot even conjecturally reconstruct their original dedication to some ancient Celtic or Teutonic deities. 
XXIV.

\section{A SPOTTED ORCHIS.}

Like Mr. Chamberlain, I too am an orchidgrower. I own three acres (without a cow) on a heather-clad hilltop, and no small proportion of that landed estate is "down under orchids." Not that I mean to say the species I cultivate, or rather allow to grow wild, on my wild little plot would excite the envy. of the magnate of Highbury. They are nothing more than common English spotted orchids, springing free and spontaneous among the gorse and heather. But, oh! how beautiful they are! how much more beautiful than the dendrobiums and cattleyas, the flowering spiders and blossoming lizards of the rich man's hothouse! I 83 


\section{MOORLAND IDYLLS.}

How proudly they raise their tall spikes of pale bloom, true sultanas of the moorland! how daintily they woo the big burly bumble bees! how gracefully they bend their nodding heads before the bold south-west that careers across the country! They seem to me always such great regal flowers, yet simple with the simplicity of the untrodden upland.

Take a spike and look at it close; or, better still, grub it up by the roots with the point of your umbrella, and examine it all through from its foundation upward. It springs from two tubers, not unlike a pair of new potatoes to look at, but deeply divided below into finger-like processes. Those divisions it was that gave the plant its quaint old English title of "dead men's fingers "-for, indeed, there is something clammy and corpse-like about the feel of the tubers; while that "coarser name" to which Shakespeare alludes in passing, is due to their general shape, and is still 


\section{A SPOTTED ORCHIS.}

enshrined in the Greek word "orchid" which everybody now applies to them without thinking for a moment of its unsavoury meaning. But the two tubers are not of the same age. One is old and wilted; the other is young and fresh, and, as the advertisements say, "still growing." The first is last year's reserve-fund for this year's flowering stem; the second is this year's storehouse of food for next year's blossom. Thus each season depends for its flowers upon the previous year's income; the leaves, which are the mouths and stomachs of the plants, lay by material in due season; and the spike of bells proceeds from the tubers or consolidated reserve-fund as soon as the summer is sufficiently advanced for the process of flowering. Few plants with handsome heads or trusses of bloom, indeed, can afford to produce them upon the current season's income; therefore you will find that most large-flowered forms, like lilies, tulips, hyacinths, and daffodils, if they wish I 85 


\section{MOORLAND IDYLLS.}

to blossom early in the year, depend for their food-supply upon a bulb or tuber of last season's making. Only in the orchids, however, do you find this curious device of a pair of tubers at once side by side, one being filled and fed, while the other is being slowly devoured and depleted. By the end of the season the new tuber is rich and full to bursting, while the old one is withered, flaccid, and empty.

From the tuber, in early spring, start the pretty lance-shaped leaves-green, dappled with leopard spots of some deep brown pigment. The use and meaning of these beautiful spots on the glossy green foliage no one has yet deciphered; it remains as one of the ten thousand insoluble mysteries of plant existence. That is always so in life. We tell what we know; but what we know not, who shall count it or number it? Yet the flowers, after all, are the true centre of interest in the English orchid. Thirty of them in a spike, pale lilac or white, all I 86 


\section{A SPOTTED ORCHIS.}

starred and brocaded with strange flecks of purple, they rank among the most marvellous of our native flowers in shape and structure. The long spur at the back is the factory and reservoir for the abundant honey. The face of the blossom consists of a broad and showy lip, the flaunting advertisement to bee or butterfly of the sweets within; it is flanked by two slender spreading wings, above which a third sepal arches over the helmet-like petals. Beneath this hood, or dome, in the centre of the column, the club-shaped pollen-masses lie half concealed in two pockets, or pouchesdainty little purses, as it were, like fairy wallets-slit open in front for the bee's convenience. The base of the pollen-masses is sticky or gummy; and they are so arranged, of set purpose, in their pouches, that the moment the bee's head touches them, they cling to it automatically, by their gummy end, and are carried off without his knowledge or consent to the next flower 


\section{MOORLAND IDYLLS.}

he visits. But if you want to see exactly how this pretty little drama of plant life is enacted, you need not wait, as I have often done, silent on the heath for half an hour together, till some blustering bumble bee bustles in, all importance. It suffices for demonstration just to pick a spike and insert into the mouth of the honey-spur a stem of grass, which does duty for the bee's head and proboscis, when straightway "the figures will act," as they say on the pennyin-the-slot machines, and the pollen-masses will gum themselves by automatic action to the imaginary insect.

The reason for this curious and highly advanced device is that orchids are among the plants most absolutely specialized for insect-fertilization. Most species of orchid, in fact, can never set their seeds at all without the intervention of these flying "marriage priests," as Darwin quaintly called them. If left to themselves, the flowers must wither on their virgin thorn 


\section{A SPOTTED ORCHIS.}

unwed, and no seed be set in the twisted ovary. But when the bee goes to them in search of honey, the pollen-masses gum themselves to the front of his head, though just at first they point upward and inward. Then, after a short time, as he flies through the air, they contract in drying, and so point forward, in the direction in which he will enter the next flower he visits. This brings the pollen directly into contact with the sensitive cushion or pad of the ovary in the flower so visited, and thus results in the desired cross-fertilization. For the ovary, too, is gummy, to make the pollen stick to it.

A roundabout way, you think, to arrive, after all, at so simple a conclusion? Well, that is the habit of Nature. And again, bethink you, good, easy-going human being, how great are the difficulties she has to contend with, especially in the case of the plant creation. Put yourself in the orchid's place, and you will see the reason. For 


\section{MOORLAND IDYLLS.}

remember how absolutely fixed and limited are plants, each rooted to the soil in a single small spot, each tied by strict conditions of rock, and water-supply; and air, and wind, and sun, and climate, from which none can escape, try they all their hardest. The opposite sides of a road are to them as the two poles, one with a sunny and southward-looking bank, the other with a cold and forbidding northern aspect; so that what flourishes apace on the first would shiver and die of chill winds on the second. Remember, too, that, save in the mildest degree, plants have no power of spontaneous or independent movement; they cannot stir from their birthplace, were it but for a single inch, nor move their own limbs save as the wind may sway them. Creatures thus narrowly and inevitably bound down must needs take advantage of the power of movement in all other kinds, wherever it will benefit them. Hence the use plants make of insects as common carriers of 


\section{A SPOTTED ORCHIS.}

pollen; the use they make of birds as dispersers of seeds; the use they make of natural agencies, such as wind or stream, to waft winged thistle-down, to carry the parachutes of the dandelion and the willow, or to float the male blossoms of such waterweeds as vallisneria. Behold! I show you a mystery. The secret of the whole thing is that plants, being fixed themselves, must needs employ birds and insects as their Pickford vans-must rely on wind or stream for such casual services as wind or stream can easily afford them. Only in a few species can they effect anything like active movement for themselves, as one sees in the rooting runners of strawberries, or the wandering tubers of certain vagrant orchids, which spread far afield from last season's nesting-place. These are clever devices for securing fresh virgin soil- "rotation of crops," as the farmers put it. 
XXV.

THE ROOT OF THE MATTER.

Every Girton girl (vice Macaulay's schoolboy, retired from overwork)-every Girton girl knows that a well-conducted British oak "spreads its roots as far and wide through the soil beneath as it rears its boughs above toward the air of heaven." Every Girton girl is probably also of opinion that the British oak does this mainly or solely in order to fix itself by firm anchors in the soil-to withstand the battling winds and the constant pull of hostile gravitation. But what every Girton girl does not, perhaps, quite so confidently know is this-that, on the whole, the tips of the roots and the tips of the 


\section{THE ROOT OF THE MATTER.}

branches correspond roughly in situation with one another, so that if you were to unearth and expose the entire tree you would find it composed of two tolerably similar domes or hemispheres-one erect and aërial, and one inverted and earthbound, each occupying approximately equal areas, and each circumscribed by fairly equal circles.

Why should this be so? It is clear enough, of course, that in order to fasten a big tree firmly in the ground, it must have numerous large and strong foundations. But wherefore this approximate equality in the areas occupied by roots and frondage? The answer is, because every large tree forms a sort of umbrella, a domed roof or catchment basin for the rain that falls upon it; and it has always its own peculiar and admirably adapted arrangement for conducting all the water it intercepts to certain special spots or drinking-places in the ground, where it 


\section{MOORLAND IDYLLS.}

sets the roots, and especially the rootlets, or absorbent terminals, intended to soak that water up and convey it to the branches. If you stand under an oak-tree during a summer shower - a mode of passive scientific observation for which nature has afforded quite ample opportunities during the last few weeks-you will notice at once that the round mass of its foliage acts exactly like a huge umbrella, and conducts all the rain that falls upon its surface outward and downward towards the circumference of the circle. The drops that alight upon the central and tallest part of the tree are shed by the veined and channelled leaves till they fall off the tips on to the layer immediately below and outside them; this layer again conveys them to the next in order, and so on, till at last a little gathering stream drips from the ends of the lowest and longest outward-pointing boughs on to the soil beneath them. The ground in the centre remains perfectly 


\section{THE ROO'T OF THE MATTER.}

dry, while a circle at the circumference is hollowed into a sort of irregular trench, or rude round of tiny pits, by the continuous dripping of the collected gutters.

Now, of course, the plant wants to utilize to the utmost all the rain it thus intercepts. It would be quite too silly of it to produce rootlets and absorbent terminals in the dry central space covered by the dense umbrella of foliage. But all around the circumference, and especially at the spots just under the runnels, where the water drops from the ends of the boughs, exactly as it drops from the rib-points of the silk-and-steel umbrella, the tree develops numerous minute rootlets, which suck up the rain as fast as it falls, and convey it by fixed pipes to the leaves and growing-points. Every tree and every large herb is thus a regular and wellorganized catchment-basin, with its own mains and services; and it utilizes its watersupply by a cunningly adapted system of sucking rootlets, all placed at the exact spots 


\section{MOORLAND IDYLLS.}

where they will most surely absorb the amount of water that in each case runs down to them. So much is this true that in transplanting trees foresters and nurserymen know well you must lop the roots and the branches so as to cover equal superficial areas, or else the water will not fall on the parts best adapted to receive it; for, just as the lopped branches put forth new leaves and twigs at the point of section, so do the lopped roots put forth new rootlets and absorbent hairs at the place where they are now most urgently needed.

Not every kind of plant, however, manages its water-supply on the self-same system. There are dodges and devices. For herbs with leaves that spring from the rootstock alone, for example, without any visible aboveground stem, two main plans have been very widely adopted. One plan is that invented by plants like rhubarb, which have channelled leaves with grooved leaf-stalks, conducting all the water that falls upon their 


\section{THE ROOT OF THE MATTER.}

surface centrally towards the root. This is the centripetal type. Such plants resemble rather a funnel than an umbrella. They have always a straight tap-root, like a carrot ; and this tap-root gives off numerous short rootlets on every side, which absorb all the water as it trickles down along the tapering surface of the inverted cone. The other plan-the centrifugal type-is adopted by certain plants with heart-shaped or arrowshaped leaves, which have round leaf-stalks. In these cases the individual leaves point outward and downward, and the water drips from them not inward towards the centre, but outward towards the circumference. Their principle is rather umbrella-like than funnel-like. To meet this catchment system they have no long and descending tap-root, but just a short knobby root, which gives off long fibres radially in every direction; and these fibres terminate in knots or groups of absorbent rootlets exactly beneath the points where each leaf drips-the knobs or 


\section{MOORLAND IDYLLS.}

tags of the umbrella, to carry out our convenient metaphor. Examination of other and more complex plants reveals always the action of the same general law ; each species has a peculiar catchment system of its own, more or less complicated, by means of which, directly or indirectly, all the water that falls upon its foliage is finally conducted to certain specified spots or drinking-places; and at those specified spots the plant provides beforehand an elaborate system of absorbent organs, exactly sufficient to suck up and utilize the average amount of water it expects to obtain and store at each of them. If London were a plant, nowBut hush! I am silent. A gathering frown on the reader's brow warns me in time to steer clear of such human and political analogies. 
XXVI.

\section{THE DEVIL'S PUNCHBOWL.}

On Sunday the boys came home for their half-term holiday, so we strolled in the morning into the Devil's Punchbowl. That is the name of the basin-shaped valley that lies behind the house-a deep circular glen, scooped out in a softer portion of the sandstone mass that forms the moor by rain and denudation. Thor owned it, I doubt not, long before it was claimed by its present possessor, for the parish is Thursley; and some Celtic god, whose name is only known to Professor Rhys, may have used it as his drinking-cup long before the Norseman brought his Thor, or the Saxon his Thunor, into the Surrey uplands. But the devil is 


\section{MOORLAND IDYLLS.}

now the heir-general and residuary legatee of all heathen gods deceased, be they late or early; he has come into titular ownership of their entire property. A steep path leads zigzag down the side of the escarpment into the bowl-shaped hollow; at its bottom a tiny stream oozes out in a spring as limpid as Bandusia. Water lies in the rock, indeed, at about two hundred and fifty feet below the surface of the moor, to which depth we have, accordingly, to sink our wells on the hilltop; and it is at about the same level that the springs gush forth which form the headwaters of our local rivers.

When we came upon the brook, as good luck would have it, a couple of farm labourers, in their workaday clothes, regardless of the Sabbath, lay at full length upon the bank, engaged in the picturesque, if not strictly legal, occupation of tickling trout. The boys were, of course, delighted; they had never seen the operation performed before, and were charmed at its almost mesmeric 


\section{'THE DEVIL'S PUNCHBOWL.}

magic. At first the men, seeing gentlefolk approach, regarded us with disfavour, as their natural enemies, no doubt in league with the preserving landlord; but as soon as they discovered we were "the right sort," in full sympathy with the fine old poaching proclivities of the upland population, they returned forthwith to their tickling with a zest, and landed a couple of trout, not to mention a crayfish, before the very eyes of the delighted schoolboys.

Tickling trout is an ancient and honourable form of sport, which admits of much skill and address in the tickler. The fish lurk quietly under overhanging banks, where an undermined green sod impends the tiny stream; and the operator passes his hand gently over their sides once or twice till he has established confidence; then, taking advantage of the friendship thus formed, he suddenly closes his hand and whips the astonished victim unawares out of the water. 


\section{MOORLAND IDYLLS.}

It has been urged by anglers (who are interested parties) that such conduct contains an element of treachery; but all is fair in love and war, of which last our contest with the wild creatures of nature is but a minor variety; and I cannot see that it matters much, ethically, whether you land your trout on the bank under pretence of titillating his sense of touch, or treacherously hook him by false show of supplying him with a dainty dinner. Indeed, all the trout I have interviewed on the subject are unanimously of opinion that, if you must be caught and eaten at all, they had rather be caught by a gentle pressure of the naked hand than have their mouths and feelings cruelly lacerated by a barbed hook disguised as a mayfly. Which reminds me of the charming French apologue of the farmer who called his turkeys together in order to ask them with what sauce they would prefer to be eaten. "Please, your Excellency," said the turkeys, "we don't want to be eaten at all." "My 


\section{THE DEVIL'S PUNCHBOWL.}

friends," said the farmer, "you wander from the question."

It is curious, though, to see how this mere thread of water supports a whole isolated colony of its own, composed of many dozen kinds of fish, insects, and crustaceans, who know no more of other members of their race than the people on a small Pacific island knew of the human family before Captain Cook burst upon them from the blue, with the blessings of Christianity, rum, and extermination. These trout, for example, are a group apart; they are always small, even when adult, because there is little food for them, and the stream is little. In big rivers, where there is space to turn, and provisions are plentiful, a successful trout of the self-same species runs to five or six pounds, while the very near variety which frequents great lakes not infrequently grows to forty-five or fifty. But here, in this upland rill, an ounce or two is the limit. They live mostly in pairs, like well-conducted 


\section{MOORLAND IDYLLS.}

fish, one couple to each pool or overhung basin; yet, strange to say, if one is tickled or otherwise enticed away, the widowed survivor seems always to have found a mate before three hours are over. I know most of them personally, and love to watch their habits and manners. They are brilliantly speckled here, because the water is clear and the bottom pebbly; for the spots on trout depend on the bed, and come out brighter and more ornamental by far during the breeding season. This is still more conspicuously the case with the rsthetic stickleback, the dandy of the fresh waters; he puts on the most exquisite iridescent hues when he goes a-courting, and exhibits himself to his mate more gorgeously clad than Solomon in all his glory. Unfortunately, the colours are very fugacious, for they die away at once when he is taken out of the water; but while they last, they outshine in brilliancy the humming-bird or the butterfly. Both species are great and 


\section{THE DEVIL'S PUNCHBOWL.}

determined fighters, as always happens with brilliantly decorated birds, fishes, reptiles, and insects. None but the brave deserve the fair; and bravery and rsthetic taste seem to go together. Indeed, the courageous little trout will face and drive away a murderous pike who menaces his home, while stickleback will engage one another in such sanguinary fights for the possession of their mates that only the Kilkenny cats can be named in the same day with them.

The other inhabitants of the tiny brook are far more numerous than you would imagine. Miller's-thumbs poke their big black heads out of holes in the clay bank at every quiet corner. Crayfish hide among the weeds or dart between the sedges. Stone-loach flit down stream like rapid shadows when you lift the bigger pebbles, under which they lie skulking. As for caddis-worms and water-spiders and the larvæ of dragon-flies, they are there by the hundred; while the full-blown insects-living 


\section{MOORLAND IDYLLS.}

flashes of light, as Tennyson calls thempoise their metallic blue bodies for a second over the ragged-robins that grow in the boggy hollows, and then dart away like lightning to the willow-herb in the distance. It is a world apart, this wee world of the streamlet; it has its own joys, its own fears, its own tragedies. The big solemn cows, with their placid great eyes, come down to drink at it unheeding, and blunder over the bank, and slide their cloven hoofs to the bottom through the clay, unaware that they have crushed a dozen maimed lives, and spread terror like an earthquake over fifty small fishes. But the trout and the loaches stand with tremulous fins beating the water meanwhile ten yards below, and aghast at the cataclysm that has altered for ever their native reach. Not for fully twenty minutes do they recover heart enough to sneak up stream once more to their ruined bank, and survey with strange eyes the havoc in their homesteads. 
XXVII.

\section{THE LARK IN AUTUMN.}

MEN are out on the ridge hard by catching larks with mirrors. Catching skylarks for table! Just think of the sacrilege! Listen! As I write I can hear the dear birds carolling loud even now in the divine sunshine; singing gaily at heaven's gate, as they sang for Shakespeare; pouring their full hearts, in their joy, as they poured them forth for Shelley! And these London jailbirds, slouching figures in short jackets and round-brimmed hats, have come down from their slums to our free Surrey moors, to catch and kill them! How I hope they will fail! To the lover of nature, in spite of the proverb, a bird in the bush is 


\section{MOORLAND IDYLLS.}

worth two in the hand-or, indeed, two thousand.

At this moment, to tell you true, our meadows and pastures are just thronged with skylarks. We have always dozens of them, proclaiming their gladness every sunshiny day in rich cataracts of music. But within the last few days the dozens have turned into scores and hundreds, for it is the time of the great influx of Continental larks over sea into England. There is a difference, too, though a slight one, between our true home birds and the hungry refugees who flock here for food and warmth in winter. Our native and resident skylark is the smaller bird of the two, and more russet in colour; the migrants who join him in our winter fields are both larger and darker. Their ashy isabelline plumage, cold grey granite in hue, has less of a generous rufous tinge to relieve it than in the true-born Briton. Such minor differences, indeed, between 


\section{THE LARK IN AUTUMN.}

local races of allied type occur often in nature; they are the first beginnings out of which new kinds may in time be developed by natural selection. For instance, each important river of Britain has its own breed of salmon, to be recognized at sight -so they say-by the experienced flyfisher. Thus, again, in the matter of skylarks, our English type differs slightly in shape and hue from the Continentaljust about as much as your John Bull differs from a Frenchman, or a German. As we approach the Mediterranean, a still paler and lighter form begins to take the place of the northern bird, and has been honoured (without due reason, I should think) with a separate Latin name, as a distinct species. It stands to our own ruddy-brown English skylark in something the same relation as the Moor or the Syrian stands to the Western European. This pale form, once more, straggles through Anatolia and across Central Asia; but 


\section{MOORLAND IDYLLS.}

merges in the Himalayas, Japan, and China into a russet mountain type, which is also regarded by systematic naturalists as a distinct species. The truth is, however, when you take any large area of the world together, it is impossible to draw distinct lines anywhere between one animal or plant and another. Kind melts into kind for the most part by imperceptible stages.

Even in the dreariest months our skylark still sings to us, at rarer intervals, on bright frosty mornings. He hovers over the grass when it sparkles and scintillates with crystal filigree. His music it is that so endears him to all of us. He is busy at work now, I see, in the stubble of the corn-fields, where, a useful ally of the agricultural interest, he picks out the seeds of black bindweed and corn-poppy-not unmixed, it is true, with occasional grains of wheat or barley. But he does far more good than harm, for all that. Natives and foreigners live amicably side by side, though they do not breed 


\section{THE LARK IN AUTUMN.}

together; for the immigrants, mindful of their Baltic homes, go off again in early spring, leaving the smaller British birds to mate and nest and keep up the true blue blood of the Britannic skylark. While hard weather lasts, the families flock together in large mixed bodies, for mutual protection, I suppose, or else for love of companionship ; but at the beginning of March they separate and pair, and during this tremulous season of love and courtship their song falls from the clouds still blither and louder and more constant than ever. It showers down upon us with lavish profusion. The male birds rise emulously, singing as they go, and displaying with pride their powers of song and flight before their mates and their rivals. Often they join battle at their giddy height for some coveted mate, and fight it out in the sky; she sits demure below on the dewy grass meanwhile, watching their deeds of prowess, listening to their bursting hearts, and ready to bestow herself, like ladies at a 


\section{MOORLAND IDYLLS.}

tournament, on the lover who proves himself the stoutest and the worthiest. For we must always remember that those liquid notes which thrill our souls on glad spring mornings have been acquired by the bird, not for our human delight, but as a charm for the ears of his own love-sick partner. For her he modulates his swelling throat; for her he showers down that fountain spray of melody. Time was when birds had no such musical skill, no such art of courtship; and traces still remain to us in many lands of that more primitive period. Just as man is most advanced, most civilized, most modern in Europe, so birds are most advanced, most developed, most musical of voice in the eastern continent. And just as primitive races linger on in South Africa, Polynesia, the Andaman Islands, to give us some pregnant hint of our own early ancestry, so more antique and less evolved types of bird linger on in South America and Australia, to show us some relics of the 


\section{THE LARK IN AUTUMN.}

primitive winged fauna in the days before the sense of song was developed. South American species, belonging to the same great group of perchers as our own sweetest songsters - the nightingale, the thrush, the skylark, the linnet-are not only voiceless, but do not even possess the necessary organs for producing song. European and Asiatic birds, in other words, acquired their singing habits at a later period than the one at which their ancestors parted company for good with their South American relatives. Indeed, it is pleasant for the evolutionist to think that the whole course of the world's evolution has been in one constant stream towards beauty and sweetness - towards lovelier plumage, daintier spots and dapplings, more graceful antlers, more waving crests, diviner song, intenser colour and scent of flowers. The subtlest perfumes belong to the newest types and families of blossom; the mellowest notes belong to the newest types and families of birds; the 


\section{MOORLAND IDYLLS.}

highest beauty belongs to the newest and most spiritual races of civilized humanity. The world, thank God! grows ever more lovely, more pure, more harmonious. 


\section{XXVIII.}

\section{THE SQUIRREL'S HARVEST.}

Now is the squirrel's harvest. Beech-mast and acorns are now in season. I was sitting this morning close to the smooth grey mottled trunk of an immemorial beech at Waggoner's Wells when-pat-a-pat, pat-a noise hard by, as of hurrying and scurrying feet, attracted my attention. So loud it was, one might have almost said a troop of skirmishers from Aldershot at double-quick through the woodland, save that it came from overhead; and overhead skirmishing, from "the nations' airy navies, grappling in the central blue," is happily as yet a thing of the poet's prophetic imagination. I looked up into the tree, and there, to my 


\section{MOORLAND IDYLLS.}

surprise and delight, lo! half a dozen merry squirrels, all foraging together after the rich beech-mast, which forms the larger part of their winter's provender. Even as I watched, one of the pretty harvesters descended the trunk nimbly with his sharp small claws, and approached unawares within a few feet of the spot where I was sitting. No sooner did he see me, however, than he gave me one sharp glance from his keen black eyes, perpended for a second whether to trust me or not, and then, this way and that dividing the swift mind, came quickly at the end to the safe conclusion that men were bad lots, even when they pretend to be playing the observant philosopher. So up the smooth bark he darted, quick as thought, finding his foothold by magic, as is the wont of his race, all ignorant of Newton's troublesome theory of gravitation. Then, when he knew himself well out of reach and secure from pursuit, he turned and laughed back at me with those beady black eyes of his, in merry 


\section{THE SQUIRREL'S HARVEST.}

mood, as who should say, "Ah, great clumsy creature, you can't follow me here! Don't you wish you had a gun? Wouldn't you like to catch me?"

This quaint quality of roguishness, so sadly rare in northern animals, the squirrel possesses, with not a few other monkey-like peculiarities. Such mental traits seem, indeed, to spring direct from the wild life of the woodland. The freedom which the squirrel enjoys in his native trees-the power he possesses of evading pursuit by darting along the small twigs at the end of a bough--gives him a sense of triumph over dog or man which often results in a positive habit of nothing less than conscious mockery. The opossum and the monkeys, equally tree-haunting beasts, have acquired from similar causes the same delight in insulting and ridiculing their baffled enemies. Very monkey-like, too, is the squirrel's pretty way of holding an acorn between his two fore-paws to feed himself; while in 


\section{MOORLAND IDYLLS.}

general intelligence and sense of humour he hardly at all falls short of his southern competitor. The woods are everywhere great developers of intelligence: all the cleverest beasts and birds, including parrots and toucans, are almost without exception confirmed tree-dwellers.

I notice, too, that the squirrels are just now doubly preparing for winter; not only are they prudently stocking their larders, but they are also putting on their light suits for the season. For squirrels, even in England, still retain to some extent the ancestral habit, acquired, no doubt, during the great Ice Age, of changing their coats for a lighter one during the snowy months. In Lapland and Siberia, indeed, the local squirrels imitate the ptarmigan and the ermine by turning grey in winter; in Britain, they have lost that habit as a regular climatic change, but the fur, nevertheless, gets interspersed in places with a number of whitish hairs as the cold season approaches. It is 


\section{THE SQUIRREL'S HARVEST.}

a trick of atavism. Your squirrel sleeps away the worst months in his cosy nest, with his bushy tail wrapped like a blanket or a martial cloak around him. Thus, that pretty adjunct serves a double purpose: in summer squirrels employ it as a balance, like the rope-dancer's pole; in winter they use it as a convenient coverlet. Now and then, in February, if a warm day turns up, they wake from their doze for a short spell, and visit one of the granaries where their nuts are stored. But, like prudent beasts that they are, they never lay by their treasure in their own nests, because their too frequent going and coming while hoarding nuts might attract attention, and so betray them unawares to the too observant stoat or the inquisitive weasel. They even take the precaution to spread their investments widely, so to speak, by garnering nuts and acorns in several holes at once among the trees that surround their own family residence. 


\section{MOORLAND IDYLLS.}

When spring returns the squirrel emerges, a sadder and decidedly a thinner beast. But there are now no nuts, no seeds, no grains; so he takes, against his will, to the young bark and tender shoots of the trees around him. About the same time, too, the squirrel's fancy lightly turns to thoughts of love; the young of last year's brood begin to mate themselves. And a pretty sight the mating is, indeed. I was strolling one day through the Nower at Dorking-a lightly wooded park-when I saw by chance one of the daintiest little idylls of real life I have ever yet been lucky enough to witness. A tiny female squirrel emerged all at once from a hole in an oak-tree, hotly pursued close behind by two ardent suitors. Round and round the trunk they ran, now up, now down, all regardless of my presence; the little lady once and again pretending to let one or other of her wooers overtake her, then pausing and looking back at him with her roguish black eyes, and finally darting 


\section{THE SQUIRREL'S HARVEST.}

away with true feminine coquetry just as he thought he had caught her. $\mathrm{Ha}$, ha! the wooing o't ! I stood and watched the pretty little comedy for full twenty minutes; and all the time it was as clear as crystal for which of her two admirers that arrant little flirt had the greater inclination. Not that she ever let him see it himself too plainly; she sometimes encouraged him awhile, and sometimes his rival. She was coy, she was forward, she was bewitching, she was cold; she employed every art known to female wiles - in one word, she was a woman. I wished those who doubt the reality of selective preferences in the lower animals could have been there to see. It was a sweet little courtship. At last the tiny coquette made her choice quite plain; and then the discomfited suitor went on his way, crestfallen, while his successful rival, too overtly triumphant, and rejoicing in his luck, gazed after him and jeered at him.

I am happy to add, however, that squirrels, 


\section{MOORLAND IDYLLS.}

once mated, are models of propriety in their domestic relations. They are strictly monogamous; they pair for life ; and they constantly inhabit the same dwelling. That last is surely a pitch of respectability to which not even the blameless London clerk who "always comes home to tea" has as yet attained. $H e$ has been known to flit on quarter-days. 


\section{XXIX. \\ A DRAINED FISHPOND.}

I CALLED in at my neighbour Major Warren Pauncefote's this afternoon, and found he was just engaged in draining the fishpond by his garden. $\mathrm{He}$ is going to deepen it and to puddle the bottom, so as to make it fit for his boys to swim in. Meanwhile he has transferred all the larger carp to a stone trough in the back yard, where I saw at once there was not half enough water for them. I'm sure he didn't mean to be cruel, for he is the humanest soldier that ever spitted Fuzzy-wuzzy in the Soudan on his sword; but all the same, to any one who understands the prime needs of fish-life, the condition of those poor carp 


\section{MOORLAND IDYLLS.}

was most sad to look at. As every one knows, they breathe the oxygen dissolved in water; and as hundreds of them were confined in this Black Hole of Calcutta, the amount at their disposal was, of course, quite inadequate. Some of the poor things were dead or dying, turning on their lustreless sides in the pathetically helpless way of suffocating fish; the others kept coming up every now and then to the surface, gasping for breath, and gulping down great open-jawed mouthfuls of air, to relieve their misery. No doubt the oxygen they thus swallow enters the body-cavity, and slightly assists them in aërating the blood, though much of it, also, may pass in the ordinary way through the gills, which are the regular and normal respiratory organs. It is always interesting to me, however, to watch fish when they come up thus to drink air at the surface, as goldfish often do when thoughtlessly confined in too small a glass basin; for in this instinctive act, as modern 


\section{A DRAINED FISHPOND.}

biologists now generally allow, we have the first faint beginnings of the evolution of lungs and the habit of air-breathing. Nay, more, terrestrial life itself, as a whole, depends in the last resort upon just such first feeble gaspings and gulpings. For lungs are nothing more, anatomically speaking, than developed swim-bladders, connected by a definite passage with the external air, and provided with a more or less perfect muscular mechanism for inhaling and expelling it.

In most fish, and in all the rudest types, the swim-bladder is merely a float or balloon, which can be filled with air, and compressed or expanded, so as to make the animal rise or sink at pleasure. But many fish exist in tropical ponds and shallow swamps to whom what has happened artificially to the carp in my friend's ornamental water happens naturally every dry season; the marshy sheets in which they live evaporate altogether, and they are therefore compelled 


\section{MOORLAND IDYLLS.}

to lie dormant in the mud without food or drink for many weeks at a time. Under these peculiar circumstances, their air-bladder has gradually developed into a true lung; and, what is odder still, we possess in various countries distinct specimens at all the intermediate stages from air-bladder to lung in proportion as the ponds which they haunt become dry for longer or shorter periods. The bow-fin of the United States, for example, lives in turbid waters which do not quite dry up, but it has acquired the habit of rising to the surface every now and then, and gulping in large mouthfuls of air, which enter its swim-bladder. It does so most frequently when the water is foul, and there has been little rainfall-in other words, when there is a scarcity of oxygen. Accordingly, its air-bladderthough not yet a true lung-is spongy and cellular in structure, being adapted for aerrating the blood that passes through it. The mud-fish of Queensland, again, to take 


\section{A DRAINED FISHPOND.}

a further stage, is a six-foot-long fish which inhabits loaded streams, where its gills do not suffice it for proper respiration; it has therefore altered its swim-bladder into a rudimentary lung, more advanced than the bow-fin's, and full of air-cells, richly supplied with blood-vessels, but consisting still of a single cavity. Nevertheless, even this imperfect lung enables the mud-fish to stroll away from its native streams at night, and wander at large on dry land by means of fins which are almost legs, and which act like the sprawling limbs of certain southern lizards. In that unnatural environment it browses on green leaves, and otherwise behaves in a most unfishlike manner. Finally, to complete our rough survey, the African lepidosiren makes its home in waters which dry up completely during the hot season ; and it therefore hibernates (or rather, æstivates) for months together in a cocoon of hard mud, where it breathes at its ease by means of true lungs, completely divided 


\section{MOORLAND IDYLLS.}

into lateral halves, and approaching in structure those of an air-breathing reptile.

This interesting series of living evolutionary fossils-links that are not missingis completed for us in some ways by the frogs and toads, which recapitulate, as it were, in their own lifetime just such an ancestral developmental history. Each of them begins life as essentially a fish-that is to say, as a tadpole breathing oxygen dissolved in water, by means of gills, and possessed of no limbs for terrestrial locomotion; he ends it as essentially a fullgrown land-reptile, breathing atmospheric air by means of lungs, having discarded his now needless fin-fringed tail, and possessed of jumping legs of great muscular power. And the metamorphosis he thus undergoes answers exactly to just such a drying-up of the ponds that bore him. In early spring, when the temporary puddles are full of water, the parent frogs lay their spawn by hundreds in the ancestral element; and soon 


\section{A DRAINED FISHPOND.}

the little black tadpoles - true fish of a primitive type in all but name-swarm forth and swim in seething masses in the momentary medium. But as the sun begins to dry up the water in their dwelling-place they lose their fins and gills, pass from fish to amphibians, and shortly hop ashore, provided with four legs and a pair of lungs specially adapted for direct air-breathing. There we have a marvellous piece of evolutionary magic still going on every day before our eyes, which would sound incredible to us if a man of science reported it for the first time from Central Africa or New Guinea. The frog, in short, shows us successively in his own person the self-same stages of development which the various mud-fish preserve for us in distant regions, as types of distinct and unrelated species. 


\section{$\mathrm{XXX}$ \\ AN INTERVIEW WITH \\ A COCK-SPARROW.}

"Believe me," said the sparrow, "it pays to be civilized."

"You seem to have found it so," I answered. "You and the rook, I take it, are just the two of our birds which have lost nothing and gained much by man's presence in our island."

"I believe you," said the sparrow, cocking his head on one side. He seemed ill to recognize the solemnity of being interviewed, which to the human subject is like having your photograph taken, combined with a compound visit to the dentist. "We are a dominant race, you see; that's just where it 


\section{THE COCK-SPARROW.}

is. We have adapted ourselves to the environment. Birds like jays and hawfinches, now, are too shy and retiring: as civilization advances, they retreat and skulk and can't march with the age; but we and the rooks, we take advantage of every increase of human population to redouble our numbers. As fast as cultivation grows, we grow; man exists to provide us with food and shelter."

"Then you think your race has increased, and is still increasing?" I asked.

"Not a doubt of it, my dear sir. We have multiplied enormously. Before the age of tillage, we were probably a small and unimportant group, no more conspicuous or remarkable in any way than the wretched little siskins, or the grasshopper-warblers. But as cultivation develops, we develop, if you will excuse my Latin, pari passu. (Oh, yes, I know Latin well, because a near cousin of mine is the Passer Italia.) However, as I was going to say when you interrupted 


\section{MOORLAND IDYLLS.}

me with a question, we have spread about everywhere that grain will grow in Europe. That's because we are bold, courageous birds, not afraid of every passing object we see, like the bluethroats and the creepers; while at the same time we are cautious, quick, eager, and wary, and get out of the way of danger at a moment's notice. My own opinion is that even in Europe we must have been a mere handful of birds before cultivation spread, and that since that time we have pushed ourselves by our energy and enterprise into a leading position. About great cities alone, we may be reckoned by our myriads; and then, just look at our colonial expansion!"

"You have emigrated largely, I believe," I said, "to America and the Colonies?"

"Bless my soul, yes; we have followed European civilization almost everywhere. We allow mankind to go ahead of us for a few years, just to prepare the way, and get our corn and oats into working order; 


\section{THE COCK-SPARROW.}

and then we gain a foothold in the newly acquired lands, and naturally oust the uncivilized natives. We have annexed America, and are killing out inferior types in many other regions. What do I mean by inferior types? Why, non-sparrows, of course; such lower grades, don't you know, as Australians and New Zealanders."

"Excuse my asking a delicate question, but do you do much damage, from the farmer's point of view, to the crops and the gardens? You see, we men have a narrowminded way of regarding these things from a somewhat restricted human standpoint."

The sparrow gazed at me hard out of the corner of his eye. "Well, I don't want it put in print," he said confidentially, "for farmers are so unreasonable; but I will admit that at certain times of the year we do pick up a good many seeds out of fields and gardens. But then, consider how many insects we help to eat up. Why, I lived for a week last year upon aphides-what the 


\section{MOORLAND IDYLLS.}

farmers call bean-bugs. We must be philosophical, my dear sir; we must be philosophical. There's a give-and-take in these affairs, you may depend upon it."

He ruffled his neck as he spoke, and I observed it was marked by a conspicuous black band I had never before noticed.

"That's a pretty cravat of yours," I interposed, just to change the subject.

"Yes, it is pretty," he admitted, swelling himself out a bit as he said it. "Our women don't have them, you know, nor the young ones either. This beautiful decoration is the peculiar glory and special distinction of the adult cock-sparrow." And anything cockier than he looked at that moment it would be hard to imagine.

It occurred to me as he spoke that I had seldom seen a slenderer form of masculine adornment on which to pride one's self, till I suddenly recollected that a black moustache on a human face must be as relatively inconspicuous to any other species; and I 


\section{THE COCK-SPARROW.}

have never noticed that the possessors of well-grown black moustaches under-rated their importance.

"You have a large family, I believe," I remarked, as he chirped to his mate cheerily.

"Oh, several of them," he answered with a nonchalant air; "sometimes as many as three yearly. We are a dominant race, you know, and we don't always trouble to build our own nests; we just drive out a housemartin, or take possession of a sand-martin's burrow in a cutting. Arbitrary, did you say? Oh, well, you see, we are sparrows; and, of course, we can make a much better use of them. Poor devils of martins, they have to go elsewhere, and house themselves as best they may-the survivors, that is to say, for a good many of them get killed and torn to pieces in the process of readjustment. They're such savages, you see; we're obligea to be sharp with them. Why, I've known a horde of house-martins fight in defence of 


\section{MOORLAND IDYLLS.}

their wretched mud hovels till we were compelled to exterminate them. Well, I'm off now; ta-ta! Mind you send me a copy of your paper with this interview. And oh, by the way, if you describe my wife, just make the most you can of that pale streak over her eye, will you? It is all she has to be proud of, poor thing. She's not as distinguished-looking as I am, of course; but let her down gently, please; do let her down gently." 


\section{XXXI.}

\section{THE GREEN WOODPECKER.}

WE live so closely and familiarly with nature on the isolated hilltop, where my cottage is perched, that we often behold from our own drawing-room windows pretty rural sights, which seem intensely strange to more townbred visitors. A little while since, for example, I was amused at reading in an evening newspaper a lament by a really well-informed and observant naturalist on the difficulty of actually seeing the nightjar, or fern-owl, alight upon a tree, and stand, as is his wont, lengthwise, not transversely to the branch that bears him. Now, from our little bay lattice that doubting Thomas might see the weird bird nightly, not twenty 


\section{MOORLAND IDYLLS.}

yards off, the whole summer through, crooning its passionate song, full in view of our house, from a gnarled old fir-tree. So again this morning, at breakfast, we raised our eyes from the buttered eggs and coffee, and they fell at once on a big grcen woodpecker, creeping upward, after his fashion, along a russet-brown pine-trunk, not fifteen feet from the place at table where we were quietly sitting. One could make out with the naked eye the dark olive-green of his back, relieved by the brilliant crimson patch on his gleaming crown. For several minutes he stood there, clambering slowly up the tree, though we rose from our seats and approached quite close to the open window to examine him. When he turned his head, and listened intently after his tapping, with that characteristic air of philosophic inquiry which marks his species, the paler green of his under parts flashed for a second upon us ; and when at last, having satisfied himself there was nothing astir under the bark of 


\section{THE GREEN WOODPECKER.}

the stunted pine, he flew away to the next clump, we caught the glint of his wings and the red cap on his head in motion through the air with extraordinary distinctness.

The yaffle, as we call our red-headed friend in these parts, is one of the largest and handsomest of our woodland wild birds. About a foot in length, by the actual measurement, "from the end of his beak to the tip of his tail," he hardly impresses one at first sight with a sense of his full size, because of his extreme concinnity and neatness of plumage. A practical bird, he is built rather for use than for vain gaudy display; for, though his colour is fine, and evidently produced by many ages of æsthetic selection, he yet sedulously avoids all crests and top-knots, all bunches and bundles of decorative feathers protruding from his body, which would interfere with his solid and business-like pursuit of wood-burrowing insects. How well-built and how cunningly evolved he is, after all, for his special purpose! 


\section{MOORLAND IDYLLS.}

His feet are so divided into opposite pairs of toes-one couple pointing forward and the other backward - that he can easily climb even the smooth-barked beech-tree, by digging his sharp claws into any chance inequality in its level surface. He alights head upward, and moves on a perpendicular plane as surely and mysteriously as a lizard. Nothing seems to puzzle him ; the straightest trunk becomes as a drawing-room floor to his clinging talons. But in his climbing he is also aided not a little by his stiff and starched tail, whose feathers are so curiously rigid, like a porcupine's quills; that they enable him to hold on and support himself behind with automatic security. Long ancestral habit has made it in him "a property of easiness." A practised acrobat from the egg, he thinks nothing of such antics; and when he wishes to descend he just lets himself drop a little, like a sailor on a rope, sliding down head uppermost, and stopping himself when he wishes by means of his 


\section{THE GREEN WOODPECKER.}

claws and tail, as the sailor stops himself by tightening his bent fingers and clinging legs round the cable he is descending.

But, best of all, I love to watch him tapping after insects. How wise he looks then! how intent! how philosophic! When he suspects a grub, he hammers awhile at the bark; after which he holds his head most quaintly on one side with a quiet gravity that always reminds me of John Stuart Mill listening, all alert, to an opponent's argument, and ready to pounce upon him. If a grub stirs responsive to the tap, tap, tap of his inquiring bill-if his delicate ear detects a cavity, as a doctor detects a weak spot in a lung with his prying stethoscope-in a second our bird has drilled a hole with that powerful augur, his wedge-shaped beak, has darted out his long and extensile tongue, and has extracted the insect by means of its barbed and bristled tip. The whole of this mechanism, indeed, is one of the most beautiful examples 


\section{MOORLAND IDYLLS.}

I know of structures begotten by long functional use, and perfected by the action of natural selection. It is not only that the bill is a most admirable and efficient boring instrument; it is not only that the tongue is capable of rapid and lightning-like protrusion; but further still, the barbs at its ends are all directed backward, like the points of a harpoon, while the very same muscles which produce the instantaneous forward movement of the tongue press at the same time automatically on two large salivary glands, which pour forth in response a thick and sticky secretion, not unlike birdlime. The insect, once spotted, has thus no chance of escape; he is caught and devoured before he can say "Jack Robinson" in his own dialect.

But though the green woodpecker is so exceedingly practical and sensible a bird, built all for use and very little for show, he is not wholly devoid of those external adornments which are the result of generations of 


\section{THE GREEN WOODPECKER.}

æsthetic preference. Dominant types always show these peculiarities. His ground-tone of green, indeed, serves, no doubt, a mainly protective function, by enabling him to escape notice among the leaves of the woodland; and even on a tree-trunk he readily assimilates with the tone of the background; but his brilliant crimson cap is a genuine piece of decorative adornment, which owes its origin, no doubt, to the selective preferences of his female ancestors for endless generations. 


\section{XXXII.}

\section{THE HAREBELL.}

Few English flowers are better known than the harebell; yet I wonder what proportion of all those who love it well in its summer beauty would be able to account for its botanical name of Round-leaved Campanula. "Round-leaved!" most people would say; "why, its leaves are slender and narrow and grass-like." And so they are, indeed, in the later state in which you pick in July the graceful pensile blossoms. But the flowering stage of every plant is, after all, but its momentary reproductive period; it represents, so to speak, the golden prime of the full-grown individual. Before that stage is attained, the plant itself has to 


\section{THE HAREBELL.}

grow and prepare for flowering; it has to pass through its adolescence and its formative epoch. Now, the harebell is a herb whose two ages of life are singularly different; if you saw it in its green youth, when it is devoting itself wholly to feeding and storage, you would never imagine it was the selfsame plant as that whose tall and very slender stem supports in later life the scattered group of drooping blue bell-flowers with which you are familiar.

Here on the dry sandbank, beside the path that runs obliquely across the moor, I see half a dozen harebell-worts in the first, or caterpillar, stage of their existence. The metaphor is less violent by far than you would at first imagine, for in its earlier days the harebell, like the caterpillar, does nothing but eat and lay by for the future; while in its second or flowering stage it does nothing but put forth its tender blue blossoms, which answer to the butterfly 


\section{MOORLAND IDYLLS.}

both in their attractive beauty and in the fact that they serve to produce the seeds (which are the analogues of eggs) for the coming generation. In the purely preparatory, or hard-eating, stage, the harebell has no stem or branches to speak of; it consists of a rosette of large orb-like leaves, often heartshaped towards the stalk, and pressed close to the ground in a spreading circle. Each such rosette springs in April from a buried rootstock, which, in loose loamy soil, like that of these Surrey moors, is often intricate; it burrows in and out with strange instinct among the dry sand and stones, in search of such rare moisture as it can manage to find for itself. But though water is scarce, access to light and air is easy; so the large round leaves, lying close on the bare ground, get sunshine in abundance, and feed to their hearts' content upon their proper food-the carbon in the atmosphere -while vegetation around is still low and backward. In this stage they may be 


\section{THE HAREBELL.}

compared to the rosettes of London-pride, which are similarly clustered, but which do not die down as the flower-stem advances.

About June, however, the harebell plant has eaten and drunk enough to venture upon leaving its caterpillar stage behind, and sending up the loose cluster of waving blue flowers which represent its butterfly. In order to do this, and overtop the tall grasses which have sprouted meanwhile, it withdraws the whole of the living green-stuff from its heart-shaped root-leaves, and uses up the active material they contain in building its flower-stem. Thus, as the stem lengthens, and the buds begin to swell, the lower leaves die away altogether; only a few quite dissimilar and very narrow blades on the ascending branches now represent the original foliage. After the flowers have set, even these last disappear, or dry up on the stem, their living material being withdrawn in turn to supply food for the 
developing seeds. This may seem odd at first, but it is a common incident in many life-histories of plants and animals. As a rule, indeed, the butterfly or winged stage of most insect lives is wholly devoted to a marriage flight; and there are several winged insects which never feed at all in the perfect state; they use themselves up in the formation of eggs, and then die of inanition.

Most of the sister campanulas, like Canterbury bells, are stiff and coarse and hairy plants, without grace or elegance; but that is because they haunt woods and copses, or overgrown hedgerows, where they are sheltered from the wind, and enabled to grow large and rampant. The harebell, on the contrary - the oread of its race-is a denizen of the open, wind-swept uplands; it loves the moors and heaths, the bare hilly pastures; and it has learnt in consequence to bend lightly before the breeze, springing up again as those invisible feet pass on, 


\section{THE HAREBELL.}

which gives it its familiar slenderness and elegance. The hanging domes of the flowers are entered from below by bumble-bees, which are strong enough to push aside the fringed and close-set teeth that edge the base of the stamens, put there on purpose to baffle less useful honey-thieving visitors. Equally strange is the egg-shaped capsule which, later on, contains the seeds; it opens by five short clefts near the top. The actual reason for this arrangement is itself a somewhat odd one. The seeds can only drop out through the pores or clefts when a high wind blows and sways the waving stem violently. At such times the little grains get carried by the breeze to considerable distances; and this serves not only to disseminate the kind, but also to carry the majority of the seeds to unoccupied spots, where rotation of crops can thus be secured by letting the young plants sprout at a distance from the soil exhausted by their mother. Similar devices for securing rotation 


\section{MOORLAND IDYLLS.}

are common in nature; they often occur in species like this, whose seeds seem at first sight wholly unprovided with wings, or floats, or other means of locomotion. 


\section{XXXIII.}

\section{THE UNTAMABLE SHREW.}

$\mathrm{By}$ the hedgerow in the garden my terrier, Freckle, has just come across two pugnacious shrews, engaged in one of their sanguinary battles. The high belligerent parties are not exactly formidable to outsiders, it is true, being not quite three inches long apiece from snout to haunches, not counting an inch and a half of tail, oddly square in outline, to finish off their appearance. Yet they are savage fighters, for all that, in their intertribal quarrels. When shrew meets shrew, then comes the tug of war. It very seldom happens that they do not join battle, and the victor in the fray usually kills and eats his discomfited rival. 


\section{MOORLAND IDYLLS.}

So fierce a heart in so small a body is rare, but the shrew knows not what fear means. This particular pair of combatants were so automatically intent on the fortunes of war that Freckle was upon them and investigating their nature with her inquisitive nose before they even woke up to the fact of her presence.

Most people seem to confuse shrews with mice; but, indeed, our small combatants are widely different creatures from those timid little beasts; they belong to a wholly different group of mammals. Mice are rodents, descendants of the same common ancestor with the rats and dormice, and not remotely related to the squirrels and the rabbits. Shrews, on the other hand, are insectivores, first cousins of the moles, the hedgehogs, and the desmans. Externally, it is true, they resemble considerably the mice and voles; but those who have followed the course of recent natural history must be aware 


\section{THE UNTAMABLE SHREW.}

by this time that "appearances are deceitful." If an animal looks very much like something else, the chances are that it is altogether different. This is particularly the case with the insectivores and the marsupials, each of which great groups has independently developed a series of forms absurdly like the mice, the squirrels, the porcupines, and the jerboas, because each fills approximately the same place in nature. For example, small mammals which creep about among grass and matted herbage are likely to assume a mouse-like shape. This has happened among rodents in the case of the mice and field-voles, among invectivores in the case of the shrews, and among Australian marsupials in the case of the pouched kangaroo-mice. Our English shrew is a pretty little creature of this common type, with thick soft fur like a mouse's, only a trifle redder, and so mousey in shape that it is seldom discriminated from the true mice, save by naturalists and 


\section{MOORLAND IDYLLS.}

gamekeepers. Even externally, however, it differs much from mice in its long pointed snout-a marked insectivorous featureas well as in its square and abruptly cut-off tail, where the mouse's is rounded, tapering, and slender. When you come to the teeth and internal anatomy, however, the creature is an insectivore, displaying at once quite a separate character.

Mice, as everybody knows, feed mainly on seeds and grains, though they are fairly omnivorous, and do not despise either bees or beetles. But the shrew, less promiscuous, eschews all vegetable foods; he makes his diet entirely of insects, worms, and slugs, of which he devours an incredible number. Hence he haunts for the most part dry fields and gardens, where such prey is abundant. His preference is also for a soft sandy or light loamy soil, in which he can burrow with ease with the muzzle alone, for his slender feet are ill adapted for digging through hard earth or clay. A 


\section{THE UNTAMABLE SHREW.}

relative of the mole, he makes long runs, like his cousin, through the soft surface-soil in search of insects; but, unlike the mole again, he has preserved his small, keen eyes intact, and lives, on the whole, as much above ground as beneath it. Yet his cousinship stands him in small stead with his big purblind relation; for moles catch and eat shrews in considerable numbers. This is not to be wondered at, perhaps, when one reflects that the unnatural shrews also eat one another. Cannibalism, indeed, is an unamiable trait common to man and the insectivores. Weasels, owls, and cats are also great shrew-killers ; though, strange to say, the shrew, when killed, is by no means always eaten. I put this down in the main to the powerful scent-glands, which run along the side of the body, or occur at the root of the tail, in most species of shrew, and which secrete a very strong and odorous liquid. This liquid, I fancy, is partly protective, partly attractive to the 


\section{MOORLAND IDYLLS.}

opposite sex. It would seem to be distasteful to outsiders, but not unpleasant to insectivores themselves, for cats will kill a shrew from pure love of sport, or by mistake for a mouse, but will seldom or never eat it, whereas shrews themselves and moles have no such prejudice. Owls, also, eat shrews, in spite of their flavour. I believe such sexually attractive scents almost always coexist with the pugnacious temperament. All musky-perfumed animals fight savagely with one another for possession of their females, as do also those with marked frills or top-knots.

Shrews, though comparatively seldom seen by incurious eyes, abound by myriads in most parts of England. Every summer they increase sevenfold; but as autumn approaches, and food grows scarce, they die off in their thousands from cold and hunger, as I gather. So many of them then strew the footpaths in sandy districts that country people have a quaint superstition about 


\section{THE UNTAMABLE SHREW.}

them; they say a shrew cannot cross a church-path without dying instantly. What constitutes a church-path is somebody having once gone to church along it. The truth is, dead shrews abound equally in the grass and thickets; but, of course, only those are seen which happen to die in the open. This is but one out of many hundred odd superstitions about the shrew, which may be regarded, indeed, as the most wizard-like animal now left in England.

THE END. 
PRINTED BY WILLIAM CLONES AND SONS, LIMITED, 


\section{GOOD NOVELS BY GOOD AUTHORS,}

(Chatro \& Windus's Catalogue of over 600 Novels will be sent free by post.)

\section{POPULAR SIXPENNY EDITIONS}

(Uniform Style); or, in Cloth, Is. The Golden Butterfly. By The Woman in White. By Wilkir Collins.

The Moonstone. By Wilkie Collins.
The Cloister and the HEARTH. By CharLES READz.

It is Never Too Late to MEND. By CHARLES Rzadz.

Christie Johnstone \& Peg WOFFINGTON. BY CHARLES READI.

奖

SIR WALTER BESANT \& JAMES RICE'S NOVELS.

Crown 8vo, cloth extra, 35. 6d. each ; post 8vo, illustrated boards, 2s. each ; cloth, 2s. 6d. each.

Ready-Money Mortiboy. My Little Girl.

With Harp and Crown. This Son of Vulcan. The Golden Butterfly. The Monks of Thelema.
By Celia's Arbour. The Chaplain of the Fleet. The Seamy Side. The Case of Mr. Lucraft. 'Twas in Trafalgar's Bay. The Ten Years' Tenant.

* Also a Library Edition of the above Twelve Novels, set in new type on a large crown $8 \mathrm{vo}$ page, and bound in cloth extra, 6s. each.

LONDON : CHATTO \& WINDUS, PICCADILLY 


\section{SIR WALTER BESANT'S NOVELS.}

Crown 8 vo, cloth extra, 3s. $6 \mathrm{~d}$. each; post 8 vo, illustrated boards, 2s. each; cloth, 2s. $6 \mathrm{~d}$. each.

All Sorts and Conditions of Men.

The Captains' Room.

All in a Garden Fair.

Dorothy Forster.

Uncle Jack.

Children of Gibeon.

The World Went Very

Well Then.

Herr Paulus.

For Faith and Freedom.
To Call Her Mine.

The Bell of St. Paul's.

The Holy Rose.

Armorel of Lyonesse.

St. Katherine's by the Tower.

Verbena Camellia Steph. anotis.

The Ivory Gate.

The Rebel Queen.

Crown 8vo, cloth extra, 6s. each.

Beyond the Dreams of Avarice. In Deacon's Orders. $r^{2}$

\section{CHARLES READE'S NOVELS.}

Crown 8vo, cloth extra, illustrated, 3s. 6d. each; post 8vo, boards, 2s. each.

Peg Woffington.

Christie Johnstone.

It is Never Too Late to Mend.

The Course of True Love

Never Did Run Smooth. The Autobiography of a Thief.

Love $\mathrm{Me}$ Little, Love $\mathrm{Me}$ Iong.

The Double Marriage. The Cloister and the Hearth.

Hard Cash.
Griffth Gaunt. Foul Play.

Put Yourself in His Place.

A Terrible Temptation.

A Simpleton.

The Wandering Heir.

A Woman-Hater.

Singleheart and Doubleface.

Good Stories of Men and Other Animals.

The Jilt.

A Perilous Secret.

Readiana.

LONDON : CHATTO \& WINDUS, PICCADILLY. 


\section{WILKIE COLLINS'S NOVELS.}

Crown 8 vo, cloth extra, 3s. 6d. each ; post 8 vo, illustrated boards, 2s. each ; cloth, 2s. 6d. each.

Antonina.

Basil.

Hide and Seek.

After Dark.

The Two Destinies.

The Dead Secret.

Queen of Hearts.

The Woman in White.

No Name.

My Miscellanies.

Armadale.

The Moonstone.

Man and Wife.

Poor Miss Finch.

Miss or Mrs.?
The New Magdalen.

The Frozen Deep.

The Law and the Lady.

The Haunted Hotel.

The Fallen Leaves.

Jezebel's Daughter.

The Black Robe.

Blind Iove.

Heart and Science.

"I Say No."

A Rogue's Life.

The Evil Genius.

Little Novels.

The Legacy of Cain.

\section{羿 \\ GRANT ALLEN'S NOVELS.}

Crown $8 \mathrm{vo}$, cloth extra, 3s. 6 d. each ; post $8 \mathrm{vo}$, illustrated boards, 2s. each.

Philistia.

Babylon.

Strange Stories.

The Beckoning Hand.

For Maimie's Sake.

In all Shades.

The Devil's Die.

This Mortal Coil.

The Tents of Shem.

The Great Taboo.
Dumaresq's Daughter.

The Duchess of Powysland.

Blood Royal.

Ivan Greet's Masterpiece.

The Scallywag.

Dr. Palliser's Patient.

Fcap. 8vo, cloth, Is. 6 d.

LONDON: CHATTO \& WINDUS, PICCADILLY. 


\section{JAMES PAYN'S NOVELS.}

Crown $8 v o$, cloth extra, 3s. $6 \mathrm{~d}$. each ; post 8 vo, illustrated boards, 2s. each.

Lost Sir Massingberd. Walter's Word.

Less Black than We're Painted.

By Proxy.

For Cash Only.

High Spirits.

Under One Roof.

A Confidential Agent.

A Grape from a Thorn.
From Exile. Holiday Tasks.

The Canon's Ward. The Talk of the Town. Glow-Worm Tales. The Mystery of Mirbridge. The Word and the Will. The Burnt Million. Sunny Stories.

A Trying Patient.

Post 8vo, illustrated boards, 2s. each.

Humorous Stories. The Foster Brothers. The Family Scapegrace. Married Beneath Him. Bentinck's Tutor.

A Perfect Treasure.

A County Family. Like Father, Like Son.

A Woman's Vengeance. Carlyon's Year. Cecil's Trust. Murphy's Master. At Her Mercy. The Clyffards of Clyffe.
Found Dead. Gwendoline's Harvest. A Marine Residence. Mirk Abbey. Some Private Views. Not Wooed, But Won. Two Hundred Pounds Reward.

The Best of Husbands. Halves.

Fallen Fortunes.

What He Cost Her. Kit: a Memory.

A Prince of the BJood. 


\section{CLARK RUSSELL'S NOVELS, \&C.}

Crown 8vo, cloth extra, 6s. each; post 8vo, illustrated boards, 2s. each ; cloth limp, 2s. 6d. each.

Round the Galley Fire. In the Middle Watch. A Voyage to the Cape. A Book for the Hammock.
The Mystery of the "Ocean Star."

The Romance of Jenny Harlowe.

Crown 8ro, cloth, 35. 6d. each; post 8vo, illustrated boards, 2s. each ; cloth, 2s, 6d. each.

An Ocean Tragedy.

I My Shipmate Louise.

Alone on a Wide Wide Sea.

On the Fo'k'sle Head. Post 8vo, illustrated boards, 2s. ; cloth limp, 2s. 6d.

The Phantom Death, \&c. Crown 8vo, cloth, 35. 6d.

Is He the Man? Crown 8vo, cloth, 35. 6 d.

\section{¥?}

\section{GEORGE R. SIMS'S NOVELS.}

Post 8vo, illustrated boards, 2s. each ; cloth limp, 2s. 6d. each.

Rogues and Vagabonds. The Ring o' Bells.

Tales of To-Day.

Tinkletop's Crime.

Zeph: A Circus Story, \&c. Mary Jane's Memoirs.
Mary Jane Married.

Dramas of Life.

My Two Wives.

Memoirs of a Landlady.

Scenes from the Show.

Crown 8vo, picture cover, Is. each ; cloth limp, Is. 6d. each. The Dagonet Reciter and Reader: Being Readings and Recitations in Prose and Verse selected from bis own Works by GEORGE R. SIMS.

Dagonet Ditties. (From the "Referee.")

How the Poor Live; and Horrible London.

The Case of George Candlemas.

Dagonet Abroad. Crown 8vo, cloth, 3s. 6d.

LONDON : CHATTO \& WINDUS, PICCADILLY, 


\section{MARK TWAIN'S STORIES, \&C.}

Crown 8vo, cloth extra, 7s. 6d. each.

The Choice Works of Mark Twain. Revised and Corrected throughout by the Author. With Life, Portrait, and numerous Illustrations.

Roughing It, and The Innocents at Home.' With 200 Illustrations by F. A. FrASER.

Mark Twain's Library of Humour. With numerous Lllustrations.

Crown 8vo, cloth extra, 7s. 6d. each; post 8vo (without Illustrations), illustrated boards, 2s. each.

The Innocents Abroad; or, The New Pilgrim's Progress (MARK TWAIN'S PLEasURe TRIP).

The Gilded Age. By Mark Twain and Charles Dudley WARNER. With 2 I2 Illustrations by $\mathrm{T}$. COPPIN.

The Adventures of Tom Sawyer. With III Illustrations. The Prince and the Pauper. With nearly 200 Illustrations.

A Tramp Abroad. With $3{ }_{4}$ Illustrations.

Life on the Mississippi. With 300 Illustrations.

The Adventures of Huckleberry Finn. With I74 Illustrations by E. W. KEMBLE.

A Yankee at the Court of King Arthur. With 220 Illustrations by DAN BEARD.

Crown 8vo, cloth extra, 35. 6d. each.

The American Claimant. With numerous Illustrations by HAL HURST and DAN BEARD.

Tom Sawyer Abroad. With numerous Illustrations.

Pudd'nhead Wilson. With Portrait and 6 Illustrations by LOUIS LOEB.

The £1,000,000 Bank-Note. Crown 8vo, cloth extra, 35. 6d. ; post 8vo, illustrated boards, $2 \mathrm{~s}$.

Post 8vo, illustrated boards, 2s. each.

Mark Twain's Sketches.

The Stolen White Elephant.

LONDON : CHATTO \& WINDUS, PICCADILLY. 


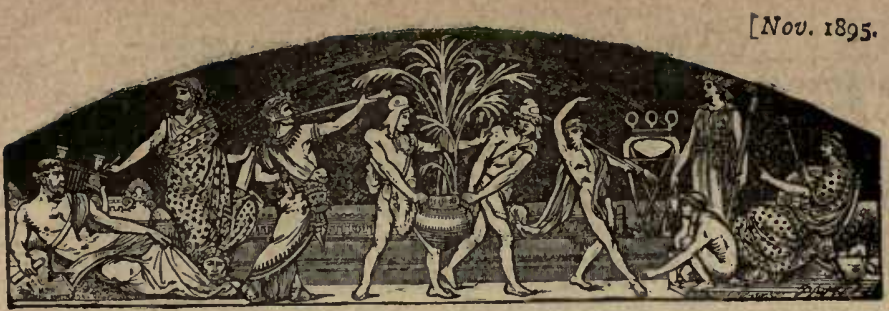

LIST OF BOOKS PUBLISHED BY

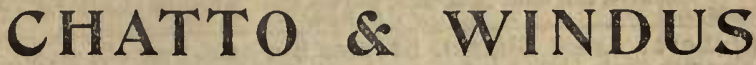

214 PICCADILLY, LONDON, W.

About (Edmond). - The Fellah: An Egyptian Novel. Translated by Sir RANDAL ROBERTS. Post 8vo, illustrated boards, 25.

Adams (W. Davenport), Works by.

A Dictionary of the Drama: being a comprehensive Guide to the Plays, Playwrights, Players, and Playhouses of the United Kingdom and America, from the Larliest Times to the Present Day. Crown 8vo, half-bound, I2s. 6 d.

Quips and Quiddities. Selected by W. DAvENPORT ADAMS. Post 8 vo, cloth imp, 2s. $6 t$.

Agony Column (The) of 'The Times,' from I80o to I870. Edited, with an Introduction, by ALICE CLAY. Post 8vo, cloth limp, 2s. 6 .

Aldé (Hamilton), Noveis by. Post 8 vo, illustrated boards, 2s. each. Carr of Carriyon.

Albert (Mary).-Brooke Finchley's Daughter. Post 8vo, picture boards, 2s, ; cloth limp, 25. $6 d$.

$\overline{\text { Alden (W. L.).-A Lost Soul : Being the Confession and Defence of }}$ Charles Lindsay. Fcap. 8 vo, cloth boards, Is. $6 d$.

Alexander (Mrs.), Novels by. Post 8vo, illustrated boards, 2s, each. Maid, Wife, or Widow?

Allen (F. M.).-Green as Grass. With a Frontispiece. Crown 8vo, cloth, 3 s. $6 d$.

Allen (Grant), Works by.

The Evolutiontst at Large. Crown $8 v o$, cloth extra, 6 s.

Post-Prandial Philosophy. Crown 8vo, art linen, $35,6 . t$.

Moorland Idylls. With numerous Illustrations. Lange crown 8 vo, cloth, 6.

[Stort'y.

Crown 8vo, cloth extra, 3s. 6d, each; post 8vo, illustrated boards, $2 s$. each.

Philistia. 12 Illustrations.

Strange Stories. Frontis.
The Beckoning Hand.

For Maimlo's Sake.

At Market $\mathbf{Y a l u e .}$

Dr. Paillser's Patient. Fcap. 8vo, cloth boards, $15.6 d$.

Crown 8vo, clotli extra, 35. 6d, each.
Dumaresq's Daughter.

The Duchess of Powysland Blood Royal.

Iyan Greet's Masterpleco.

The Scallyxas, $2+11$ lusts.

| Under Sealed Orders.

[Shortly.

Anderson (Mary).-Othello's Occupation: A Novel. Crown 8vo, cloth, $3^{s,} 6 d$.

Arnold (Edwin Lester), Stories by.

The Wonderful Adventures of Phra the Phonician. Crown 8vo, cloth extra, with rs Illustrations by H. M. PAGET, 3s. 6d. : post 8vo, illustrated boards, 25 .

The Constable of St. Nicholas. With Frontispiece by S. L. WOOD. Crown $8 v 0$, cloth, 35. $6 \pi$.

Artemus Ward's Works. With Portrait and Facsimile. Crown 8vo, cloth extra, 75. 6it.-Also a POPULAR EDITION, post 8vo, picture boards, 25.

The Genial Showman: The Life and Adventures of ARTEMUS WARD. By EDWARD P. HiNGston, With a lirontispiece. Crown 8vo, cloth extra, 35,64 . 
Ashton (John), Works by. Crown 8vo, cloth extra, 7s. 6d. each. History of the Chap-Books of the 18th Century. With 334 Illustrations. Social Life in the Reign of Queen Anne. With 85 Illustrations.

Humour. Wit, and Satire of the Seyenteenth Contury. With 82 Illustrations. English Caricature and Satire on Napoleon the First. With rys lllustrations. Modern Street Baliads. With 57 Illustrations.

Bacteria, Yeast Fungi, and Allied Species, A Synopsis of. By W. B. GROVE, B.A. With 87 Illustrations. Crown 8 vo, cloth extra, $3 s .6 n$.

Bardsley (Rev. C. Wareing, M.A.), Works by.

English Surnames: Their Sources and Significations. Crown 8 vo, cloth, 75,62 Curioslties of Puritan Nomenclature. Crown 8vo, cloth extra, 6 s.

Baring Gould (Sabine, Author of 'John Herring,' \&c.), Novels by. Red spider. Crown 8 vo, cloth extra, 35.6 . each ; post $8 v 0$, illustrated boards, 2s. each.

Barr (Robert: Luke Sharp), Stories by. Cr. 8vo, cl., 3s. 6d. each. In a Steamer Chalx. With Frontispiece and Vignette by DEMAIN HAMMOND. From Whose Bourne, \&c, With 47 Illustrations by HAL HURST and others.

A Woman Interyenes. With 8 Illustrations by HAL HURST.

Revenge! With numerous lllustrations.

[Shortly. [Shortly:

Barrett (Frank), Novels by.

Fettered for Life.

The Sin of Olga Zassoullch.

Between Life and Death.

Folly Morrison. | Honest Daxie.

Little Lady Linton.

The Woman of the Iron Braceletis.
A Prodigal's Progress.

John Ford; and Fils Helpmate.

A Recollin Yengeance.

Leut. Barnabas.| Found Gullty. For Love and Honour.

Crown 8vo, cloth, 3s. 6d.

Barrett (Joan).-Monte Carlo Stories. Fcap. 8vo, cl., is.6d.[Shortly, Beaconsfield, Lord. By T. P. O'ConNor, M.P. Cr. 8vo, cloth, 5 s.

Beauchamp (Shelsley).-Grantley Grange. Post $8 \mathrm{vo}$, boards, 2s.

Beautiful Pictures by British Artists: A Gathering of Favourites from the Picture Galleries, engraved on Steel. Imperial 4to, cloth extra, gilt edges, 2 rs.

Besant (Sir Walter) and James Rice, Novels by.

Crown $8 v 0$, cloth extra, $35.6 d$. each; post 8vo, illustrated boards, $2 s$, each ; cloth limp, 2s. 6d, each. Ready-Money Mortiboy.

My Little Girl.

With Harp and Crown,

This Son of Yulcan.

The Golden Butterfiy.

The Monks of Thelema.

By Cella's Arbour.

The Chaplain of the Eleot.

The Seamy side.

The Case of $M r$. Lucraft, \&c.

'Twas in Trafalgar's Bay, \&c.

The Ten Years' Tenant, \&c

* * There is also a LIBR ARY EDITION ol the above Twelve Volumes, handsomely set in new type on large crown 8vo page, and bound in cloth extra, 6s. cach; and a POPULAR EDITION of The Golden Butterfly, medium 8vo, 6d.; cloth, is.-NEw EDITIONS, printed in large type on crown 8vo laid paper, bound in figured cloth, $35.6 \%$. each, are also in course of publication.

Besant (Sir Walter), Novels by.

Crown 8 vo, cioth extra, 35.6 . each; post 8 vo, illustrated boards, 25 , each; cloth ilmp, 25.62 . each.

All Sorts and Conditions of Men. With r2 Illustrations by FRED, BARNARD

The Captains' Room, \&x. With Frontispiece by E. J. WHEELER.

All in a Garden Fajr. With 6 llustrations by HARRY FURNISS.

Dorothy Forster. With Frontispicce by CHARLBS GREEN.

Unole Jack, and other Storier.

The World Went Yery Well Then. With in lllustrations by A. FORESTIER.

Herr Paulus: H is Rise, lis Greatness, and his Fall. | The Bell of St. Paul'w.

For Faith and Freedom. With lliustrations by A. FORRSTIER and F. WADDY.

To Call Her Mine, \&c. With 9 lllustrations by A. FORESTIER.

The Holy Rose, \&c. Witls Frontispiece by F. BARNARD.

A rmorel of Lyonesse: A Romance of To-day. With yz Illustrations by F. BARNARD,

St. Katherine's by the Tower. With 12 llustrations by C. GREEN,

Yerbena Camellia Stephanotis, \&c. With a Frontispiece by GORDON BROWNB.

The Iyory Gate.

The Rebel Queen.

Beyond the Dreams of Avarice. Crown $8 v 0$, cloth extra, $6 s$.

In Deacon's Orders, \&c. With Frontispiece by A. FORESTIER. Crown 8vo, cloth, 6s.

The Master Craftsman. 2 vols., crown 8vo, 10s, net.

[Shortly.

Fifty Years Ago. With I44 Plates and Woodcuts. Crown 8vo, cloth extra, 5.

The Eulogy of Richard Jefferies. With Portrait. Crown 8vo, clotli extra, 6 s.

London. With $x 25$ lllustrations. Demy $8 \mathrm{vo}$, cloth extra, $7,6 d$.

Westminster. 'With Etched Frontispiece by F. S. WALKER, R.P.E., and I30 Illustrations by WILLIAM PATTEN and others. Demy $8 \mathrm{vo}$, cloth, $18 \mathrm{~s}$.

Sin RJchard Whittington. With Frontispicce. Crown $8 \mathrm{vo}$, art linen, $35,6 d$.

Gaspard de Collgny. With a Portrait. Crown 8vo, art linen, 3s. 6\%.

As ve Are: Is we May Be: Social Essays. Crown 8vo, linen, ós. 
Bechstein (Ludwig).-As Pretty as Seven, and other German Stories. With Additional Tales by the Brothers GRIMM, and 98 Illustrations by RICHTER. Square $8 \mathrm{vo}$, cloth extra, $6 s .6 d_{l}$; ; gilt edges, $7 s_{\text {. }} 6 d_{\text {. }}$.

Beerbohm (Julius).-Wanderings in Patagonia; or, Life among the Ostrich-Hunters. With Illustrations. Crown;8vo, cloth extra, 3s. 6 . .

Bellew (Frank).-The Art of Amusing: A Collection of Graceful Arts, Games, Tricks, Puzzles, and Charades. With 300 IMustrations. Crown 8vo, cloth extra, 4s.6d.

Bennett (W. C., LL.D.).-Songs for Sailors. Post 8vo, cl. limp, $2 s$.

Bewick (Thomas) and his Pupils. By Ausrin DoBson. With 95 1llustrations. Square 8vo, cloth extra, 6s.

Bierce (Ambrose).-In the Midst of Life: Tales of Soldiers and Civilians. Crown $8 v 0$, cloth extra, $6 s$. ; post $8 \mathrm{vo}$, illustrated boards, $2 s$.

Bill Nye's History of the United States. With I46 Illustrations by F. OPPER. Crown 8vo, cloth extra, 3s. $6 d$.

Biré "(Edmond). - Diary of a Citizen of Paris during "The Terror.' Translated by JOHN DE VILLIERS. Two Vols., demy 8vo, cloth extra, zis. [Shortly.

Blackburn's (Henry) Art Handbooks.

Academy Notes, 1875, 1877-86, 1889 , $1890,1892-1895$, Illustrated, each is.

Academy Notes, 1875-79. Complete in One Vol., with 600 llilustrations. Cloth, $6 s$.

Academy Notes, 1880-84, Complete in One Vol., with 700 Illustrations. Cloth, $6 s$.

Academy Notes, 1890-94. Complete in One Vol., with 800 Illustrations. Cloth, $7 s .6 d$.

Grosxenor Notes, 1877. $6 d$.

Grosyenor Notes, separate years from 1878-1890, each $\mathrm{I} s$.

Grosyen or Notes, Vol, I., 1877-82, With 300 lllustrations, Demy 8 vo, cloth, $6 s$.
Grosyenor Notes, Vol. II., 1883-87. WIth 300 Illustrations, Demy 8 vo, cloth, 6 s.

Grosyenor Notes, Vol. IIl., 1888-90. With 230 Illustrations. Demy 8vo cloth, 35. 6d.

The New Gallery, 1888-1895: With nu. merous Illustrations, each is.

The New Gallery, Vol. I., 1888-1892. With 250 lllustrations. Demy $8 \mathrm{vo}$, cloth, 6 s.

English Plctures at the National Gallery. With 114 lllustrations. Is.

Old Masters at the Natlonal Gallery. With 128 Illustrations. Is, $6 d$.

Illustrated Catalogue to the National Gallery. With 242 lllusts. Demy 8vo, cloth, 35 .

The Parls Salon, 1895. With 300 Facsimile Sketches. 35.

Blind (Mathilde), Poems by.

The Ascent of Man. Crown $8 \mathrm{vo}$, clotli, 55 .

Dramas in Minlature. Witl a Frontispiece by F. MADOX BROWN. Crown 8vo, cloth, 55.

Songs and Sonnets. Fcap. 8vo, vellum and gold, 5 .

BIrds of Passage : Songs of the Orient and Occident. Second Edition. Crown 8vo, linen, $6 s$, net.

Bourget (Paul).-Lies. Translated by John DE VILLIERs. Crown $8 \mathrm{vo}$, cloth, 6 s.

Bourne (H. R. Fox), Books by.

English Merchants: Memoirs in Illustration of the Progress of Brltish Commerce. With numerous Illustrations. Crown 8vo, cloth extra, 75.6d.

English Newspapers : Chapters in the History of Journalism. Two Vols., demy 8vo, cloth, $25 s$.

The Other Side of the Emin Pasha Rellef Expedition. Crown 8vo, cloth, 6 s.

Bowers (George).-Leaves from a Hunting Journal. Coloured Plates. Oblong folio, half-bound, ars.

Boyle (Frederick), Works by. Post 8vo, illustrated bds., 2s, each. Chronicles of No-Man's Land. I Camp Notes. I Savage Life.

Brand (John).-Observations on Popular Antiquities ; chiefly illustrating the Origin of our Vulgar Customs, Ceremonies, and Superstitions. With the Additions of Sir HENRY ELLIS, and numerous Illustrations. Crown 8vo, cloth extra, $7 s .6 d$.

Brewer (Rev. Dr.), Works by. The Reader's Handbook of Alluslons, References, Plots, and Storles. Seventeenth

Authors and their. Yorks, with the Dates : Being the Appendices to 'The Reader's Hand. book,' separately printed. Crowu 8vo, cloth limp, $2 s$.

A Dictionary of Miracles. Crown 8 vo, cloth extra, $75.6 d$.

Brewster (Sir David), Works by. Post 8vo, cloth, 4s. 6d. each. More Yorlds than One: Creed of the Philosopher and Hope of the Christian. With Plates. The Martyrs of Sclence: GALILEO, TYCHO BRAHE, and KEPLER. With Portraits. Letters on Natural Magic. With numerous lllustrations.

Brillat-Savarin.-Gastronomy as a Fine Art. Translated by R. E. ANDERSON, M.A. Post 8vo, half-bound, 2s.

Brydges (Harold).-Uncle Sam at Home. With gr Illustrations. Post 8vo, itlustrated boards, 25. ; cloth limp, $25.6 \%$. 
Buchanan (Robert), Works by. Crown 8vo, cloth extra, 6s. each. Solected Poems of Robert Buchanan. With Frontispiece by T. DALzIEL.

The Earthquake; or, Six Days and a Sabbatl.

The Clty of Dream : An Epic Poem. With Two Illustrations by P. MACNAB.

The Wanderlng Jew: A Christmas Carol.

The Outcast: A Rhyme for the Time. With 15 llinstrations by RUDOLF BIIND, PETER MACNAB, and HUME NISBET. Small demy 8 vo, eloth extra, $8 s$.

Robert Buchanan's Poetical Works. With Steel-plate Portrait. Crown 8vo, cloth extra, $7 s, 6 d$ Crown $8 v o$, cloth extra, 35. $6 d$. each; post $8 \mathrm{vo}$, illustrated boards, 25 , each.

The Shadow of the Sword.

A Child of Nature. Witl Frontispiece.

God and the Man. With xr lllustrations by FRED. BARNARD.

The Martyrdom of Madeline, With Frontispiece by A. W. COOPER.

Love Me for Exer. With Frontispiece.

Annan Water. i Foxilove Manor.

The Ney Abelard.

Matt: A Story of a Carayan. With Frontispiece.

The Master of the Mine. With Frontispiece. The Heir of Linne.

Crown 8vo, clotli extra, 35. 6d. each.

Yoman and the Man. I Red and White Heather.

I Rachel Done.

Lady Kilpatrick. Crown $8 v 0$, cloth extra, 6.

The Charlatan. By ROBERT BUCHANAN and HENRY MURRAY. With a Frontisplece by T. II. ROBINSON. Crown $8 v^{\circ}$, cloth, 35. $6 d$.

[Shortly.

Burton (Richard F.).-The Book of the Sword. With over 400 lllustrations. Demy 4to, cloth extra, $32 s$.

Burton (Robert).-The Anatomy of Melancholy. With Translations of the Quotations. Demy $8 v 0$, cloth extra, $7 s .6 d$.

Melancholy Anatomised : An Abridgment of BURTON'S ANATOMY. Post 8vo, half-bd., 2s. 6d.

Caine (T. Hall), Novels by. Crown 8 vo, cloth extra, 3 s. $6 d$. each. ; post $8 v 0$, illustrated boards, 2s. each; cloth limp, 2s. 6 d. each.

The Shadow of a Crime. I A Son of Hagar. I The Deemster.

A LIBRARY EDITION of The Deemster is now ready; and one of The Shadoy of a Crime is in preparation, set in new type, crown $8 v 0$, cloth decorated, 6 , each.

Cameron (Commander V. Lovett).-The Cruise of the 'Black Prince' Privateer. Post 8vo, picture boards, 2s.

Cameron (Mrs. H. Lovett), Novels by. Post 8 vo, illust. bds. 2s, ea. Jullet's Guardian. Decelyers Eyer.

Carlyle (Jane Welsh), Life of. By Mrs. Alexander Ireland. With Portrait and Facsimile Letter. Small demy 8vo, cloth extra, 7 s. $6 d$.

Carlyle (Thomas). - On the Choice of Books. Post 8vo, cl., is. $6 d$. Correspondence of Thomas Carlyle and R. W. Emerson, 1834-1872. Edited by C. E. NORTON. With Portraits. Two Vols., crown 8 vo, cloth, 245 .

\section{Carruth (Hayden).--The Adventures of Jones. With I7 Illustra-} tions. Fcap. $8 \mathrm{vo}$, cloth, 25 .

Chambers (Robert W.), Stories of Paris Life by. Long fcap. $8 \mathrm{vo}_{\text {, }}$ cloth, $25.6 \mathrm{~d}$. each. The King in Yellow.

In the Quarter.

Chapman's (George), Works. Vol. I., Plays Complete, including the Doubtful Ones.-Vol. II., Poems and Minor Translations, with Essay by A. C. SwixbURNE. -Vol. 1II. Translations of the liliad and Odyssey. Three Vols., crown 8vo, cloth, 6r, each.

Chapple (J. Mitchell). -The Minor Chord: The Story of a Prima Donna. Crown $8 \nabla 0$, eloth, $35.6 d$.

Chatto (W. A.) and J. Jackson.-A Treatise on Wood Engraving, Historical and Practical. With Chapter by H. G. BOHN, and 450 fine Illusts. Large 4 to, half-leather, 28 .

Chaucer for Children: A Golden Key. By Mrs. H. R. Haweis. With 8 Coloured Plates and 30 Woodcuts. Crown 4 to, cloth extra, $35.6 \mathrm{~d}$.

Chaucer for Schools. By Mrs. H. R. HAwE1S. Demy 8vo, cloth limp, 2s. 6d.

Chess, The Laws and Practice of. With an Analysis of the Openings. By Howard Staunton. Edited by R. B. Wormald. Crown 8vo, cloth, 5 s.

The Minor Tactics of Chess: A Treatise on the Deployment of the Forces in obedience to Stra. tegic Principle. By F. K. YOUNG and E. C. HowEL L. Long fcap. 8vo, cloth, 25. $6 \pi$.

The Flastlngs Chess Tournament Book (Aug.-Sept., r805). Containing the Official Keport of the 23I Games played in the Tournament, with Notes by the Players, and Diagrams of Interesting Positions; Portraits and Biographical Sketches of the Chess Masters; and an Account of the Congress and its surroundings. Crown $8 \mathrm{vc}$, cloth extra, 7s. 6 . net.

[Shorlly 
Clare (Austin).-For the Love of a Lass. Post 8vo, 2s. ; cl., 2s, $6 d$. Clive (Mrs. Archer), Novels by. Post 8vo, illust. boards, 2s, each. Paul Ferroll. Yhy Paul Ferroll Kllled hls wlfe.

Clodd (Edward, F.R.A.S.).-Myths and Dreams. Cr. 8vo, 3s. $6 d$. Cobban (J. Maclaren), Novels by.

The Cure of Souls. Post 8vo, Illustrated boards, 2s.

The Red Sultan. Crown 8vo, cloth extra, 3s, 6d.; post 8vo, illustrated boards, 2.5 .

The Burden of Isabel. Crown $8 v o$, cloth extra, $3 s .6 d$.

Coleman (John).-Players and Playwrights I have Known. Two Vols., demy $8 \mathrm{vo}$, cloth, 245 .

Coleridge (M. E.).-The Seven Sleepers of Ephesus. Cloth, Is. 6d. Collins (C. Allston).-The Bar Sinister. Post 8vo, boards, $2 s$.

Collins (John Churton, M.A.), Books by.

Illustrations of Tennyson. Crown $8 v o$, cloth extra, $6 s$.

Jonathan Swlft: A Biographical and Critical Study. Crown 8vo, cloth extra, 8 s.

Collins (Mortimer and Frances), Novels by.

Crown 8vo, cloth ext ra, 3s. 6d. each; post 8 vo, illustrated boards, 25 , each

From Midnlght to Midnight.

Transmigration.

You Play me False.

A Xillase Comedy.

Post 8vo, illustrated boards, 2s. each.

Sweet Anne Page. I A Fight with Fortune. | Sweet and Tyenty. I Frances.

Collins (Wilkie), Novels by.

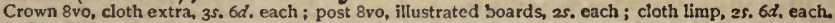

Antonina. With a Frontispiece by Sir JOHN GILBERT, R.A.

Basil. Illustrated by Sir JOIIN GIL.BERT, K.A., and J. MAHONEY.

Hide and Seek. Illustrated by Sir JOHN GILBERT, R.A., and J. MAHONEY.

After Dark. With Illustrations by A. B. HOUGHTON. | The Two Destinies.

The Dead Secret. With a Frontispiece by Sir JOHN GILEERT, R.A.

Queen of Hearts. With a Frontispiece by Sir JOHN GILBERT, R.A.

The Woman in White. With llustrations by Sir JOHN GILBERT, R.A., and F. A. FRASER.

No Name. With lllustrations by Sir J. E. MILLAIS, R.A., and A.W. COOPER,

My Miscellanies. With a Steel-plate Portrait of WILKIB COLLINS.

Armadale. With illustrations by G. H. THOMAS.

The Moonstone. With Illustrations by G. DU MAURIER and F. A. FRASER.

Man and Wife. With Jllustrations by WILLIAM SMALL.

Poor Miss Finch. Illustrated by G. DU MAURIER and EDWARD HUGHES.

Mlss or Mrs.? With Illustrations by S. L. FILDES, R.A., and IIENRY WOODS, A.R.A.

The New Magdalen. Illustrated by G. DU MAURIER and C. S. REINHARDT.

The Frozen Deep. Illustrated by G. DU MAURIER and J. MAHONEY.

The Law and the Lady. With lllustrations by S. L. FILDES, R.A., and SYDNEY HALI.

The Haunted Hotel. With Illustrations by ARTHUR HOPKINS.

The Fallen Leares. | Heart and Sclence.

Jezebel's Daughter. 'I Say No.'

The Black Robe.

The Evil Centus.

The Woman in White.

POPULAR EDITions. Medium 8vo, 6d. each; cloth, is, each.

Colman's (George) Humorous Works: 'Broad Grins,' My Nightgown and Sllppers,' $\&$ c. With Life and Frontispiece. Crown 8vo, cloth extra, $75.6 d$.

Colquhoun (M. J.).--Every Inch a Soldier. Post 8vo, boards, $2 s$. Colt-breaking, Hints on. By W. M. Hutchison. Cr. 8vo, cl., 3s. $6 \mathrm{~d}$. Convalescent Cookery. By Catherine Ryan. Cr. 8 vo, is.; cl., is. $6 d$.

Conway (Moncure D.), Works by.

Demonology and Deyll-Lore. With 65 Illustrations. Two Vols., demy 8 vo, cloth, 28 s.

George Washington's Rules of Clyllity. Fcap. 8vo, Japanese vellum, $2 s .6 d$.

Cook (Dutton), Novels by.

Paul Foster's Daughter. Crown $8 v o$, cloth extra, 3s. $6 d$.; post $8 v o$, illustrated boards, $2 s$.

Leo. Post 8vo, illustrated boards, 25 .

Cooper (Edward H.).-Geoffory Hamilton. Cr. 8vo, cloth, 3 s. $6 d$.

Cornwall.-Popular Romances of the West of England; or, The Drolls, Traditions, and Superstitions of Old Cornwall. Collected by ROBERT HUNT, F.R.S. With two Steel Plates by GEORGE CRUiKSHANK. Crown 8vo, cloth, 7s. 6d.

Cotes (V. Cecil). - Two Girls on a Barge. With 44 Illustrations by F. H. TOWNSEND, Post 8 vo, cloth, $25.6 d$. 
Craddock (C. Egbert), Stories by.

The Prophet of the Great Smoky Mountalns. Post 8vo, illustrated boards, 2s.

His Yanished Star. Crown $8 v 0$, cloth extra, 35. 6 .

Crellin (H. N.) Books by.

Romances of the Old Seragllo. With 28 llustrations by S. L. WOOD. Crown $8 v 0$, cloth, $35.6 \%$. Tales of the Callph. Crown 8 vo, cloth, 25 .

The Nazarenes: A Drama. Crown 8vo, rs.

Crim (Matt.).-Adventures of a Fair Rebel. Crown 8vo, cloth extra, with a Frontispiece by DAN. BEARD, $3 s .6 d$, ; post $8 \mathrm{vo}$, illustrated boards, $2 s$.

Crockett (S, R.) and others. - Tales of Our Coast. By S. R. CROCKETT, GILBERT PARKER, HAROLD FREDERIC, 'Q.,' and W. CLARK RUSSELL. With Iz Illustrations by FRANK BRANGWYN. Crown 8vo, cloth, 3 s. $6 d$.

[Shortly.

Croker (Mrs. B. M.), Novels by. Crown 8vo, cloth extra, $3^{\text {s. }} 6 d_{\text {. }}$ each; post 8vo, illustrated boards 25 . each ; cloth limp, 2s. 6d, each. Pretty Miss Neville. A Bird of Passage. Dlana Barrlngton. Proper Pride. Crown 8vo, cloth extra, $35.6 d$. each.

Yillage Tales and Jungle Tragedies. Mr.Jervis. Married or single? Three Vols., crown $8 \mathrm{vo}$, r5s. net.

The Real Lady Hulda.

[Shortly,

Cruikshank's Comic Almanack. Complete in Two Series: The FIRST, from 1835 to 1843 ; the SECOND, from 1844 to 1853 . A Gathering of the Best Humour of THACKERAY, HOOD, MÁYHEW, ALBERT SMITH, A'BECKETT, ROBERT BROUGH, \&c. With numerous Steel Engravings and Woodcuts by GEORGE CRU1KSHANK, HINE, LANDELLS, \&C. Two Vols., crown 8 vo, cloth gilt, $7 s, 6 d$, each.

The Llfe of George Cruikshank. By BLANCHARD JERROLD. With 84 Illustrations and a Bibliography. Crown 8vo, cloth extra, 65 .

Cumming (C. F. Gordon), Works by. Demy 8vo, cl. ex., 8s. 6d. ea In the Hebrldes. With an Autotype Frontispiece and 23 lllustrations.

In the Himalayas and on the Indian Plains. With 42 Illustrations.

Tyo Happy Xears in Ceylon. With 28 Jllustrations.

Y1a Cornwall to Egypt. With a Photogravure Frontispiece. Demy 8vo, cloth, 7s. 6d.

Cussans (John E.).-A Handbook of Heraldry; with Instructions for Tracing Pedigrees and Deciphering Ancient MSS., \&c. Fourth Edition, revised, with 408 Woodcuts and 2 Coloured Plates. Crown 8 vo, cloth extra, $6 s$.

Cyples (W.).-Hearts of Gold. Cr. 8vo, cl., 3s. 6d.; post 8vo, bds., $2 s$.

Daniel (George).-Merrie England in the Olden Time. With Illustrations by ROBERT CRUIKSHANK. Crown 8vo, cloth extra, 35.6d.

Daudet (Alphonse).-The Evangelist; or, Port Salvation. Crown 8vo, cloth extra, $35.6 d$. ; post $8 \mathrm{vo}$, illustrated boards, 25 .

Davenant (Francis, M.A.).- - Hints for Parents on the Choice of a Frofession for their Sons when Starting in Jife. Crown 8vo, rs.: cloth, rs. 6d.

Davidson (Hugli Coleman) - - Mr. Sadler's Daughters. With a Frontispiece by STANLEY WOOD. Crown $8 \mathrm{vo}$, cloth extra, $35.6 d$.

Davies (Dr. N. E. Yorke-), Works by. Cr. 8vo, Is. ea.; cl., Is. 6d. ea.

One Thousand Medical Maxims and Surgical Hints.

Foods for the Fat: A Treatise on Corpulency, and a Dietary for its Cure.

Alds to Long Lifo. Crown 8vo, 2s.; cloth limp, 2s. 6d.

Davies' (Sir John) Complete Poetical Works. Collected and Edited, with Introduction and Notes, by Rev. A. B. GROSART, D.D. Two Vols., crown 8vo, cloth, ras.

Dawson (Erasmus, M.B.).-The Fountain of Youth. Crown 8vo,

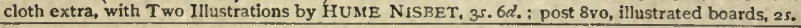

De Guerin (Maurice), The Journal of. Edited by G. S. Trebutien. With a Memoir by SAINTE-BEUVE. Translated from the 2oth French Edition by JESSIE P. FROTH. INGHAM. Fcap. 8vo, half-bound, $25.6 d$.

De Maistre (Xavier).-A Journey Round my Room. Translated by $\operatorname{Sir}$ HENRY ATTWELl. Post 8 vo, cloth limp, 2s. $6 d$.

De Mille (James).-A Castle in Spain. Crown 8vo, cloth extra, with a Frontispiece, 35.62 .; post $8 \mathrm{vo}$, illustrated boards, 25 .

Derby (The) : The Blue Ribbon of the Turf. With Brief Accounts of THE OAKS. By LOU1S HENRY CURzON. Crown 8vo, cloth limp, 25.6d. 
Derwent (Leith), Novels by. Cr. Svo, cl., 3s. 6d. ea. ; post 8vo, 2s. ea. our Lady of Tears. Clrce's Loxers.

Dewar (T. R.).-A Ramble Round the Globe. With 220 Illustra. tions. Crown 8 vo, cloth extra, $7 s .6 i_{i}$

Dickens (Charles), Novels by. Post 8vo, illustrated boards, 2s. each. Sketches by Boz. I Nicholas NIckleby. I Ollxer Twist.

About England wlth Dlckens. By AI.FRED RIMMER. With 57 lllustrations by C. A. VANDER. HOOF, ALFRED RIMMER, and others. Square 8vo, cloth extra, 7s. $6 d$.

\section{Dictionaries.}

A Dlctlonary of Mlracles : Imitative, Realistic, and Dogmatic. By the Rev. E. C. BREWER, LL.D. Crown 8vo, cloth extra, 7s. 6 .

The Reader's Handbook of Alluslons, References, Plots, and Storles. By the Rev. E. C. BREWER, LL.D. With an ENGLISH BIBLIOGRAPHY. Crown 8vo, cloth extra, $7 s .6 d$.

A uthors and thelr Works, with the Dates. Crown $8 \mathrm{vo}$, cloth limp, 25 .

Famllar Short Saylngs of Great Men. With Historical and Explanatory Notes by SAMUEL A. BENT, A.M. Crown 8vo, cloth extra, $7 s .6 . t$.

The Slang Dletlonary: Etymological, Historical, and Anecdotal. Crown 8vo, cloth, $65.6 d$.

Words, Facts, and Phrases: A Dictionary of Curious, Quaint, and Out-of-tle.Way Matters, By ELIEZER EDWARDS. Crown 8vo, cloth extra, 7s. $6 d$.

Diderot.-The Paradox of Acting. Translated, with Notes, by WALTER HERRIES POLLOCK. With Preface by Sir HENRY IRVING. Crown 8vo, parchment, 4s. $6 d$.

Dobson (Austin), Works by.

Thomas Bewick and his Pupils. With 95 Illustrations. Square 8 vo, cloth, $6 s$.

Four Frenchyomen. With Four Portraits. Crown 8vo, buckram, gilt top, 6 s.

Elghteenth Century YIgnettes. TwO SERIES. Crown 8vo, buckram, 6r, each.-A THIRD SERIES is in preparation.

Dobson (W. T.).-Poetical Ingenuities and Eccentricities. Post $8 \mathrm{vo}$, cloth limp, 2s. 6 .

Donovan (Dick), Detective Stories by.

Post 8vo, illustrated boards, 25, each; cloth limp, 2s. 6d. each.

The Man-Hunter. | Wanted.

Caught at Last.

Tracked and Taken.

Who Polsoned Hetty Duncan?

Suspiclon Aroused.

A Detectlve's Trímphs.

In the Grip of the Law.

From Information Recelyed.

LInk by Ulnk. | Dark Deeds.

The Long Arm of the Law. [Shortly.

Crown $8 \mathrm{vo}$, cloth extra, 3s. $6 \mathrm{~d}$. each ; post $8 \mathrm{vo}$, illustrated boards, $2 s$. each; cloth, $25.6 d$. each.

The Man from Manchester. With 23 Hlustrations.

Tracked to Doom. With Six full-page Illustrations by GORDON BROWNE.

The Mystery of Jamalca Terrace. Crown 8vo, cloth, $35.6 d$.

[Shortly.

Doyle (A. Conan).-The Firm of Girdlestone. Cr. 8 vo, cl., 3 s. $6 d$.

Dramatists, The Old. Crown $8 \mathrm{vo}$, cl. ex., with Portraits, $6 s$. per Vol.

Ben Jonson's Works. With Notes, Critical and Explanatory, and a Biographical Memoir by WILLIAM GIFFORD. Edited by Colonel CUNNINGHAM. Three Vols.

Chapman's Works. Three Vols. Vol. I. contains the Plays complete; Vol. 1I., Poems and Minor Translations, with an Essay by A.C. SWINBURNE : Vol. III., Translations of the Illad and Odyssey. Marlowe's Works. Edited, with Notes, by Colonel CUNNINGHAM. One Vol.

Massinger's Plays. From GIFFORD'S Text. Edited by Colonel CUNNINGHAM. One Vol.

\section{Duncan (Sara Jeannette: Mrs. Everard Cotes), Works by.}

$$
\text { Crown } 8 \text { vo, cloth extra, } 7 s . \epsilon d \text {. each. }
$$

A Social Departure. With $\mathrm{IIr}$ litustrations by F. H. TOwNSEND.

An Amerlcan Glrl in London. With 80 lllustrations by $\mathrm{F}$. H. TOWNSEND.

The SImple Adventures of a Memsahib. With 37 Illustrations by F. H. TOWNSEND.

Crown 8vo, cloth extra, 3s. 6tt. each.

A Daughter of To-Day. I Yernon's Aunt. With 47 lliustrations by HAL HURST.

Dyer (T. F. Thiselton).-The Folk-Lore of Plants. Cr. 8vo, cl., 6s.

Early English Poets. Edited, with Introductions and Annotations, by Rev. A. B. GROSART, D.D. Crown 8vo, cloth boards, 6s. per Volume.

Fletcher's (Glies) Complete Poems. One Vol.

Davles' (Slr John) Complete Poetlcal Works. Two Vols.

Herrlck'e (Robert) Complete Collected Poems. Three Vols.

SIdney's (Slr Phlilp) Complete Poetical Works. Three Vols.

Edgcumbe (Sir E. R. Pearce).-Zephyrus: A Holiday in Brazil and on the River Plate. With 4 r Illustrations. Crown $8 v 0$, cloth extra, 55 .

Edison, The Life and Inventions of Thomas A. By W. K. L. and ANTONIA DICKSON. With 200 lllustrations by R. F. OUTCALT, \&c. Demy 4to, cloth gilt, 18 s. 
Edwardes (Mrs. Annie), Novels by.
Archle Loxell.
Post 8vo, illustrated boarcls, 2s. each.

Edwards (Eliezer).-Words, Facts, and Phrases: A Dictionary of Curlous, Qualnt, and Out-of-the-Way Mattcrs. Crown 8vo, clotl), $75.6 a^{2}$.

Edwards (M. Betham $=$ ), Novels by.

K1tty. Post 8vo, boards, 2s.; cloth, 2s. 6\%. | Fellcla. Post 8vo, illustrated boards, zs.

Egerton (Rev. J. C., M.A.). - Sussex Folk and Susser Ways. With Introduction by Rev. Dr. H. WACE, and Four Illustrations. Crown 8vo, cloth estra, 5 s.

Eggleston (Edward).-Roxy: A Novel. Post 8vo, illust. boards, $2 s$.

Englishman's House, The : A Practical Guide for Selecting or Building a liouse. By C. J. RICHARDSON. Coloured Frontispicce and 534 Illusts. Cr. 8vo, cloth, 7s. 6r.

Ewald (Alex. Charles, F.S.A.), Works by.

The Lite and Times of Prince Charles Stuart, Count of Albany (THE YounG PRETRNDER). With a Portrait. Crown 8vo, cloth extra, 7s. 6 .

Storfes from the State Papers. With Autotype Frontispiece. Crown 8vo, cloth, 6 s.

Eyes, Our: How to Preserve Them. By John Browning. Cr.8vo, is.

Familiar Short Sayings of Great Men. By SAMUel ArthUR Bent, A.M. Fifth Edition, Revised and Enlarged. Crown 8vo, cloth cxtra, 7s. 62 .

Faraday (Michael), Works by. Post 8 vo, cloth extra, 4s. $6 d$. each. The Chemical History of a Candle: Lectures delivered before a Juvenile Audience. Edited by WILLIA M CROOKES, F.C.S. With numcrous Illustrations.

On the Yarlous Forces of Nature, and their Relations to each other. Edited by WILLIAM CROOKES, F.C.S. With Illustrations.

Farrer (J. Anson), Works by.

Milltary Manners and Customs. Crown 8vo, cloth extra, 6 .

War: Three Essays, reprinted from 'Military Manners and Customs.' Crown 8vo, Is. ; cloth, is. 6 .

Fenn (G. Manville), Novels by.

Crown 8vo, cloth extra, 35.6 \% each; post \&vo, unustrated boards, 2s. each,

The Ney Mistress.

I Witness to the Deed.

Crown 8vo, cloth extra, 35.6 . cach.

The Tiger Lily: A Tale of Two Passions. | The White Yirgin.

Fin-Bec.-The Cupboard Papers: Observations on the Art of Living and Dining. Post $8 v 0$, cloth limp, 2s. $6 \dot{d}$.

Fireworks, The Complete Art of Making; or, The Pyrotechnist's Treasury. By THOMAS KENTiSH. With 267 Illustrations. Crown 8 vo, cloth, 5.

First Book, My. By Walter Besant, James Payn, W. Clark Rus.

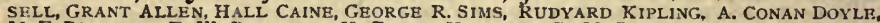
M. E. BRADDON, F. W. ROBINSON, H. RIDER HAGGARD, R. M. BALLANTYNE, 1. ZANGWILL. MORLEY ROBERTS, D. CHRISTIE MURRAY, MARY CORELli, J. K. JEROME, JOHN STRANLiB WINTER, BRET HARTE, 'Q.,' ROBERT BUCHANAN, and R. L. STEVENSON. With a Prefatory Story by JEROME K. JEROME, and 185 Illustrations. Sinall demy 8 vo, cloth extra, $7 s$. 62 .

\section{Fitzgerald (Percy), Works by.}

The World Behind the Scenes. Crown 8 ro, cloth extra, 35.62

Little Essays: Passages from the Letters of CHARLES LAMB. Post 8vo, cloth, 2s. $6 d$.

A Day's Tour: A Journey through France and Belgium. With Sketches. Crown 4 to, is.

Fatal Zero. Crown 8vo, cloth extra, 3s. $6 d$. ; post 8vo, illustrated boards, 25.

Post 8 vo, illustrated boards, $2 s$, each.

Bella Donna.

The Lady of Brantome.

The Becond Mra. Tlllotson. Polly, Nexer Forfotten. Sexenty-fixe Brooke Street.

The Llfe of James Boswell (of Auchinleck). With lllusts. Two Vols., demy 8vo, cloth, 24s.

The Saxoy Opera. With 60 lilustrations and Portraits. Crown 8vo, cloth, $35,6 d$.

Sir Henry Irxing: Twenty Years at the Lyceum. With Portrait. Crown $8 v 0$, is.; cloth, Is. $6 d$

Flammarion (Camille), Works by.

Popular Astronomy: A General Description of the Heavens. Translated by J. ELI.ARD GORE, F.R.A.S. With Three llates and 283 lllustrations. Mcdium 8 vo, cloth, 36.

Urania: A Romance. With 87 Illustrations. Crown $8 v 0$, cloth extra, $5 s$.

Fletcher's (Giles, B.D.) Complete Poems: Christ's Victorie in liezven, Christ's Victorie on Earth, Christ's Triumpl over Death, and Minor Poems. With Notes by R.av. A. B. GROSART, D.D. Crown 8vo, cloth boarcls, $6 s$.

Fonblanque (Albany).-Filthy Lucre. Post 8vo, illust. boards, 2s. 
Francillon (R. E.), Novels by.

Crewn 8ve, cloth extra, 35. 6 . eich ; post $8 v 0$, illustrated beards, 25, each.
One by One.
Ropes of $\mathbf{g a n d .}$ lllustrated.
A Real Queen.
King or Knave.
A Dog and his Shatow.

Post $8 \mathrm{vo}$, illustrated boards, 2s. each.

Queer Cophetua. | Olympla.

I Romances of the Law.

Jack Doyle'e Daughter. Crown $8 v o$, cloth, $35,6 d$.

Esther's Gloye. Ficap. 8ve, picture cever, $x$ s.

Frederic (Harold), Novels by. Post 8vo, illust. boards, 2s, each. Beth's Brother's Wife.

The Lawton Girl.

French Literature, A History of. By Henry Van Laun, Three Vols., demy $8 v 0$, cloth beards, $7 s$. 6 , each.

Friswell (Hain).--One of Two: A Novel. Post 8vo, illust. bds., 2s.

Frost (Thomas), Works by. Crown $8 v o$, cloth extra, $3 s .6 d$. each. Circus Life and Circus Celebritles, | Llves of the Conjurers. The oid Showmen and the Oid London Fairs.

Fry's (Herbert) Royal Guide to the London Charities. Edited by JoHN LaANe. Published Anutually. Crown 8vo, cloth, ys. 6a.

Gardening Books. Post 8 vo, is. each; cloth limp. is. 6d. each.

A Year's Work in Garden and Greenhouse. By GEORGE GLFNNY.

Household Horticulture. By TOM and JANE JERROLD. lllustrated.

The Garden that Pald the Rent. By TOM JERROLD.

My Garden Wild. By Francis G. HeATh. Crown sve, cloth extra, 6 .

Gardner (Mrs. Alan).-Rifle and Spear with the Rajpoots : Being the Narrative of a Winter's Travel and Sport in Northern India. With numerous lllustrations by the Aathor and F. H. TOWNSEND. Demy 4 to, half-bound, 2 rs.

Garrett (Edward).- The Capel Girls: A Novel. Crown 8vo, cloth extra, with two Illustrations, $3 s .6 d$. ; pest $8 v 0$, illustrated boards, $2 s$.

Gaulot (Paul).-The Red Shirts: A Story of the Revolution. Translated by JOHN DE VILLIERS. With a Frontispiece by STANLEY WOOD. Crown 8vo, cleth, 35. 6d.

Gentleman's Magazine, The. Is, Monthly. Contains Stories, Articles upon Literature, Science, Biegraplay, and Art, and 'Table Talk' by SYLVANUS URBAN. ** Boutud Volumes for recent years kept int stock, 8s. 6d. each. Cases for bivding, 3s.

Gentleman's Annual, The. Published Annually in November. Is. German Popular Stories. Collected by the Brothers Grimm and Translated by EDGAR TAYLOR. With Introduction by JOHX RUSKIN, and 22 Stecl Plates after GRORGE CRUIKSHANK. Square 8vo, cloth, $6 s$, $6 t$, ; gilt edges, $7 s .6 d$.

Gibbon (Charles), Novels by.

Crown $8 v 0$, cloth extra, 35.6 . each; post 8 vo, illustrated boards, 25 . each.

Robin Gray. Frontispiece. I The Golden Shaft. Frontispiece. I LoxIng a Dream.

Pest 8vo, illustrated boards, $2 s$. each.

The Flower of the Forest.

The Dead Heart.

For Laok of Gold.

What Will the World Say?

For the King. I A Hard Knot.

Queen of the Meadow.

In Pastures Green.

In Loye and War.

A Heart's Problem.

By Mead and Stream.

The Braes of Yarrow.

Fancy Free. I Of HIgh Degree.

In Honour Bound.

Heart's Delight. ; Blood-Money.

Gibney (Somerville).-Sentenced! Crown 8vo, Is.; cloth, Is. $6 d$.

Gilbert (W. S.), Original Plays by. In Three Series, 2s. $6 d$. each.

The FIRST SERIES contains: The Wicked World-Pygmalion and Galatea-Charity-The PrincessThe Palace of Truth-Trial by Jury.

The SRCOND SERIES : Braken Heurts-Engaged-Sweethearts-Gretchen-Dan'1 Druce-Tom Cobb - H.M.S. 'Pinafore '-The Sorcerer-The Pirates of Penzance.

The THIRD SERIES: Comedy and Tragedy-lioggerty's Fairy-Rosencrantz and GuildensternPatience-Princess Ida-The Mikado-Ruddigore-The Yeonen of the Guard-The GondeliersThe Mountebanks-Utopia.

Eight Original Comic Operas written by W. S. GILBBRT. Containlng: The Sorcerer-H.M.S. 'Pinafore'-The Pirates of Penzance-lolanthe-Patience-Priucess Ida-The Mikado-Trial by Jury. Demy 8 vo, cloth limp, 2s. 6 .

The Gilbert and Sullixan Blrthday. Book: Quetations for Every Duy In the Year, selected

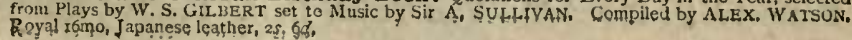


Gilbert (William), Novels by. Dr. Austin's Guests.

The Wizard of the Mountain.
Post 8vo, illustrated bds., 2s, each.

James Duke, Costermonger.

\section{Glanville (Ernest), Novels by.}

Crown $8 v 0$, cloth extra, $35.6 d$, each; post 8 vo, illustrated boards, 25 , each.

The Lost Heiress : A Tale of Love, Battle, and Adventure. With Twolllustrations by H. NISBET. The Fossicker: A Romance of Mashonaland. With Two lllustrations by HUME NISBET.

A Fair Colonist. With a Frontispiece by STANLEY WOOD.

The Golden Rock. With a Frontis. by STANLEY WOOD. Crown 8vo, cloth extra, $3^{s .6}$.

Glenny (George).-A Year's Work in Garden and Greenhouse : Practical Advice as to the Management of the Flower, Fruit, and Frame Garden: Post 8vo, 15.; cl. lp., 1s.6d. Godwin (William).-Lives of the Necromancers. Post $8 \mathrm{vo}, \mathrm{cl} ., 25$. Golden Treasury of Thought, The: An Encyclopædia of QUOTATIONS. Edited by THEODORE TAYLOK. Crown $8 \mathrm{vo}$, cloth gilt, 7s. $6 \%$.

Gontaut, Memoirs of the Duchesse de (Gouvernante to the Children of France), 1773-x836. With Two Photogravures. Two Vols., demy 8vo, cloth extra, 2rs.

Goodman (E. J.).--The Fate of Herbert Wayne. Cr. $8 \mathrm{vo}, 3^{5.6}$. Graham (Leonard).-The Professor's Wife: A Story. Fcp. 8vo, Is. Greeks and Romans, The Life of the, described from Antique Monuments. By ERNST GUHL and W. KONER, Edited by Dr. F. HUEFFER. With 54511115 trations. Large crown 8vo, cloth extra, 7s. 6d.

Greenwood (James), Works by. Crown 8vo, cloth extra, $3 s, 6 d$. each. The wilds of London.

Low-Life Deeps.

Greville (Henry), Novels by.

Nikanor. Translated by ELIZA E. CHASE. Post 8vo, illustrated boards, 2s.

A Noble Woman. Crown $8 v 0$, cloth extra, 55 . ; post 8 vo, illustrated boards, 25.

Griffith (Cecil).-Corinthia Marazion: A Novel. Crown 8vo, clotb extra, 35. 6ri. ; post 8vo, illustrated boards, 2s.

Grundy (Sydney).-The Days of his Vanity: A Passage in the Life of a Young Man. Crown $8 \mathrm{vo}$, clotl extra, $35.6 d$. ; post $8 \mathrm{vo}$, illustrated boards, $2 s$.

Habberton (John, Author of 'Helen's Babies '), Novels by.

Post 8vo, illustrated boards, 2s. each ; cloth limp, 2s. $6 d$, each.

Brueton's Bayou.

Country Luck.

Hair, The: Its Treatment in Health, Weakness, and Disease. Translated from the German of Dr. J. PINCUS. Crown 8vo, is.; cloth, 1s. 6 d.

Hake (Dr. Thomas Gordon), Poems by. Cr. 8vo, cl. ex., 6s, each. New Symbols.

Legends of the Morrow.

The Serpent Play.

Maiden Ecstasy. Small 4 to, cloth extra, 8s.

Hall (Owen).-The Track of a Storm. Crown 8vo, cloth, 6 s.

Hall (Mrs. S. C.).-Sketches of Irish Character. With numerous Illustrations on Steel and Wood by MACLISE, GILBERT, HARVEY, and GEORGE CRUIKSHANK. Small demy $8 v 0$, cloth extra, $75.6 d$.

Halliday (Andrew).-Every=day Papers. Post 8vo, boards, $2 s$.

Handwriting, The Philosophy of. With over 100 Facsimiles and Explanatory Text. By DON FELIX DE SALAmanCA. Post 8vo, cloth limp, 2s. 6r.

Hanky-Panky: Easy and Difficult Tricks, White Magic, Sleight of 11 and, \&c. Edited by W. H. CREMER. With 200 Illustrations. Crown 8vo, cloth extra, 45. 6d.

Hardy (Lady Duffus)._Paul Wynter's Sacrifice. Post 8vo, bds., 2s. Hardy (Thomas).-Under the Greenwood Tree. Crown 8vo, cloth extra, with Portrait and $x_{5}$ lllustrations, $35.6 d$.; post 8vo, illustrated boards, 25 . cloth limp, $25.6 d$.

Harper (Charles G.), Works by. Demy 8vo, cloth extra, r6s. each. The Brighton Road. With Photogravure Frontispiece and go lllustrations.

From Paddington to Penzance: The Record of a Summer Tramp. With ros Illustrations.

Harwood (J. Berwick).-The Tenth Earl, Fost 8 vo, boards, 2s, 
Harte's (Bret) Collected Works. Revised by the Author. LIBRARY

FDITION, in Eight Volumes, crown 8vo, cloth extra, 6s. each.

Vol. I. COMPLETE POETICAL AND DRAMATIC WORKS. With Stcel-plate Portralt.

"II. THE LUCK OF ROARING CAMP-BOHEMIAN PAPERS-AMERICAN LEGENDS.

"II. TALES OF THE ARGONAUTS-EASTERN SKETCHES.

"IV. GABRIEL CONROY. I Vol. V. STORIES-CONDENSED NOVELS, \&c.

"VI. TALES OF THE PACIFIC SLOPE.

" VII. TALES OF THE PACIFIC SLOPE-II, With Portrait by Jorin PeTTIE, R,A.

"VIII. TALES OF THE PINE AND THE CYPRESS.

The Select Worke of Bret Harte, in Prose and Poetry. With Introductory Essay by J. M. BELLEW, Portrait of the Author, and 50 Illustrations. Crown 8vo, cloth extra, $7 s .6 d$.

Bret Harte's Poetlcal Works. Printed on hand-Inade paper. Crown 8vo, buckram, 4s, 6d.

The Queen of the Plrate Isle. With 28 Original Drawings by KATE GREENAWAY, reproduced in Colours by EDMUND EVANS. Small 4 to, cloth, 5 .

Crówn 8vo, cloth extra, 3s. 6rt. each; post $8 v 0$, picture boards, 2s. each.

A Waif of the Plains. With 60 Illustrations by STANLEY L. Woon.

A Ward of the Golden Gate. With 59 lllustrations by STANLEY L. Wood.

$$
\text { Crown 8vo, cloth extra, 35. 6d, each. }
$$

A Sappho of Green Springs, \&c. With Two Illustrations by IIUME NISBET. Colonel Starbottle's Cllent, and Some Other People. With a Froutispiece.

Susy: A Novel. With Frontispiece and Vignette by J. A. CHRISTIR.

Saily Dows, \&ec. With 47 Illustrations by W. D. ALMOND and others.

A Protegee of Jack Hamlln's. With 26 Illustrations by W. SMALL and others.

The Bell-Ringer of Angel's, Sc. With 39 Illustrations by DUDLEY H ARDY and others.

Clarence: A Story of the American War. With Eight lllustrations by A. JULE GOODMAN.

Post 8 vo, illustrated boards, 2s. each.

Gabriel Conroy.

An Helress of Red Dog, sc.

The Luck of Roaring Camp, \&c.

Cajfornian Storles.

Post 8 vo, illustrated boards, 25. each ; cloth, 2s. 6i. each.

Elfp.

I Maruja.

A Phylis of the Blerras.

Snow-Bound at Eagle's.

Fcap. 8vo, plcture cover, rs. each.

Haweis (Mrs. H. R.), Works by.

The Art of Beauty. With Coloured Frontispiece and gr Illustrations. Square 8vo, cloth bds., $6 s$. The Art of Decoration. With Coloured Frontispiece and 74 Illustrations, Sq. 8vo, cloth bds., $6 s$, The Art of Dress. With 32 Illustrations. Post $8 v o, 1 s . ;$ cloth, $1 s .6 u$.

Chaucer for Schools. Demy 8 vo, cloth limp, 2s. 6 d.

Chaucer for Children. With $3^{8}$ Illustrations (8 Coloured). Crown 4to, cloth extra, $35.6 \%$.

Haweis (Rev. H. R., M.A.).-American Humorists: Washington IRVING, OLIVER WENDELL HOLMES, JAMES RUSSELL LOWELL, ARTEMUS WARD, MARK TWAIN, and BRET HARTE. Third Edition. Crown 8vo, cloth extra, 65 .

Hawthorne (Julian), Novels by.

Crown $8 v_{0}$, cloth extra, $35.6 \%$, each post $8 v o$, illustrated boards, as. each.

Garth. I Eljuce Quentin.

Sebastian Strome.

Fortune's Fool, | Dust. Four Il!usts.

Beatrix Randolph. With Four Illusts.

David Polndexter's Disappearance.

The Spectre of the Camera.

Post 8vo, illustrated boards, 2s, each.

Miss Cadogna.

Love-or a Name.

Mrs. Gainsborough's Dlamonds. I'cap. 8vo, illustrated cover, $x$ s.

Hawthorne (Nathaniel).-Our Old Home. Annotated with Passages from the Author's Note-hooks, and Illustrated with $3 x$ Photogravures. Two Vols., cr. 8vo, r5s.

Heath (Francis George).-My Garden Wild, and What I Grew There. Crown $8 v 0$, cloth extra, gilt edges, 6 s.

Helps (Sir Arthur), Works by. Post 8vo, cloth limp, 2s. 6d. each. Anlmals and their Masters. Social Pressure.

Ivan de Biron: A Novel. Crown 8 vo, cloth extra, $3 s .6 d$; post 8 vo; illustrated boards, $2 s$.

Henderson (Isaac). - Agatha Page: A Novel. Cr. 8vo, cl., 35. $6 d$.

Henty (G. A.), Novels by. Crown 8vo, cloth extra, 35. $6 d$. each. Rujub the Juggler. With Eight Illustrations by STANLEY L. WOOD. Dorothy's Double.

Herman (Henry).-A Leading Lady. Post 8vo, bds., 2s. ; cl, , 2s. $6 d$.

Herrick's (Robert) Hesperides, Noble Numbers, and Complete Collected Poems. With Memorial-Introduction and Notes by the Rcv. A. B. GROSART, D.D., Steel Portrait, \&c. Three Vois., crowa 8vo, cloth boards, 18 s. 
Hertzka (Dr. Theodor).-Freeland: A Social Anticipation. Translated by ARTHUR RANSOst. Crown 8vo, cloth extra, 65 .

Hesse-Wartegg (Chevalier Ernst von).-Tunis : The Land and the People. With 22 Illustrations. Crown $8 v 0$, cloth extra, $3^{s} .6 d_{\text {. }}$

Hill (Headon).-Zambra the Detective. Post 8vo, bds., 2s.;cl., 2s. $6 d$.

Hill (John), Works by.

Treason-Felony. Post $8 v 0$, boards, 2s. | The Common Ancestor. Cr. 8vo, cloth, 3s, 6d.

Hindley (Charles), Works by.

Tayern Anecdotes and Sayings: Including Reminiscences connected with Coffce Houses, Clubs, \&c. With Illustrations. Crown $8 v_{0}$, clotli extra, $35.6 \%$.

The Life and Adventures of a Cheap Jack. Crown 8vo, cloth extra, 35. $6 a$.

Hodges (Sydney). - When Leaves were Green. 3 vols., I5s. net. [Shortly. Hoey (Mrs. Cashel).-The Lover's Creed. Post 8vo, boards, $2 s$.

Hollingshead (John).-Niagara Spray. Crown 8vo, Is.

Holmes (Gordon, M.D.) - The Science of Voice Production and Yolce Preseryation. Crown $8 v 0$, is.; cloth, is. $6 d$.

Holmes (Oliver Wendell), Works by.

The A utocrat of the Breakfast-Table. 1llustrated by J. GORDON THOMSON. Post 8vo, cloth limp, 2s. 6d.-Another Edition, post 8vo, cloth, 2s.

The Autocrat of the Breakfast-Table and The Professor at the Breakfast-Table. In One Vol. Post 8vo, balf-bound, 25 .

Hood's (Thomas) Choice Works in Prose and Verse. With Life of the Author, Portrait, and 200 Illustrations. Crown 8 ro, cloth extra, 75. 6d. Hood's Whims and Oddities. With 85 Jllustrations. Post 8 vo, half-bound, 25.

Hood (Tom).-From Nowhere to the North Pole: A Noah's Arkæological Narrative. With 25 lllustrations by W. BRUN7ON and E. C. BARNES. Cr. 8vo, cloth, 6s,

Hook's (Theodore) Choice Humorous Works; including his Ludicrous Adventures, Bons Mots, Puns, and Hoaxes. With Life of the Author, Portraits, Facsimiles, and Jllustrations. Crown $8 \mathrm{vo}$, cloth extra, $79.6 d$.

Hooper (Mrs. Geo.).-The House of Raby. Post 8vo, boards, 25. Hopkins (Tighe).- 'Twixt Love and Duty.' Post 8vo, boards, $2 s$. Horne (R. Hengist).-Orion: An Epic Poem. With Photograph Portrait by SUMMERS. Testh Edition. Crown 8vo, cloth extra, 75.

Hungerford (Mrs., Author of 'Molly Bawn'), Novels by.

Post 8vo, illustrated boards, 25, each; cloth limp, 2s. $6 d$. each.
A Malden All Forlorn.
Maryel.
In Durance Y1le.
A. Modern circe.
A Mental Strugsle.
Crown 8vo, cloth extra, 3s, 6d, each.

The Red-Fouge Mystery.

I The Three Graoes, With 6 Illusts.

[Shortly.

Lady Yerner's Flight. Crown 8vo, cloth, 3s. 6\%.; post 8vo, 1llustrated boards, 25.

The Professor's Experlment. Three Vols., crown 8vo, $15 s$. net.

Hunt's (Lelgh) Essays: A Tale for a Chimney Corner, \&c. Edited by EDMUND OLLIER. Post 8vo, half-bound, 25 .

Hunt (Mrs. Alfred), Novels by.

Crown 8 vo, cloth extra, 35. 6 , each; post 8 vo, llustrated boards, 25, each.

The Leaden Casket. | Self-Condemned, | That Other Rorson.

Thornlcroft's Model. Post 8vo, boards, 2s. I Mrs. Juliet. Crown 8vo, cloth extra, 3s. 6d.

Hutchison (W. M.).-Hints on Colt-breaking. With 25 Illustrations. Crown 8vo, cloth extra, 35. 6d.

Hydrophobia : An Account of M. PASTEUR's System ; The Technique of his Method, and Statistics. By RBNAUD SUZOR, M.B. Crown 8vo, cloth extra, 6 s.

Hyne (C. J. Cutcliffe).- Honour of Thieves. Cr. 8vo, cloth, 3 s. $6 d$. Idler (The): An Illustrated Magazine. Edited by J. K. TERome. $6 d$. Monthly, The First SEVEN VOLS, are now ready, cloth extra, 55 . each; Cascs for Binding, Is, $6 d$, each. 
Impressions (The) of Aureole. Crown 8vo, printed on blush-rose paper and handisomely bound, $6 s$.

Indoor Paupers. By One of Them. Crown $8 \mathrm{vo}$, is. ; cloth, is. $6 d$. Ingelow (Jean).-Fated to be Free. Post 8vo, illustrated bds., 2s.

Innkeeper's Handbook (The) and Licensed Victualler's Manual. By J. TRRVOR-DAVIES. Crown 8vo, is. ; cloth, is. $6 d$.

Irish Wit and Humour, Songs of. Collected and Edited by A. PERCEVAL GRaves. Post 8vo, cloth limp, 2s. $6 d$.

Irving (Sir Henry) : A Record of over Twenty Years at the Lyceum. By PERCY Fitzger ALD. With Portrait. Crown 8vo, 1s.; cloth, Is. 6r.

James (C. T. C.). - A Romance of the Queen's Hounds. Post $8 v 0$, picture cover, $x s$. ; cloth limp, is. $6 d$.

Jameson (William).-My Dead Self. Post 8vo, bds., 2s. ; cl., 2s, $6 d$. Japp (Alex. H., LL.D.).-Dramatic Pictures, \&c. Cr. 8vo, cloth, 5s. Jay (Harriett), Novels by. Post $8 \mathrm{vo}$, illustrated boards, $2 s$. each. The Dark Colleen. I The Queen of Connaught.

Jefferies (Richard), Works by. Post 8vo, cloth limp, 2s. 6d. each. Nature near London. | The Life of the Elelds. | The Open Alr.

*** Also the HAND-MADE PAPER EDITION, crown 8vo, buckram, gilt top, 6s. cacl.

The Eulogy of Richard Jefferies. By Sir WALTER BESANr. With a Photograph. Portrait. Crown 8vo, cloth extra, 6 .

Jennings (Henry J.), Works by.

Curiosities of Criticlsm. Post 8 vo, cloth limp, 2s, 6 d.

Lord Tennyson: A Biographical Sketch. With 1'ortrait. Post 8vo, Is, ; cloth, Is, 6r.

Jerome (Jerome K.), Books by.

Stageland. With 64 Illustrations by J. BERNARD PARTRIDGE. Fcap. 4to, picture cover, 15.

John Ingerfleld, \&c. With 9 lllusts, by A. S. BOYD and JOHN GULICH. licap. 8vo, pic. cov. Is. $6 d$.

The Prude's Progress: A Comedy by J. K. JEROME and EDEN PHILLPO'TS. Cr. 8vo, is. 6d.

Jerrold (Douglas).-The Barber's Chair; and The Hedgelıog Letters. Post 8 vo, printed on laid paper and half-bound, $2 s$.

Jerrold (Tom), Works by. Post 8vo, Is. ea. ; cloth limp, Is. 6d. ea. The Garden that Paid the Rent.

Household Horticulture: A Gossip about Flowers. Illustrated.

Jesse (Edward).-Scenes and Occupations of a Country Life. Post 8vo, cloth limp, 2s.

Jones (William, F.S.A.), Works by. Cr. 8vo, cl. extra, 7s. 6d. ea.

Finger-Ring Lore: Historical, Legendary, and Anecdotal. With nearly 300 1liustrations. Second Edition, Revised and Enlarged.

Credulities, Past and Present. Including the Sea and Seamen, Miners, Talismans, Word and Letter Divination, Exorcising and Blessing of Animals, Birds, Eggs, Luck, Sic. With Froutispiece. Crowns and Coronations: A History of Regalia. With roo lilustrations.

Jonson's (Ben) Works. With Notes Critical and Explanatory, and a Biographical Memolr by WILLIAM GrFForD. Edited by Colonel CUNNINGIAM. Three Vols. crown 8vo, cloth extra, 6s. each.

J osephus, The Complete Works of. Translated by Whrston. Containing 'The Antiquities of the Jews' and 'The Wars of the Jews.' With 52 Jllustrations and Maps. Two Vols., demy 8vo, half-bound, 12s. $6: t$

Kempt (Robert).-Pencil and Palette: Chapters on Art and Artists. Post 8 vo, cloth limp, 2s. $6 d$.

Kershaw (Mark). - Colonial Facts and Fictions: Humorous Sketches. Post 8 vo, illustrated boards, 2s.; cloth, $2 s, 6 d$.

Keyser (Arthur).--Cut by the Mess. Crown 8vo, Is. ; cloth, is. $6 d$. King (R. Ashe), Novels by. Cr. $8 v o$, cl., 3s. $6 d$. ea.; post $8 v o$, bds., $2 s$. ea. A. Drawn Game. 'Tho Wearing of the Green.'

Passion's Siaya.

Post Evo, illustrated boards, 2s. each.

Bell Barry. 
Knight (William, M.R.C.S., and Edward, L.R.C.P.). - The Patient's Yade mecum: How to Get Mlost Benefit froun Medical Advice. Cr. 8vo, is.; cl, rs. $6 d^{\circ}$

Knights (The) of the Lion: A Romance of the Thirteenth Century. Edited, with an Introduction, by the MARQUESS OF LORNE, K.T. Crown 8vo, cloth extra, 6s.

Lamb's (Charles) Complete Works in Prose and Verse, including 'Poetry for Children and 'Prince Dorus.' Edited, with Notes and Introduction, by $R$. $H$. SHEP. HERD. With Two Portraits and Facsimile of the 'Essay on RoastPig.' Crown 8vo, half-bd., $7 s .6 d$. The Essays of Ella. Post 8vo, printed on laid paper and half-bound, 25.

Little Essays: Sketches and Characters by CHARLES LAMB, selected from his Letters by PERCY FITZGERALD. Post 8vo, cloth limp, 2s, 6d.

The Dramatic Essays of Charles Lamb. With Introduction and Notes by BRANDER MAT. THEWS, and Steel-plate Portrait. Fcap. 8vo, half-bound, 2s. $6 d$.

Landor (Walter Savage).-Citation and Examination of William Shakspeare, \&c., before Sir Thomas Lucy, touching Deer-stealing, 19th September, r582. To which is added, $\boldsymbol{A}$ Conference of Master Edmund Spenser with the Earl of Essex, touching the State of Ireland, 1595. F cap. 8vo, half-Roxburghe, 25. $6 d$.

Lane (Edward William).-The Thousand and One Nights, commonly called in England The A rablan NIghts' Entertainments. Translated from the Arabic, with Notes. Illustrated with many hundred Engravings from Designs by HARVEY. Edited by EDWARD Stanley POOLE. With Preface by STANLEY LANe-POOLE. Three Vols, demy $8 v 0$, cloth, 75 . $6 d$. ea.

Larwood (Jacob), Works by.

The Story of the London Parks. With Illustrations. Crown 8vo, cloth extra, 3s. 602

Aneodotes of the Cler\$y. Post 8vo, laid paper, half-bound, 25.

Post 8vo, cloth limp, 2s. 6 d. each.

Forensic Anecdotes,

Theatrical Anecdotes.

Lehmann (R. C.), Works by. Post 8vo, Is. each; cloth, 1s. 6d. each. Harry Fludyer at Cambridge.

Conyersational Hints for Young Shooters: A Guide to Polite Talk.

Leigh (Henry S.), Works by.

Carols of Cockayne. Printed on hand-made paper, bound in buckram, 5 .

Jeux d'Esprit. Edited by HENRY S. LEIGH. Post 8 vo, cloth limp, $25.6 d$.

Lepelletier (Edmond). - Madame Sans=Gène. Translated from the French by JOHN DE VILLIERS. Crown 8vo, cloth extra, 3s. $6 d$.

Leys (John).-The Lindsays: A Romance. Post 8vo, illust.bds., 2s.

Lindsay (Harry).--Rhoda Roberts : A Welsh Mining Story. Crown 8 vo, cloth, 3s. $6 d$.

Linton (E. Lynn), Works by. Post 8vo, cloth limp, 2s, $6 d$. each. witch Stories.

Crown 8vo, cluth extra, 3s. 6d, each; post 8vo, illustrated boards, 2s. each.

Patricla Kemball. J Ione.

The Atonement of Leam Dundas.
The World Well Lost. With r2 Illusts.

Under whlch Lord ? With ra Illustrations.

'My Loye?"

Sowing the Yind.

Paston Carez, Millionaire and Miser.

Post 8vo, illustrated boards, 2s each.

The Rebel of the Famlly.

With a suken Thread.

The One Too Many. Crown 8vo, cloth extra, 35. $6 d$

Dulcle Exerton. Two Vols, crown 8vo, ros. net.

[Shortly.

Freeshooting : Extracts from the Works of Mrs. LYNN LINTON. Post 8vo, cloth, 2s. 6 d.

Lucy (Henry W.).-Gideon Fleyce: A Novel. Crown 8vo, cloth extra, 3s. 6 d. ; post 8vo, illustrated boards, 2s.

Macalpine (Avery), Novels by.

Teresa Itasca. Crown $8 v 0$, cloth extra, is.

Broken Wings. With Six Illustrations by W. J. HeNNESSY. Crown 8vo, cloth extra, $6 s$.

MacColl (Hugh), Novels by.

Mr. Stranger's Sealed Packet. Post 8vo, illustrated boards, 2s.

Ednor Whitlock. Crown 8vo, cloth extra, $6 s$.

Macdonell (Agnes), -Quaker Cousins. Post 8vo, boards, 2s.

MacGregor (Robert).-Pastimes and Players : Notes on Popular Games. Post 8vo, cloth limp, 2s. $6 d$.

Mackay (Charles, LL.D.). - Interitudes and Undertones; or, Music at Twilight. Crown 8ro, cloth extra, 6 s. 
McCarthy (Justin, M.P.), Works by.

A History of Our Own Times, from the Accession of Queen Victoria to the General Flection of r880. Four Vols., demy 8 vo, cloth extra, 12s. each. - Also a POPULAR EDITION, in Four Vols., crown 8 vo, cloth extra, 6s. each. $\rightarrow$ And the JUBILEE EDITION, with an Appendix of Events to the end of $\mathbf{x} 886$, in Two Vols, , large crown $8 \mathrm{vo}$, cloth extra, $75.6 \mathrm{~d}$, each.

A Short History of Our Own Times. One Vol, crown 8ro, cloth extra, 6s,-Also a CHEAP POPUlar EDIrton, post 8vo, cloth limip, as. $6 d$.

A History of the Four Georges. Four Vols, demy $8 \mathrm{vo}, \mathrm{cl}$, ex, 12s. each. [Vols. I. \& II. ready. Crown $8 v 0$, cloth extra, 35. 6d. each; post 8vo, illustrated boards, 25 . each; cloth limp, $2 s .6 d$, each.

The Waterdale Nelghbours.

My Enemy'g Daughter.

A Falr Saxon.

Linley Rochford.

Dear Lady Disdain,

Iiss Misanthrope. With 12 Iilustrations. Red Dlamonds.

'The Right Monourable.' By JUSTIN MCCARTiY, M.P., and Mrs. CAMPBell PRAed. Crown 8 vo, cloth extra, $6 s$.

McCarthy (Justin Huntly), Works by.

The French Revolution, (Constituent Assembly, r780-9r). Four Vols., demy 8vo, cloth extra, 12s, Vols. 1. \& II. ready: Vols. III. \& IV. in the press.

An Outline of the History of Ireland. Crown 8vo, 15.; cloth, Is. 6 .

Ireland Since the Union: Sketches of Irish History, 1798-1886. Crown 8vo, cloth, 65.

Haflz in London: Poems, Smatl 8vo, gold cloth, 3 s. $6 d$.

Our Sensation Novel. Crown 8 vo, picture cover, 15. ; cloth limp, $15.62 \%$

Doom: An Atlantic Episode. Crown 8vo, picture cover, is.

Doliy: A Sketch. Crown 8vo, picture cover, $x$ s.: cloth limp, is. 6 d.

Lily Lass: A Romance. Crown 8 vo, picture cover, 15 . ; cloth limp, $15.6 d$.

The Thousand and One Days. With Two Phdtogravures. Two Vols., crown 8vo, half-bd., I2s.

A London Legend. Crown 8 vo, cloth, 3 s. $6 d$.

[Shortly,

MacDonald (George, LL.D.), Books by.

Works of Fancy and Imagination. Ten Vols., 16mo, cloth, gilt edges, in cloth case, 21s. ; or the Volumes may be had separately, in Grolier cloth, at $25.6 \mathrm{~d}$. each.

Vol. I. WITHIN AND WITHOUT.-THE HIDDEN LIFE.

" II. THE DISCIPLE.-THE GOSPEL WOMEN.-BOOK OF SONINETS.-ORGAN SONGS.

"III. VIOLIN SONGS.-SONGS OF THE DAYS AND NIGHTS.-A BOOK OF DREAMS. -ROADSIDE POEMS.-POEMS FOR CHILDREN.

"IV. PARABLES.-BALLADS.-SCOTCH SONGS.

"V. \& VI. PHANTASTES: A Faerie Romance. I Vol. VII. THE PORTENT.

"viII. THE LigHT PRINCESS. - THE GIANT'S HEART. -SHADOWS.

"IX. CROSS PURPOSES. -THE GOLDEN KEY.-THE CARASOYN,-I.ITTLE DAYLIGHT

" X. THE CRUEl PAINTER.-THE WOW O' RIVVEN. -THE CASTLE.-THE BROKEN SWORDS, -THE GRAY WOLF.-UNCLE CORNELIUS.

Poetical Works of George MacDonald. Collected and Arranged by the Author. Two Vols. crown 8 vo, buckram, 12s.

A Threetold Cord. Edited by George MaCDonald. Post 8vo, cloth, 5 s.

Phantastes: A Faerie Romance. With 25 Illustrations by J. BELL. Crowa 8vo, cloth extra, $35.6 d$. Heather and Snow: A Novel, Crown 8vo, cloth extra, $35.6 x$.

Lllith: A Romance. Crown 8vo, cloth extra, $6 s$.

Maclise Portrait Gallery (The) of Illustrious Literary Charac * ters : 85 Portralts by DANizL MACLISE; with Memoirs-Biographical, Critical, Bibliographical, and Anecdotal-illustrative of the Literature of the former half of the Present Century, by WILLIAM BATES, B.A. Crown 8vo, cloth extra, 75.6d.

Macquoid (Mrs.), Works by. Square 8vo, cloth extra, 6s. each. In the Ardennes. With 50 llustrations by THOMAS R. MIACQUOID. Plotures and Legends erom Normandy and Brittany. 34 lilusts. by T, R, MACQUOID. Through Normandy. With 92 lllustrations by T. R. MACQUOID, apd a Map.

Through Brlttany, With 35 Illustrations by T, R. MACQUOID, and a Map.

A bout Yorkshire. With 67 llustrations by T. R. MIACQUOID.

Post 8 vo, illustrated boards, $2 s$. cach.

The Exil Eye, and other Stories.

Lost Rose, and other Stories.

Magician's Own Book, The: Performances with Eggs, Hats, \&c. Edited by W. H. CREMER. With 200 Illustrations. Crown $8 v o$, cloth extra, 45. $6 d$.

Magic Lantern, The, and its Management : Including full Practical Directions. By T. C. HEPwORTH. With ro Illustrations. Crown 8vo, 2s. ; cloth, 1s. $6 d$.

Magna Charta: An Exact Facsimile of the Original in the British Museum, 3 feet by 2 feet, with Arms and Seals emblazoned in Gold and Colours, $5 s$.

Mallory (Sir Thomas). - Mort d'Arthur: The Stories of King Arthur and of the Knights of the Round Table. (A Seleçtion.) Edited by B. MONTGOMERIE RANXING, Post $8 \mathrm{vo}$, cloth limp, 2s, 
Mallock (W. H.), Works by.

The New Republic. Post 8vo, picture coter, 2s. ; cloth limp, 2s. 6r.

The New Paul \& Yirsinla: Positivism on an Island. Post $8 v 0$, cloth, 2s, 6d.

A Romance of the Nineteenth Century. Crown $8 v 0$, cloth 6 s. ; post $8 v 0$, illust. boards, 2s

Poems. Small 4to, parchment, 8 s.

Is Lifo Worth Living? Crown 8 vo, cloth extra, $6 s$.

Mark Twain, Books by. Crown 8 vo, cloth extra, $7 s .6 d$. each.

The Cholce Works of Mark Twain. Revised and Corrected throughout by the Author. With Life, Portrait, and numerous Illustrations.

Roughing It ; and The Innocents at Home. With 200 Illustrations by F. A. FR.ASER.

Mark Twain's Library of Humour. "With rg7 Illustrations.

Crown 8vo, cloth extra (illustrated), 7s. 6d. each ; post 8vo, illustrated boards, 2s. each.

The Innocents Abroad; or, The New Pilgrim S Progress. With 234 Illustrations. (Tho Two Shit. ling Edition is entitled Mark Twain's Pleasuro Trip.)

The GlIded Age. By MARK TWAIN and C. D. WARNER. Witl 212 Illustrations.

The Adventures of Tom Sawyer. With rxx Illustrations.

A Tramp Abroad. With 374 llustrations.

The PrInce and the Pauper. With Ign Illustrations.

Life on the Mississippl. With 300 lllustrations.

The Adventures of Huckleberry Finn. With 14 Illustrations by E, W. KRMLR.

A. Yankee at the Court of IKIng Arthur. With \&20 Illustrations by DAN BEARD.

Crown 8vo, eloth extra, 3s, 6d, each.

The American Claimant. With 8 I Illustrations by HAL. HuRst and others.

Tom Sawyer Abroad. With 26 Illustrations by DAN. BEARD.

Pudd'nhead WIIson. With Portrait and Six Illlustrations by LouIS LoRB.

Tom Sawyer, Detective, \&ec. With numerous lllustrations.

[Stority.

The \&1,000,000 Bank-Note. Crown 8vo, cloth, 3s. 6d.; post 8vo, picture boards as.

Post 8 vo, illustrated boards, 25 , each.

The Stolen White Elephant. I Mark Twain's Sketches,

Marks (H. S., R.A.), Pen and Pencil Sketches by. With Four Photogravures and 126 Illustrations. Two Vols. demy $8 v 0$, cloth, $32 s$.

Marlowe's Works. Including his Translations, Edited, with Notes and Introductlons, by Colonel CUNNINGHAM. Crown 8vo, cloth extra, 6 s.

Marryat (Florence), Novels by. Post 8vo, illust. boards, 2s. each. A Haryest of Wild Oats. Open! Sesame!

\section{Fighting the Air.}

Written in Fire.

Massinger's Plays. From the Text of William Gifford. Edited by Col. CUNNingham. Crown 8 vo, cloth extra, 6 .

Masterman (J.).-Half=a=Dozen Daughters. Post 8vo, boards, $2 s$. Matthews (Brander).-A Secret of the Sea, \&c. Post $8 \mathrm{vo}$, illustrated boards, $2 s$. ; cloth limp, 2s. $6 d$.

Mayhew (Henry).-London Characters, and tlie Humorous Side of London Life. With numerous Illustrations, Crown $8 v 0$, cloth, $35,6 z$.

Meade (L. T.), Novels by. Crown $8 v o$, cloth, 3s. $6 d$. each. A Soldier of Fortuna. I In an Iron Grip.

The Yolce of the Charmer. Three Vols., I5s. net.

Merrick (Leonard).-The Man who was Good. Post 8vo, illus. trated boards, 25 .

Mexican Mustang (On a), through Texas to the Rio Grande. By A. E. SWEE'T and J. ARMOY KNOX With 265 Illustrations. Crown 8vo, cloth extra, $75.6 \%$.

Middlemass (Jean), Novels by. Post 8vo, illust. boards, 2s, each. Touch and Co.

Miller (Mrs. F. Fenwick).-Physiology for the Young; or, The House of Life. With numerous Illustrations. Post $8 v o$, cloth limp, $2 s .6 d$.

Milton (J. L.), Works by. Post 8vo, Is. each; cloth, Is. $6 d$. each. The Hyglene of the Skin. With Directions for Diet, Soaps, Baths, Wines, \&c.

The Bath in Diseases of the Skin.

The Laws of Life, and thelr Relation to Diseases of the Skin.

Minto (Wm.).-Was She Good or Bad? Cr. $8 v 0$, Is.; cloth, Is, 6d. 
Mitford (Bertram), Novels by. Crown 8vo, cloth extra, 3s. 6d. each. The Cun-Runner: A Romance of Zululand. With a Frontisplece by STANLEY I.. WOOD. The Luck of Gerard Rid galey. With a Frontispiece by STANLEY L. WOOD. The King's Assegai. With Six full-page Illustrations by STANLEY L. WOOD. Renshay Fanning's Quest. With a Frontispiece by STANLEY L. WOOD.

Molesworth (Mrs.), Novels by.

Hathercourt Rectory.' Post 8 vo, illustrated boards, as.

That Girl in Black. Crown 8vo, cloth, $1 s .6 \%$.

Moncrieff (W. D. Scott=).-The Abdication : An Historical Drama. With Seven Etchings by JOHN PETTIE, W. Q. ORCHARDSON, J. MACWIfIRTER, COLIN HUNTER, R. MACBETH and TOM GRAHAM, Imperial 4to, buckran, $21 s$.

Moore (Thomas), Works by.

The Eplcurean; and Alciphron. Post 8vo, half-bound, 2s.

Prose and Yerse; including Suppressed Passages from the MrMoIrs of LORD BYRON, Edited by R. H. SHEPHERD. With Portrait. Crown 8 vo, cloth extra, $7 s .6 \mathrm{~d}$.

Muddock (J. E.) Stories by.

Stories Welrd and Yonderful. Post $8 \mathrm{vo}$, illustrated boards, 2s. ; cloth, as. $6 d$.

The Dead Man's Secret. Frontispiece by F. BARNARD. Cr. 8vo, cloth, 5s.; post $8 v 0$, boards, $2 s$. From the Bosom of the Deep. Post 8 vo, illustrated boards, 25 .

Maid Marian and Robin Hood. With r2 Illusts, by STANLEY WooD. Cr. $8 v 0$, cloth extra. 35.62 . Basile the Jester. Crown 8vo, cloth, $35,6 d$.

Murray (D. Christie), Novels by.

Crown $8 v 0$, cloth extra, 35.6 . each ; post $8 \mathrm{vo}$, illustrated boards, ss. each.

A Life's Atonement. The Yay of the world. Joseph's Coat. ra lliusts. Coals of Fire. 3 Illusts.

Yal Strango.

Hearts.

The Way of the Old Blazer's Hero.

Cynic Fortune. Frontisp.

By the Gate of the Sea.

[Shortly.

In Direst Peril.

Crown $8 v 0$, cloth extra, 35, 6d. each.

The Making of a Noxelist: An Experiment in Autobiograplyy. With a Collotypo Portrait and Vignette. Crown 8 vo, art linen, 6 s.

Murray (D. Christie) and Henry Herman, Novels by. Crown $8 v 0$, cloth extra, 35. 6 . each ; post 8vo, illustrated boards, 2s. each.

One Trayeller Returns. The Bishops' Bible.

Paul Jones's Alias, \&c. With lllustrations by A. FORESTIER and G. NICOLET.

Murray (Henry), Novels by.

A Game of Blufr.

Post $8 \mathrm{vo}$, illustrated boards, 2s, each; cloth, 2s. $6 d$. each.

Newbolt (Henry).-Taken from the Enemy. Fcp. 8vo, cloth, Is. 6d.

Nisbet (Hume), Books by.

'Bail Up.' Crown 8 vo, cloth extra, $3 s .6$. : post $8 \mathrm{vo}$, illustrated boards, $2 s$.

Dr. Bernard St. Yincent. Post $8 v o$, illustrated boards, $2 s$.

Lessons In Art. With ar Illustrations. Crown 8vo, cloth extra, 2s. $6 d$.

Where Art Begins, With 27 Illustrations. Square 8vo, cloth extra, $7 s .6 d$.

Norris (W. E.), Novels by. Crown 8vo, cloth, 3s. 6d. each. Saint Ann's. 1 Billy Bellow. With Frontispiece.

[Shortly.

O'Hanlon (Alice), Novels by. Post 8 vo, illustrated boards, 2s. each. The Unforeseen.

1 Chance? or Fate?

Ouida, Novels by. Cr. 8 vo, cl., 3s. $6 d$. ea.; post 8 vo, illust. bds., $2 s$. ea Held In Bondage.

Tricotrin.

Strathmore.

Chandos.

Cecil Castlemaine's Cage

Under Two Flags.

Pack. | Idalia.

Folle-Farine.

F Dog of Flanders.

Pascarel. I Signa,

Two Wooden Shoes.

In a Yinter City.

Arladine.

Friendship.
Moths. I Pipistrello. A Yillage Commune. In Maremma. I Yanda. Bimbl. | Syrlin. Frescoes. | Othmar. Princess Napraxlne. Gullderoy. I Rufino.

BImbl. With Nine Illustrations by EDMUND Il. GARRETT.

A Dog of Flanders, \&c. With Six Illustrations by EDMUND H. GARRETT.

Santa Barbara, \&c. Square 8vo, cloth, 6s.; crown 8vo, cloth, 3s. 6d. ; post 8vo, illustrated boards, $2 s$. Two Offenders. Square $8 v 0$, cloth extra, 65 . ; crown $8 v o$, cloth extra, $35.6 d$.

Wisdom, Yit, and Pathos, selected from the Works of OUIDA by F, SYDNEY MORBIS. POst

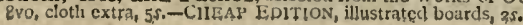


Olinet (Georges), Novels by. : Post Svo, illustrated boards, 2s, each. Doctor Rameau.

I A Last Love.

A Welrd Gift. Crown 8vo, cloth, 3 s. $6 d$.; post $8 \mathrm{vo}$, picture boards, 25 .

Oliphant (Mrs.), Novels by. Post $8 v o$, illustrated boards, 2s, each. The Primrose Path.

The Greatest Helress in England.

O'Reilly (Mrs.).-Phcebe's Fortunes. Post 8vo, illust. boards, 25.

Page (H. A.), Works by.

Thoreau: His Life and Aims. With Portrait. Post 8vo, cloth limp, 2s. 6d.

Antmal Anecdotes. Arranged on a New Principle. Crown 8vo, cloth extra, 55.

Pandurang Hari; or, Memoirs of a Hindoo. With Preface by Sir BARTLE FRERE. Crown 8vo, cloth, 3.5. 6 \%.; post 8vo, illustrated boards, 25.

Pascal's Provincial Letters. A New Translation, with Historical Introduction and Notes by T. M'CRIE, D.D. Post 8vo, cloth limp, 25.

Paul (Margaret A.).-Gentle and Simple. Crown 8vo, cloth, with Frontispiece by HELEN PATERSON, $35,6 \%$; post 8 vo, illustrated boards, $2 s$.

Payn (James), Novels by.

Crown 8 vo, cloth extra, 35.6 . each; post 8 ro, illustrated boards, 25, each.

Lost Sir Massingberd.

Walter's Word.

Less Black than We're Painted.

By Proxy. J For Cash Only.

High Splrits.

unaer Une Root.

A Confiential A gent. With 12 Illusts.

A Grape from a Thorn. With 12 Illusts.
Hollday Tasks.

The Canon's Ward. With Portrait.

The Talk of the Town. With 12 lllusts.

Glow-Worm Tales.

The Mystery of Mirbridge.

The Word and the Will.

The Burnt Million.

Sunny Stories. ।

A Trying Patlent.

Post 8vo, illustrated boards, 2s, each.

Humorous Storles. I From Exlle.

The Foster Brothers.

The Famlly Scapegrace.

Married Beneath Him.

Bentlnck's Xutor.

A Perfect Treasure.

A County Famlly.

Like Father, Like Son.

A Woman's Yengeance.

Carlyon's Year. | Cecl's Tryst.

Murphy's Master.

At Her Mercy.

The Clyfrards of clyfie.

Peril and Privation.

Notes from the 'News.'
Found Dead.

Gwendoline's Farrest.

A Marlne Resideuce.

Mirk Abbey.

Some Private Ylews.

Not Wooed, But Won.

Two Hundred Pounds Reward.

The Best of Husbands.

Halyes.

Fallen Fortunes.

What He Cost Her.

Kit: A Memory.

A Prince of the Elood.

Pennell (H. Cholmondeley), Works by. Post 8vo, cloth, 2s. 6d. ea. Puck on Pegasus. With Jllustrations.

Pegasus Re-Saddled. With Ten full-page Illustrations by G. DU MA URIER.

The Muses of Maylalr : Vers de Sociéte. Selected by H. C. PENNELL.

Phelps (E. Stuart), Works by. Post $8 \mathrm{vo}$, Is. ea. ; cloth, Is. $6 d$. ea. Beyond the Gates. I An Old Mald's Paradise. | Burglars in Paradise.

Jack the Fisherman. Illustrated by C. W. REED. Crown $8 \mathrm{vo}$, Is.; cloth, Is. $6 \mathrm{~d}$.

Phil May's Sketch $=$ Book. Containing 50 full-page Drawings. Imp. 4 to, art canvas, gilt top, Ios. $6 d$.

Pirkis (C. L.), Novels by.

Trooping wlth Crows. Fcap. 8vo, picture cover, is.

Lady Loyelace. J'ost $8 \mathrm{vo}$, illustráted boards, $2 s$.

Planche (J. R.), Works by.

The Pursulyant of Arms. With Six Plates and 209 Inustrations. Crown 8vo, cloth, 75. 6 .

Songs and Poems, 18rg-1879. With lntroduction by Mrs. MACKARNESS. Crown 8vo, cloth, 6s.

Plutarch's Lives of Illustrious Men. With Notes and a Life of Plutarch by JOHN and WM. LANGHORNE, and Portraits. Two Vols., demy 8vo, half-bound sos. $6 d$.

Poe's (Edgar Allan) Choice Works in Prose and Poetry. WVith Intro. duction by CHARLES BAUDELAIRE, Portrait and Facsimiles, Crown 8vo, cloth, 75 . $6 \%$

The Mystery of Marie Roget, \&c. Post 8vo, illustrated boards, \&f. 
Pope's Poetical Works. Post 8vo, cloth limp, $2 s$.

Praed (Mrs. Campbell), Novels by. Post 8vo, illust. bds., 2s. each. The Romance of a Station.

Outlaw and Lawmaker. Crown $8 \mathrm{vo}$, cloth, $35.6 d$; post 8 vo, boards, $2 s$.

Christina Chard. With Frontispiece by W. PAGET. Crown 8vo, cloth, $35.6 d$.

Price (E. C.), Novels by.

Yalentina.
Yrown $8 v 0$, cloth extra, $35,6 d$. each; post
| The Foreigners.

I Mrs. Lancaster's Rival.

Geraid. Post 8vo, illustrated boards, 2s.

Princess Olga.-Radna: A Novel. Crown 8vo, cloth extra, 6s.

\section{Proctor (Richard A., B.A.), Works by.}

Flowers of the Sky With 55 Illustrations. Small crown 8vo, cloth extra, 35. $6 d$.

Easy Star Lessons. With Star Maps for every Night in the Year. Crown $8 v 0$, cloth, 6 .

Familiar Science Studies. Crown $8 v o$, cloth extra, $6 s$.

Saturn and its System. With is Steel Plates. Demy 8vo, cloth extra, ros, 6d.

Mysterles of Tlme and Space. With numerous Illustrations. Crown 8vo, cloth extra, $6 s$.

The Universe of Suns, \&c. With numerous Illustrations. Crown 8vo, cloth extra, 65 .

Wages and Wants of Science Workers. Crown 8 vo, 1s. 6 d.

Pryce (Richard).-Miss Maxwell's Affections. Crown 8vo, cloth, with Frontispiece by HAL LUDLOW, 3s. $6 d$; post 8vo, illustrated boards, $2 s$.

Rambosson (J.).-Popular Astronomy. Translated by C. B. PrTMAN. With Coloured Frontispiece and numerous Illustrations. Crown 8vo, cloth extra, $75.6 d$.

Randolph (Lieut. =Col. George, U.S.A.).-Aunt Abigail Dykes : A Novel. Crown 8 vo, cloth extra, $75.6 d$.

Reade's (Charles) Novels.

Crown 8vo, cloth extra, mostly lllustrated, 35. $6 d$. each; post 8vo, illustrated boards, 2s. each.

Peg Woffington. I Christie Johnstone.

'It is Never Too tate to Mend.'

The Course of True Loye Never Did Run

Smooth.

The Autobiography of a Thief; Jack of

all Trades; and James Lambert.

Loye Me Little, Loye Me Long.

The Double Marrlage.

The Clolster and the Hearth.

Hard Cash

Foui Play, | Put Yourself in His Place. A Terrible Temptation,

A Simpleton. I The Wandering Helr. A Woman-Hater.

Singleheart and Doubleface.

Good Stories of Men and other Animals. The Jilt, and other Stories.

A Perilous Secret. i Readiana.

A New Collected LIBRARY EDITION, complete in Seventeen Volumes, set In new long primer type, printed on laid paper, and elegantly bound in cloth, price $35.6 d$. each, is now in course of publication. The volumes will appear in the following order:-

2. Peg Woffington; and Christie Johnstone.

2. Hard Cash.

3. The Clolster and the Hearth. With a Preface by Sir WAITER BESANT.

4. 'It is Neyer too Late to Mend.' [Dec.

5. The Course of True Love Never Did Run Smooth; and Slagleheart and Doubleface.
[7an. 1806.

6. The Autobiography of a Thief; Jack of all Trades; $A$ Hero and $a$ Mar. tyr; and The W andering Heir. [Feb.
7. Loye Me Little, Love me Long. [Mar. 8. The Double Marrlage. 9. Griffith Gaunt.

10. Foul Play.

11. Put Yourseif in His Place.

12. A Terrible Temptation.

13. A Simpleton.

14. A Woman-Hater. Storles of Men \& other ; and Good 16. A Perilous Secret. 17. Readiana; \& Bible Characterm.[7an.' 97

POPULAR EDITIONS, medium 8vo, $6 d$, each ; cloth, Is, each. 'It Is Nexer Too Late to Mend.'

Christie Johnstone. With Frontispiece. Choicely printed in Elzevir style. Fcap. 8vo, half-Roxb.25.6d. Peg Woffington. Choicely printed in Elzevir style. Fcap. 8vo, half-Koxburghe, $2 s .6 d$.

The Clolster and the Hearth. In FourVols., post 8vo, with an Introduction by Sir WALTER BF. SANT, and a Frontispiece to each Vol, $x_{4}$. the set; and the ILLUSTRATED LIBRARY EDITION, wlth Illustrations on every page, Two Vols., crown 8vo, cloth gilt, 42s, net.

Bible Characters. Fcap. 8vo, leatherette, is.

Selections from the Works of Charles Reade. With an Introduction by Mrs. ALEX. IRE. LAND. Crown 8vo, buckram, with Portrait, 6s.; CHEAP EDITION, post 8vo, cloth limp, $2 s$. Gd.

Riddell (Mrs. J. H.), Novels by.

Weird Stories. Crown $8 \mathrm{vo}$, cloth extra, 3s. $6 d^{\circ}$; post $8 \mathrm{vo}$, illustrated boards, 25. Post 8vo, illustrated boards, 25 . each.

The Uninhabited Iouse.

The Prince of Wales's Garden Party.

The Mystery in Palace Gardens.
Fairy Water.

Her Mother's Darling

The Hun's Curse, I Idle rales. 
Rimmer (Alfred), Works by. Square 8vo, cloth gilt, 7s, 6d. each. Our old Country Towns. With 55 Illustrations by the Author.

Rambles Round Eton and Harrow. With 50 Illustrations by the Author.

A bout England with Dickens. With 58 llistrations by C. A. VANDER HOOF and A. RIMMER,

Rives (Amelie).-Barbara Dering. Crown 8vo, cloth extra, 3s. $6 d$.; post 8vo, illustrated boards, 25 .

Robinson Crusoe. By Daniel Defoe. (Major's Edition.) With 37 Illustrations by GEORGE CRUIKSHANK. Post 8vo, half-bound, $2 s$.

Robinson (F. W.), Novels by.

Yomen are'stranse. Post 8 ro, illustrated boards, 25.

The Hands of Justice. Crown $8 v 0$, cloth extra, $35.6 d$. ; post $8 v 0$, illustrated boards, 25.

The Woman in the Dark. Two Vols, ros, net.

Robinson (Phil), Works by. Crown 8vo, cloth extra, 6s, each.

The Poets' Birds.

The Poots and Nature: Reptlies, Fishes, and Insects.

Rochefoucauld's Maxims and Moral Reflections. With Notes and an Introductory Essay by SAINTE-BEUVE. Post 8vo, cloth limp, 25.

Roll of Battle Abbey, The: A List of the Principal Warriors who came from Normandy with William the Conqueror, 1066. Printed in Gold and Colours, 5 .

Rosengarten (A.).-A Handbook of Architectural Styles. Trans. lated by W. COLLETT-SANDARS. With 630 Illustrations. Crown 8vo, clotb extra, 75.62 .

Rowley (Hon. Hugh), Works by. Post 8vo, cloth, 2s. 6d. each. Puniena: Riddles and Jokes. With numerous Illustrations. More Puniana. Profusely jllustrated.

Runciman (James), Stories by. Post 8vo, bds., 2s. ea.; cl., 2s. 6d. ea. Skippers and Shellbacks. Schools and Scholars.

Grace BaImaign's Swoetheart.

Russell (Dora), Novels by. Crown 8vo, cloth, 3s. $6 d$. each. A Country Sweetheart. 1 The Drift of Fate.

[Shortly.

Russell (W. Clark), Books and Novels by.

Crown $8 v o$, cloth extra, 6 s. each ; post $8 v 0$, illustrated boards, 25 . each ; cloth limp, $25.6 d$. each. Round the Galley-Fire. In the Middle Watch.

A Yoyage to the Cape. A Book for the Hammock. The Mystery of the 'Ocean Star.' The Romance of Jenny Harlowe.

Crown $8 \mathrm{vo}$, cloth extra, 3s. $6 d$. each ; post $8 v 0$, illustrated boards, $2 s$. each; cloth limp, 2s. $6 d$. each.
An Ocean Iragedy.
I My Shipmate Louise. I Alone on a Wide Wlde Sea. Crown 8 vo, cloth, $35.6 d$. each.

Is He the Man?

The Goodship "Mohock."

The Phantom Death, \&c. With Frontispiece. The Convict Ship.

[Shortly.

On the Fo'k'sle Head. Post 8vo, illustrated boards, $2 s$. ; cloth limp, 2s. 6 .

Heart of Oak. Three Vols., crown 8vo, 155 . net.

The Tale of the Ten. Three Vols., crown 8 vo, 15s. net.

[Shortiy.

Saint Aubyn (Alan), Novels by.

Crown $8 v o$, cloth extra, 35.6 . each; post $8 v o$, illustrated boards, $2 s$. each.

A Fellow of Trinity. With a Note by OLIVER WENDELl Holmes and a Frontispiece.
The Junior Dean.
| The Master of St. Benedict's, | To His Own Master.
Fcap. 8vo, cluth boards, $x s .6 d$. each.

The Old Maid's Sweetheart. I Modest Little Sara.

Crown 8vo, cloth extra, $35.6 d$. each.

Orchard Damerel. I In the Face of the World. I Tho Tremlett Diamonds. [Shortly Sala (George A.).-Gaslight and Daylight. Post 8vo, boards, $2 s$.

Sanson.- Seven Generations of Executioners: Memoirs of the Sanson Family (1688 to 1847). Crown 8vo, cloth extra, 35. $6 d$.

Saunders (John), Novels by.

Crown 8vo, cloth extra, 35. 6 d. eacb; post 8vo, illustrated boards, 2s, each.

Guy Waterman.

I The Lion in the Path.

I The Tyo Dreamerg.

Round to the Wheel, Crown 8 vo, clotb extra, $3^{s,} 6 d$. 
Saunders (Katharine), Novels by.

Crown $8 v o$, cloth extra, $35.6 d$. each ; post $8 v 0$, illustrated boards, 2s, each

Margaret and Elizabeth,

Heart Salyage.

The High Mills.

Sebastian,

Joan Merryweather. Post $8 v o$, illustrated boards, zs.

Gideon's Rock. Crown 8vo, cloth extra, $3 s, 6 . t$.

Scotland Yard, Past and Present: Experiences of Thirty-seven Years. By Ex.Chief-Inspector CAVANAGk. Post 8vo, illustrated boards, 2s.; cloth, 25. 6d.

Secret Out, The : One Thousand Tricks with Cards; with Entertaining Experiments in Drawing-room or 'White' Magic. By W. H. CREMER. With 300 llustrations. Crown 8vo, cloth extra, $45.6 d_{*}$.

Seguin (L. G.), Works by.

The Country of the Passion Play (Oberammergan) and the Highlancls of Bavaria. With Map and 37 Illustrations. Crown $8 v 0$, cloth extra, $3^{5}$. $6 \alpha^{2}$.

Walks in Aiglers. With Two Maps and $x 6$ Illustrations. Crown $8 v o$, cloth extra, $6 s$.

Senior (Wm.).-By Stream and Sea. Post 8vo, cloth, 2s. $6 d$.

Sergeant (Adeline).-Dr. Endicott's Experiment. Crown 8vo, buckram, 35. 6d.

Shakespeare for Children: Lamb's Tales from Shakespeare. Witl Illustrations, coloured and plain, by J. MOYR SMITH. Crown 4to, cloth gilt, $35.6 d$.

Sharp (William).-Children of To-morrow. Crown, 8vo, cloth, 6s.

Shelley's (Percy Bysshe) Complete Works in Verse and Prose. Edited, Prefaced, and Annotated by R. HERNE SHEPHERD. Five Vols., crown 8vo, cloth, 35. $6 d$, each.

Poetical Works, in Three Vols, :

Vol. I. Introduction by the Editor: Posthumous Fragments of Margaret Nicholson; Shelley's Corre spondence with Stockdale; The Wandering Jew; Queen Mab, with the Notes; Alastor, and other Poems; Rosalind and Helen ; Prometheus Unbound; Adonais, \&

11. Laon and Cythna: The Cenc;; Julian and Maddalo; Swellfoot the Tyrant; The Witch of Atlas; Epipsychidion: Hellas.

" 111. Posthumous Poems; The Masque of Anarchy; and other Pieces.

Prose Works, in Two Vols.

Vol. I. The Two Romances of Zastrozzi and St. Irvyne: the Dublin and Marlow Pamphlets; A Refur tation of Deism; Letters to Leigh Hunt, and some Minor Writings and Fragments.

" 11. The Essays: Letters from Abroad: Translations and Fragments, edited by Mrs. SHELLEY. With a Biography of Shelley, and an Index of the Prose Works.

*** Also a few copies of a LARGE-PAPER EDition, 5 vols., cloth, £2 I2s. $6 d$.

Sherard (R. H.).-Rogues: A Novel. Crown 8vo, Is. ; cloth, Is. 6d.

Sheridan (General P. H.), Personal Memoirs of. With Portraits, Maps, and Facsimiles. Two Vols, demy 8 vo, cloth, 245.

Sheridan's (Richard Brinsley) Complete Works, with Life and Anecdotes. Including his Dramatic Writings, his Works in Prose and Poetry, Translations, Speeches, and Jokes. With ro Illust rations. Crown 8vo, half-bound, 7s, $6 d$.

The Rlyals, The School for Scandal, and other Plays. Post 8vo, half-bound, 25.

BhorIdan'e Comedles: The Rixals and The School for Scandal. Edited, with an Introduction and Notes to each Play, and a Biographical Sketch, by BRANDER MATTHEWS. With Illustrations. Demy 8vo, half-parchment, i2s. $6 d$.

Sidney's (Sir Philip) Complete Poetical Works, including all those in 'Arcadia.' With Portrait, Memorial-Introduction, Notes, \&c., by the Rev. A. B. GROSART D.D. Three Vols., crown 8 vo, cloth boards, 18 .

Sims (George R.), Works by.

Post $8 v 0$, illustrated boards, 2s, each; cloth limp, 25. 6d, each.

Rogues and Yasabonds,
The Ring o' Bells.
Mary Jane's Memoirs,
Mary Jane Married.
Tinkletop's Crime.
Zeph: A Circus Story, \&c.

Tales of To-day.

Dramas of Life. With 60 Illustrations.

Memoire of a Landiady.

Ecenes from the Show.

The Ten Commandments: Stories [Shortly.

Crown 8ro, picture cover, is. each; cloth, $1 s .6 d$. each.

How the Poor Live; and Horrlble London. The Dagonet Reciter and Reader : Being Readings and Recitations in Prose and Verse,

The Case of Gaorge Candlemas. i Dagonet Ditiles. (From The Referee.)

Dagenet Abroad. Crown 8vo, cloth, $35.6 \%$ 
Signboards : Their History, including Anecdotes of Famous Taverns and Remarkable Characters. By JACOB LARWOOD and JOHN CAMDEN HOTTEN. With Coloured Frontis piece and 94 Illustrations, Crown 8vo, cloth extra, $75.6 d$.

Sister Dora: A Biography. By Margaret Lonsdale. With Four Illustrations. Demy $8 \mathrm{vo}$, picture cover, $4 d$; cloth, $6 d$.

Sketchley (Arthur).-A Match in the Dark. Post 8vo, boards, 2s

Slang Dictionary (The): Etymological, Historical, and Anecdotal. Crown 8vo, cloth extra, 6s, 6 \%.

Smart (Hawley).-Without Love or Licence: A Novel. Crown $8 v 0$, cloth extra, 3 s. 6 d.; post $8 \mathrm{vo}$, illustrated boards, 2 .

Smith (J. Moyr), Works by.

The Prince of Ârgolis. With $x 30$ Illustrations. Post $8 v 0$, cloth extra, $35.6 d$.

The Woolng of the Water Witch. With numerous Illustrations, Post $8 \mathrm{vo}$, cloth, $6 \mathrm{s.}$

Society in London. Crown 8vo, Is. ; cloth, Is. 6d.

Society in Paris: The Upper Ten Thousand. A Series of Letters from Count PAUL VASILI to a Young French Diplomat. Crown 8vo, cloth, 6 s.

Somerset (Lord Henry).-Songs of Adieu. Small 4 to, Jap. vel.,6s.

Spalding (T. A., LL.B.) - Elizabethan Demonology: An Essay on the Belief in the Existence of Devils. Crown 8 vo, cloth extra, 5 s.

Speight (T. W.), Novels by.

Post 8 vo, illustrated boards, 2s, each.

The Mysterles of Heron Dyke.

By Devious Ways, \&c.

Hood winked; \& Sandycroft Mystery.

Back to Lite.

The Golden Hoop.

The Loudwatex Tragedy.

Burgo's Romance.

Quitance in Full.

Post $8 \mathrm{vo}$, cloth limp, xs. 6 d. each

A Barren Title. | Wite or No Wife?

The Sandycroft Mystery. Crown $8 v o$, picture cover, $x$ s.

Crown $8 v 0$, cloth extra, $35,6 \%$, each.

A Secret of the Sea.

The Grey Monk.

Shortly.

Spenser for Children. By M. H. TowRY. With Coloured Illustrations by WALTER J. MORGAN. Crown 4to, cloth extra, 35. $6 d$.

Starry Heavens (The): A Poetical Birthday Book. Royal I6mo, cloth extra, 2s. $6 d$.

Stedman (E. C.), Works by. Crown 8vo, cloth extra, 9s. each. Yictorian Poets. | The Poets of America.

Sterndale (R. Armitage).-The Afghan Knife: A Novel. Crown $8 v o$, cloth extra, $3^{s}$. $6 d$.; post $8 \mathrm{vo}$, illustrated boards, $2 s$.

Stevenson (R. Louis), Works by. Post 8vo, cloth limp, 2s. 6d, ea. Trayel: with a Donkey. With a Frontispiece by WALTRR CRane. An Inland Yoyage. With a Frontispiece by WALTER CRANE.

Crown 8vo, buckram, gilt top, 6 s. each.

Familiar Studies of Men and Books.

The Sllverado Squatters. With Frontispiece by J. D. STRONG.

The Merry Men. I Underyoods: Poems.

Memorles and Portraits.

Yirginfbus Puerisque, and other Papers. I Ballads.

Across the Plains, with other Memories and Essays.

I Pxince Otto.

New Arabian Nights. Crown 8 vo, buckram, gilt top. $6 s$.; post 8 vo, illustrated boards, $2 s$.

The Sufcide club; and The Rajah's Diamond. (From NEW ARABIAN NIGHTS.) With Eight Illustrations by W. J. HENNESSY. Crown $8 v 0$, cloth, 5.

Father Damien: An Open Letter to the Rev. Dr. Hyde. Cr. 8vo, liand-made and brown paper, $x$.

The Edinburgh Edition of the Works of Robert Louis Stevenson. Twenty Vols. demy 8vo. This Edition (which is limited to $\mathrm{r}, 000$ copies) is sold only in Sets, the price of which may be learned from the Bocksellers. The Vols are appearing at the rate of one a month, beginning Nov. 1894.

Gelx of Hermiston, (R. L. STEVENSON'S LAST WORK.) Large crown 8vo, 6s. [Shortly. 
Stoddard (C. Warren).--Summer Cruising in the South Seas. IHustrated by WALLIS MACKAY. Crown $8 \mathrm{vo}$, cloth extra, $35.6 d$.

Stories from Foreign Novelists. With Notices by HELEN and ALICE ZIMTMERN. Crown 8vo, cloth extra, 35. 6d.; post 8vo, illustrated boards, 25 .

Strange Manuscript (A) Found in a Copper Cylinder. Crown 8 vo, cloth extra, with 19 lllustrations by GiLBERT GAUL, 5s. ; post 8vo, illustrated boards, 25 .

Strange Secrets. Told by Percy Fitzgerald, Conan DOyle, FlorENCE MARRYAT, \&C. Post 8vo, illustrated boards, 2.5 .

Strutt (Joseph). - The Sports and Pastimes of the People of England ; including the Rural and Domestic Recreations, May Games, Mummeries, Shows, \&c., from the Earliest Period to the Present Time. Edited by WiLliam HONE. With I $_{0}$ Illustrations. Crown $8 v 0$, cloth extra, $75,6 d$.

Swift's (Dean) Choice Works, in Prose and Verse. With Memoir, Portrait, and Facsimiles of the Maps in 'Gulliver's Travels.' Crown 8vo, cloth, 7s, $6 d$. Gulllyer's Trayels, and A Tale of a Tub. Post 8 vo, half-bound, 25 .

Jonathan Swift: A Study. By J. CHURTON Collins. Crown $8 v 0$, cloth extra, 85.

Swinburne (Algernon C.), Works by.

Belectlons from the Poetical Works of A. C. Swinburne. Fcap. 8 vo, 65 .

A talanta in Calydon. Crown $8 \mathrm{vo}, 6 s$.

Chastelard: A Tragedy. Crown 8vo, 75 .

Poems and Ballads. FIRST SERIES. Crown $8 \mathrm{vo}$, or fcap. 8vo, gs.

Poems and Ballads, SECOND SERtes. Crown $8 \mathrm{vo}, 95$.

Poems \& Baliads, THIRD SERIES. Cr.8vo, 7s.

Sonfs before Sunrise. Crown 8 vo, ros. $6 d$.

Bothwell: A Tragedy. Crown 8vo, r2s. 6 .

Songs of Two Nations. Crown 8 vo, $6 s$.

George Chapman. (See Vol. 11. of G. CHAP.

MAN's Works.) Crown $8 \mathrm{vo}, 6 s$.

Essays and Studles. Crown 8vo, r2s.

Erechtheus: A Tragedy. Crown 8vo, $6 s$.

A Note on Charlotte Bronte. Cr. 8vo, $6 s$. A Study of Shakespeare. Crown $8 v_{0}, 8 s$. Songs of the Springtides. Crawn $8 \mathrm{vo}, 6 \mathrm{~s}$. Studles in Sons. Crown $8 \mathrm{vo}, 75$.

Mary Stuart: A Tragedy. Crown 8 vo, 8 s. Tristram of Lyonesse. Crown $8 v 0$, 9 s.

A Century of Roundeis. Small 4 to, 85. A Midsummer Hollday. Crown $8 v_{0}, 75$. Marino Faliero: A Tragedy. Crown 8vo, 6 s. A Study of Yictor Hugo. Crown $8 v 0,6$ s. Miscellunles. Crown $8 \mathrm{vo}$, I2s.

Locrine: A Tragedy. Crown $8 v 0,6 s$.

A Study of Ben Jonson. Crown $8 \% 0,75$.

The Sisters: A Tragedy. Crown 8vo, 6s.

Astrophe1, \&ic. Crown 8vo, 7s.

Studies in Prose and Poetry. Cr.8vo, os.

Syntax's (Dr.) Three Tours : In Search of the Picturesque, in Search of Consolation, and in Search of a Wife. With ROWLANDSON'S Coloured Ihustrations, and Life of the Author by J. C. HOTTEN. Crown 8vo, cloth extra, 75. $6 d$.

Taine's History of English Literature. Translated by HENRY VAN LAUN. Four Vols., small demy 8vo, cloth boards, 30s,-PopUla EDITION, Two Vols., large crown 8 vo, cloth extra, 15 s.

Taylor (Bayard). - Diversions of the Eclio Club: Burlesques of Modern Writers. Post $8 v 0$, cloth limp, 2s.

Taylor (Dr. J. E., F.L.S.), Works by. Crown 8vo, cloth, 5s. each. The Sagacity and Morality of Plants: $\Lambda$ Sketch of the Life and Conduct of the Vegetable Kingdom. With a Coloured Frontispiece and roo lllustrations,

Our Common Britlsh Fossils, and Where to Find Them. With 33 Illustrations.

The Playtime Naturalist. With 366 lllustrations.

Taylor (Tom). - Historical Dramas. Containing 'Clancarty, 'Jeanne Darc," "Twixt Axe and Crown," 'The Fool's Revenge,' 'Arkwright's Wife,' 'Anne Boleyn, - Plot and Passion." Crown 8vo, cloth extra, 7s. $6 d^{\circ}$

$*_{*}^{*}$ The Plays may also be had separately, at xs. each.

Tennyson (Lord) : A Biographical Sketch, By H. J. Jennings. Post 8 vo, portrait cover, $x s_{0} ;$ cloth, $x s .6$.

Thackerayana: Notes and Anecdotes. With Coloured Frontispiece and Hundreds of Sketches by WILLIAM MAKEPEACE THACKERAY. Crown 8vo, cloth extra, 7s. 6d.

Thames, A New Pictorial History of the. By A. S. Krausse. With 340 Illustrations. Post $8 \mathrm{vo}$, rs, ; cloth, is. 6 \%.

Thiers (Adolphe). - History of the Consulate and Empire of France under Napoleon. Translated by D. FORBES CAMPBEI,L and JOHN STEBBING. With 36 Steel Plates. 12 Yols, demy $8 \mathrm{yo}$, cloth extra, I2s. each, 
Thomas (Bertha), Novels by. Cr. 8vo, cl., 3s. 6d. ea.; post 8vo, 2s. ea. The Yiolin-Player.

I Proud Maisie.

Cresslda. Post 8 ro, illustrated boards, $2 s$.

Thomson's Seasons, and The Castle of Indolence. With Intro. duction by ALLAN CUNNINGHAM, and 48 lilustrations. Post 8vo, half-bound, $2 s$.

Thornbury (Walter), Books by.

The Life and Correspondence of J. III. W. Turner. With Illustrations in Colours. Crown $8 \mathrm{vo}$, cloth oxtra, $7 s, 6 d$.

Oid stories Re-told. $\quad$ Tales for the Marines.

Post 8ro, illustrated boards, 2s, each.

Timbs (John), Works by. Crown 8vo, cloth extra, 7s. 6d, each.

The History of Clubs and Club Cife in London: Anecdotes of its Famous Coffee-houscs, Hostclries, and Taverns. With 42 Illustrations.

English Eccentrics and Eccentricitles: Stories of Delusions, Impostures, Sporting Scenes, Iiccentric Artists, Theatrical Folk, \&c. With 48 lllustrations.

Trollope (Anthony), Novels by.

Crown $8 \mathrm{vo}$, cloth extra, 35. 6d. each; post $8 \mathrm{vo}$, illustrated boards, 25 , each.

The Way We Lre Now.

Frau Frohmann.

Kept In the Dark.

The Golden Lion of Granpere.
Mr. Scarborough's Family.

The Land-Leaguers.

Post $8 \mathrm{vo}$, illustrated boards, 2s, each.

The Amerlcan Senator. John Caldigato. | Marion Fay.

Trollope (Frances E.), Novels by.

Crown 8vo, cloth extra, 3.5. 6 , each; post 8 vo, illustrated boards, 25 , cach.

Like ShIps Upon the Sea. I Mabel's Progress.

I Anne Furness.

Trollope (T. A.).-Diamond Cut Diamond. Post 8 vo, illust. bds., $2 s$.

Trowbridge (J. T.).-Farnell's Folly. Post $8 v 0$, illust. boards, $2 s$.

Tytler (C. C. Fraser $=$ ).-Mistress Judith : A Novel. Crown 8vo, cloth extra, 3s. $6 \alpha^{\prime}$; ; post $8 v 0$, illustrated boards, 25 .

Tytler (Sarah), Novels by.

Crown 8vo, cloth extra, 3s. $6 d$. each; post $8 v o$, illustrated boards, 25 . each.

Lady Boll.

Post $8 \mathrm{vo}$, lllustrated boards, 25 . each.

What Bhe Came Through.

Cltoyenne Jacqueline.

The Bride's Pass.

Saint II ungo's City.

The Huguenot Family.

Noblesse Oblige.

Beauty and the Beast.

Disappeared.

The Macdonald Lass. With Frontisplece. Crown 8 vo, cloth, 3 s. $6 d$.

Upward (Allen), Novels by.

The Queen Agalnst O wen. Crown 8vo, cloth, with Frontispiece, 3s. 6d.; post 8vo, boards, 2s.

The Prince of Balkistan. Crown 8vo, clath cxtra, $3 s .6 d$.

Vashti and Esther. By the Writer of 'Belle's' Letters in The World. Crown 8vo, cloth extra, $35.6 d$.

Villari (Linda).-A Double Bond: A Story. Fcap. 8vo, is.

, Vizetelly (Ernest A.).-The Scorpion : A Romance of Spain. With a Frontispiece. Crown $8 v o$, cloth extra, $3^{s}, 6 d$.

Walton and Cotton's Complete Angler; or, The Contemplative Man's Recreation, by IZAAK WALTON; and Instructions How to Ancle, for aTrout or Grayling in a clear Stream, by CHARLES COTTON. With Memoirs and Notes by Sir HARRIS NICHOLAS, and 6x lllustrations. Crown 8vo, cloth antique, $7 s .6 d$.

Walt Whitman, Poems by. Edited, with Introduction, by WilliaM M. Rossetri. With Portrait. Crown $8 v^{\circ}$, hand-made paper and buckram, $6 s$.

Ward (Herbert), Books by.

Five Years with the Congo Cannibals. With 92 Illustrations. Royal 8vo, cloth, I4s.

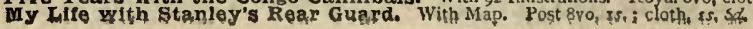




\section{Walford (Edward, M.A.), Works by.}

Walford's County Famlles of the United Kingdom (1896). Containing the Descent. Birth, Marriage, Education, \&c., of 12,000 Hcads of Fanilies, their Heirs, Offices, Addresses, Clubs, Sic. Royal 8vo, cloth gilt, 50 .

Yalford's Shilling Peerage (1898). Containing a List of the Ilouse of Lords, Scotch and Irish Pecrs, \&c. $32 \mathrm{mo}$, cloth, Is.

Walford's Shij]ing Baronetage (1896). Containing a List of the Baroncts of the United Kingdom, 13iographical Notices, Aduresses, \&c. $32 \mathrm{mo}$, cloth, is.

Walford's Shilling Knlghtage (1896). Containing a List of the Knights of the United Kingdom, Biographical Notices, Addresses, \&c. 32mo, cloth, Is.

Walford's Shillng House of Commons (1896). Containing a List of all the Members of the New Parliament, their Addresses, Clubs, \&c. 32mo, cloth, is.

Walford's Complete Peerage, Baronetage, Knightage, and Iouse of Commons (1996). Royal $32 \mathrm{mo}$, cloth, gilt edges, $5^{5}$.

Tales of our Great Familles. Crown 8vo, cloth extra, $35.6 d$.

Warner (Charles Dudiey).-A Roundabout Journey. Crown 8vo, cloth extra, $6 s$.

Warrant to Execute Charles I. A Facsimile, with the 59 Signatures and Seals. Pristed on paper 22 in. by 14 in. $2 s$.

Warrant to Execute Ihary Queen of Scots. A. Facsimile, Including Quecn Elizabeth's Slgna. ture and the Great Seal. $2 s$.

Washington's (George) Rules of Civility Traced to their Sources and Restored by MONCURE D. CONWAY. Fcap. 8vo, Japaliese vellum, 2s, 6 d.

Wassermann (Lillias), Novels by.

The Daffodils. Crowa 8vo, is. ; cloth, Is. $6 d$.

The Marquis of Carabas. By Aaron Watson and Lillias WasserntaxN. Post 8ro, illustrated boards, $2 s$.

Weather, How to Foretell the, with the Pocket Spectroscope. By F. W. CORY. With Ten Illustratlons. Crown 8vo, is.; cloth, is. 6 d.

Webber (Byron).-Fun, Frolic, and Fancy. With 43 Illustrations by PHIT, MAY and CHARLES MAY, Fcap. 4to, cloth, 55 .

Westall (William), Novels by.

Trust-Money. Post $8 v 0$, illustrated boards, 2s.; cloth, 2s, $6 d$.

Sons of Bellal. Two Vols., crown 8 vo, ios. net.

Whist, How to Play Solo. By Abraham S. Wilks and Charles F. PARDON. Post 8 vo, cloth limp, 2s.

White (Gilbert). - The Natural History of Selborne. Post 8vo, printed on laid paper and half-bound, $2 s$.

Williams (W. Mattieu, F.R.A.S.), Works by. Sclence In Short Chapters. Crown 8vo, cloth extra, 7s, $6 d$.

A Simple Treatise on Heat. With Illustrations. Crown 8vo, cloth, 2s. $6 d$.

The Chemlstry of Cookery. Crown 8 vo, cloth extra, 6 s.

The Chemistry of Iron and steel Making. Crown $8 v 0$, cloth extra, 9s.

A Yindication of Phrenology. With Portrait and 43 Illusts. Deiny 8 vo, cloth extra, I2s. 66 .

Williamson (Mrs. F. H.).-A Child Widow. Post 8vo, bds., $2 s$.

Wilson (Dr. Andrew, F.R.S.E.), Works by.

Chapterg on Exolution. With 259 Illistrations. Crown 8vo, cloth extra, 75. 6d.

Leaves from a Naturailst's Note-Book. Post 8vo, cloth limp, $2 s .6 d$.

Lelsure-Time Studles. With Illustrations. Crown $8 \mathrm{vo}$, cloth extra, 6 s.

Studles In Life and Sense. With numerous Illustrations. Cruwn $8 v 0$, cloth extra, $6 \mathrm{~s}$.

Common Accldents: How to Treat Them. With Jlustrations. Crown 8vo, $15 . ;$; cloth, 15.60 .

Glimpses of Nature. Witl 35 Illustrations, Crown 8vo, clotil extra, $35.6 d$.

Winter (J. S.), Stories by. Post 8vo, illustrated boards, 2s. each ; cloth limp, 2s. 6d, each. Cayalry Life.

| Regimental Legends.

A Soldlex's Chlidren. With 34 Illustrations by E. G. THOMSON and E. STUART IMARDY. Crown $8 v 0$, cloth extra, $35.6:$.

Wissmann (Hermann von). - My Second Journey through 
Wood (H. F.), Detective Stories by. Post 8vo, boards, 2s, each. The Passenger from Scotland Yard. I The Englishman of the Rue Caln.

Wood (Lady).--Sabina: A Novel. Post 8vo, illustrated boards, $2 s$.

Woolley (Celia Parker).-Rachel Armstrong; or, Love and Theology. Post 8vo, illustrated boards, 2s. ; cloth, 2s. $6 d$.

Wright (Thomas), Works by. Crown 8vo, cloth extra, 7s. 6d. each. The Caricature History of the Georges. With 400 Caricatures, Squibs, \&c.

History of Caricature and of the Grotesque in Art, Literature, Sculpture, anc Painting. lllustrated by F. W. FAIKHOLT, F.S.A.

Wynman (Margaret).-My Flirtations. With 13 Illustrations by J. BERNARD PARTRIDGE, Post 8vo, cloth, 3s, $6 d$.

Yates (Edmund), Novels by. Post $8 \mathrm{vo}$, illustrated boards, 2s. each. Land at Last. I The Forlorn Hope. I Castaway.

Zangwill (I.). - Ghetto Tragedies. With Three Illustrations by A. S. BOYD. Fcap. 8vo, picture cover, xs. net.

Zola (Emile), Novels by. Crown 8vo, cloth extra, 3s. 6d, each.

The Fat and the Thin. Translated by ERNEST A. VIZBTELLY.

Money. Translated by ERNEST A. VIZETELLY.

The Downiall. Translated by E. A. VIZE'TELLY.

The Dream. Translated by ELIZA CHASE. With Eight Illustrations by JEANNIOT.

Doctor Pascal. Translated by E. A. VIZETELLY. With Portrait of the Author.

Courdes. Translated by ERNEST A. VIZETELLY.

Rome. Translated by ERNEST A, VIZETELLY.

[Shortly.

\section{SOME BOOKS CLASSIFIED IN SERIES. \\ ** For fuller cataloguing, see alphabetical arrangement, $p p$. $x-26$.}

The Mayfair Library. Post 8vo, cloth limp, 2s. $6 d$. per Volume.

A Journey Round My Room. By X. DE MAISTRE.

Translated by Sir HENKY ATTWELL.

Quips and Qutddtiles. By W. D. ADAMS.

Tho Agony Column of "The Times.

Melancholy Anatomised: Abridgment of BURTON.

Poetical Ingenuities. By W. T. DOBSON.

The Cupboard Papers. By FIN-BEC.

W. S. Gilbert's Plays. Three Series.

Songs of Irish Wit and Humour.

Anlmals and their Masters. 13y Sir A. HELPS.

Soclal Pressure. By Sir A. HELPS.

Curiosities of Criticism. By H. J. JENNINGS.

The Autocrat of the Breakfast.Table. By OLIVBR WENDELL HOL,MES.

Pencil and Palette. By R, KEMPT.

Itttle Essay: : from LAMB'S LETTERS.

Forensic Anecdotes. By JACOB LARWOOD,
Theatrical Anecdotes. By JACOB LARWoOD. Jeux d'Esprit. Edited by HENRY S. LEIGH. Witch Stories. By E. LYNN LINTON. Ourselves. Ly E. LYNN LINTON.

Pastimes and Players. By R. MACGREGriR. New Paul and Virginia. By W. 1H. MALLOCK. The New Republic. By W, H, MALLOCK. Puck on Pegasns. By H. C. PenNell. Pegasus Re-saddled. By H. C. PENNRLL. Munes of Mayfair. Edited by H. C. PENNELL. Thoresu: His Life and Aims. By If. A. YAGB. Punlana. By Hon. HUGH ROWLeY.

More Punlana, By Hon. HUGH ROWLBY. The Phllosophy of Handwriting.

By Stream and Sea. By WILliAM SENIOR.

Leaves from a Naturalist' Note-Book. Dy Dr. ANDREW WILSON.

The Golden Library. Post $8 \mathrm{vo}$, cloth limp, 2s. per Volume.

Diveralons of the Echo Club. BAYARD TAYLOR. Song for Saflors. By W. C. BENNETT.

Lives of the Necromancers. By W. GODWIN.

The Poetical Works of Alexander Pope.

Scenes of Country Life. By EDWAKD JESSE.

Tale for a Chimney Corner. By LEIGH HUNT.
The Autocrat of the Breakfast Table. Dy OLJVER WENDELL HOLMES.

La Mort d'Arthur: Selections from MALLORY. Provincial Letter of Blaise Pascal.

Maxims and ReflectIons of Rochefoucauld.

\section{The Wanderer's Library.}

Wanderings in Patagonia. By JuLIUS BEER. воHM. Illustrated.

Merrie England in the Olden Time. By G. Daniel. Illustrated by ROBERT CRUIKSHANK.

circui Iffe. By THOMAS FROST.

Itves of the Conjurers. By THOMAS Frost.

The Old Showmen and the old London Eairs. By THOMAS FROST.

Iow-Ilfe Deeps. By JAMES GREENWOOD.

The WIds of London. By JAMES GRELNWOOD.
Crown 8vo, cloth extra, $35.6 d$, each.

Tunis. By Chev. HESSE-WARTEGG. 22 lllusts. Life and Adventures of a Cheap Jack.

World Behind the Scenes. By 1. FITZGERALD. Tavern Anecdotes and Saylngs.

The Genial Showman. By E, P. IIINGSTON.

Story of Iondon Parks. By JACOB L_ARWOOD.

London Characters. By HENRY MAYHEW.

Seven Generations of Execntioners,

Summer Cruising in the South Seas. By $C$. WARREN STODDARD. Illustrated. 
BoOKS IN SER1ES-continued.

Handy Novels. Fcap, 8vo, cloth boards, Is. $6 d$, each.

The Old Mald's Sweetheart. By A. ST. AUBYN. Modest Little Bara. By ALAN ST. AUBYN.

Beven Sleepers of Ephesus. M. E. COLERIDGe. A Lost Soul. By W. L. ALDEN. Dr. Palliser's Patient. By GRANT ALLFN. Monte Carlo Storles. By JOAN BARRETT.

My Library. Printed on laid paper, post 8vo, half-Roxburghe, 2s. $6 d$. each. cltation and Examination of William Shakspeare. Chrlstle Johnatone. By CHARLES READE. By W. S. LANDOR.

The Journal of Maurice de Gnerin.

Peg Wofington. By CHARLES READF.

The Dramatic Eseays of Charles Lamb.

The Pocket Library. Post 8vo, printed on laid paper and hf.-bd., 2s. each.

The Esagys of Ella. By CHARLES LAMB. Robinson Grusoe. Illustrated by G. CRUIKSHANK, Whims and Odditles. By THOMIAS HOOD. The Barber's Chair, By DOUGLAS JERROLD. Oastronomy. By BRILLAT-SAVARIN.

The Eplcurean. \&c. By THOMAS MOORE. Leigh Hunt's Essays. Edited by E, OLLIER.
Whlte' Natnral Hlstory of Selborne.

Gulliver's Travels, \&c. By Dean SWIFT.

Plays by RICHARD BRINSLEY SHERIDAN.

Anecdotes of the Clergy. By JACOB LARwOOD. Thomson's Seasons. Illustrated.

A u tocrat of the Breakfast-Table and The Profestor at the Breakfast-Table. By O. W. HOL,MES.

\section{THE PICCADILLY NOVELS.}

Library Editions of Novels, many lllustrated, crown 8vo, cloth extra, $35.6 d$. each.

Green as Grass. By F. M. ALLEN. By GRANT ALLEN.

Phillatla.

Strange Storles.

Eabylon.

For Maimle's Saze.

In all Shades.

The Beckoning Hand.

The Devil's Die.

This Mortal Coll.

The Tents of Shem.

The Great Taboo.

Dnmaresq' Daughter. Duchess of Powysland. Blood Royal.

Ivan Greet's Masterplece.

The Scallywag. At Market Vaino. Under Sealed Orders.

BY MARY ANDERSON.

Othello' Occupation.

By EDWIN L. ARNOLD.

Phra the Phoenician.

The Constsble of St. Nicholas.

By Rev. S. BARING=GOULD.

Red spider. | Eve.

BY ROBERT BARR.

In a steamer Chalr. IFrom Whose Botrue.

By FRANK BARRETT.

The Woman of the Iron Bracelets.

IBy 'BELLE.'

Vashti and Eather.

By Sir W. BESANT and J. RICE.

Ready.MoneyMortiboy. By Celia's Arbour.

My Little Girl.

With Harp and Crown.

This Son of Vulcan.

Chaplain of the Fleet. The Seamy side.

The Case of Mr. Lucraft.

The Golden Eutterily. In Trafalgar Bay.

The Monks of Thelems. The Ten Year: Tenant.

By Sir WALTER BESANT.

Ail Sorts and Condi. For Faith and Freedom. tions of Men.

The Captains' Room.

Ail in a Garden Fair.

Dorothy Forater.

Uncle Jack.

The World Went Very

Well Then.

Children of Gibeon.

Herr Paulus.

By ROBERT

shadow of the Sword.

A Chdid of Nature.

God and the Man.

Martyrdom of Madeline

Love Me for Ever.

Annan Water.

Eoxglove Manor.

To Call Her Mine.

The Bell of St. Paul's.

The Holy Rose.

Armorel of Lyonesse.

S. Katherine's by Tower

Verbena Camellia Stephanotis.

The Ivory Gate.

The Rebel Queen.

BUCHANAN.

The New Abelard. Matt. I Rachel Dene. Master of the Mine.

The Heir of Linne.

Woman and the Man.

Red and White Heather.

ROB. BUCHANAN \& HY. MURRAY. The Charlatan.

BY J. MITCHELL CHAPPLE.

Tho Minor Chord.
By HALL CAINE.

The Shadow of a Crime. The Deemater.

$\Delta$ Son of Hagar.

BY MACLAREN COBBAN.

The Red Sultan. |The Burden of Isabel.

By MORT. \& FRANCES COLLINS.

Transmigration. Blacksmith \& Scholar. night.

The Village comedy. You Play me False. BY WILKIE COLLINS.

Armadale.

After Dark.

The Two Deatinies.

- The Law and the Lady.

The Haunted Hotel.

Basil.

Hide and Seek.

The Dead secret.

Queen of Hearts.

My Miscellanies.

The Woman In White:

The Moonatone.

Man and Wife.

Poor Miss Finch.

Miss or Mrs. ?

The New Magdalen.

The Failen Leaves.

Jezebel's Danghter.

The Biack Robe.

Heart and sclence.

'I Say No.'

Ilttie Novels.

The Evil Genins.

The Legacy of Caln.

A Rogue's Iffe.

Blind Love.

By DUTTON COOK.

Panl Foster's Daughter. By E. H. COOPER.

Geoflory Hamition.

BY V. CECIL . COTES.

Two Glrls on a Barge.

By C. EGBERT CRADDOCK,

His Vantshed Star.

By H. N. CRELLIN.

Romances of the Old Seraglio.

By MATT CRIM.

The Adrentures of a Falr Rebel.

By S. R. CROCKETT and otherE.

Tales of Onr Coast. By B. M. CROKER.

Diana Barrington.

Proper Pride.

A Family Ilkenes.

Pretty Miss Nevllle.

A Bird of Passage. 'To Let.' Viliage Tales \& Jnnglo

Trazedies. The Real Lady Hlida.

Hearts of Gold.

BY ALPHONSE DAUDET.

The Evangellst; or, Yort Salvation.

By H. COLEMAN DAVIDSON. Mr. Sadler's Daughters.

By ERASMUS DAWSON.

The Founcain of Youth.

BY JAMES DE MILLE.

$\Delta$ Castlo in spain. 
The Prccadilly $(3 / 6)$ Novels-continued. By. J. LEITH DERWENT.

Our Lady of Tears. I Circe's Lovers. By DICK DONOVAN.
Iracked to Doom.

By A. CONAN DOYLE.

The Firm of Girdlestone.

By S. JEANNETTE DUNCAN.

A Daughter of To-day. I Vernon's Aunt.

By G. MANVILLE FENN.

The New Mistress.

Witness to the Doed. The White Virgin.

Fatal Zero.

By PERCY FITZGERALD.

By R. E. FRANCILLON.

One by One.

A Dog and his shadow. Ropes of Sand.

A Real Queen.

Prefaced by SIr BARTLE FRERE.

randurang Hari.

The Capel Girls.

BY EDWARD GARRETT.

The Red shirts.

$$
\text { By PAUL GaUlo't. }
$$

BY CHARLES GIBBON.

\begin{tabular}{l|l} 
Robin Gray. & The Golden Shaft. \\
Loving a Dream.
\end{tabular}

By E. GLANVILLE.

The Lost Heuress.
A Fair Colonist.

By E. J. GOODMAN.

The Fate of Herbert Wayne.

By CECIL GRIFFITH.

Corinthia Marazion.

BY SYDNEY GRUNDY.

The Days of his Vanity.

By THOMAS HARDY.

Under the Greenwood Tree.

BY BRET HAR'TE.

A Waif of the Plains. Susy.

A Ward of the Golden Sally Dows.

Gate.

A Sappho of Green

spring.

A Protégée of Jack Aumlin's. Bell-Ringer of Angel's.

Col. Starbottle's Client. Clarence. BY JULIAN HAW'THORNE.

Garth.

Ellice onentin.

Sebastian 8 trome.

Dust.

Fortune's Fool.

Beatrix Randolph. David Poindexter's Dis. appearance. The Spectre of the

Ivan de Biron.

By SIr A. HELPS.

Agatha Page.

By 1. HENDERSON.

By G. A. HENTY.

Rujnb the Juggler. i Dorothy's Double. By JOHN HILL.

The Common Ancestor.

By Mrs. HUNGERFORD.

3.ady Verner's Fight. | The Red-House Mystery.

The Three Graces.

By Mrs. ALFRED HUNT.

The Leaden Casket. | Self-Condemned.

That Other Person.

By C. J. CUTCLIFFE HYNE.

Honour of Thieves.

A Drawn Game.

By R. ASHE KING.

-ILe Wearing of the Grecn.
By EDMOND LEPELLETIER.

Madame Sana-Gène.

Rhoda Roberts. BY HARRY LINDSAY。

By E. LYNN LINTON.

Patrlcia Kemball.

Under which Lord?

'My Love l'

Ione.

Paston Carew.

Sowing the Wind.

Gideon Flopce

By H. W. LUCY.

The Atonement of Leam Dundas. The World Well tost. The One Too Many.

By JUSTIN McCARTHY.

A Fair Sazon.

Iinley Rochford.

Dear Lady Disdain.

Dear Lady Disdain.
Camiola.

My Enemy'a Daughter. The Comet of a Season.

By JUSTIN H. MCCARTHY.

A. London Legend.

By GEORGE MACDONALD.

Heather and Snow. | Phantastes.

By L. T. MEADE.

A Soldier of Fortune. I In an Iron Grip.

By BERTRAM MITFORD.

The Gan-kunuer. The King's Assegai.

The Luck of Gerard Renshaw Fanning's Ridgeley.

By J. E. MUDDOCK.

MaId Marlan and Robin Hood.

Baslle the Jester.

By D. CHRISTIE MURRAY.

A Life's Atonement. | First Person Singnlar.

Joseph's Coat.

Coals of Firs.

Old Blazer's Hero.

Val Strange. I Hearts.

A Model Father.

or the Sea. In Direst Peril.

By MURRAY and HERMAN.

\begin{tabular}{l|l} 
The Bishop's' Bible. & Paul Jones's Alias.
\end{tabular} One Traveller Returns.

- Bail Up 1

By HUME NISBET.

Saint Ann's. By W. E. NORRIS.

A Weird Girt.

$$
\text { By G. OHNET. }
$$

Held in Bondage.
Sy OUIDA. Littie Woodea

Strathmore.

Chandos.

Under Two Flags.

Idalia.

Cecil Castlemaine's

Gage.

Tricotrin.

Puck.

Folle Farine.

A Dog of Flanders.

Pascarel.

signa.

Princess Napraxine.

Ariadne.

In a Winter City.

Friendship.

Moths.

Knffino.

Pipistrello.

A Village Commnne.

Blmbi.

Wanda.

Frescoes. 1 Othmar.

In Maremma.

syrlin. I Guilderoy.

Santa Barbara.

Two Offenders.

Gentle and Simple.

By JAMES PAYN.

Lost SIr Massingberd. High Spirits.

Less Black than We're Under Une Roof

Painted.

A Confidential Agent.

A Grape from a Thorn.

In Peril and Privation.

The Mystery of Mir-

By Proxy. [bridge.

The Canon's Ward.

Walter's Word.
Glow-worm Yales.

The Talk of the Town.

Holiday Tasks.

For Cash Only.

The Burnt Militon.

The Word and the Will

Sunny storles.

A Trying Patient. 
The Piccadilly (3/6) Novels-continued. By Mrs. CAMPBELL PRAED.

Outlaw and Lawmaker. I Chriatina Chard. By E. C. PRICE. Valentina.
The Forelgners.

\section{BY RICHARD PRYCE.}

Mira Maxwell's Affeetions.

BY CHARLES READE.

It to Never Too Lato to Singleheart andDouble. Mend.

The Donble Marrlage.

Love Me Ilttie, Love Me Lons.

The Cloister and the Hearth.

The Course of True Love.

The Autoblography of

Put Tourself in His Place.

A Terrible Temptation.

The Jilt.

By Mrs. J. H. RIDDELL. Weird Stories. By AMELIR RIVES.

Barbara Dering.

By F. W. ROBINSON.

The Hands of Justice.

BY DORA RUSSELL.

A Country Sweetheart. IThe Drift of Fato.

By W. CLARK RUSSELL.

Ocean Tragedy. Is Ie the Man ?

My Shipmate Lonise. The Good Ship 'Mo-

Alone on Wide Wide Ses hock.

The Phantom Death. The Convict Ship.

BY JOHN SAUNDERS.

Guy Waterman.

Bound to the Wheel. The Lion in the Path.

By KATHARINE SAUNDERS.

Margaret and Elizabeth Heart Salvago.

Gldeon's Roek.

The High Mills. Sebastian.

By ADELINE SERGEANT.

Dr. Endicott'e Experiment.
BY HAWLEY SMART.

Without Love or Iicence.

BY T. W. SPEIGHT.

$\Delta$ Secret of the Sea. IThe Groy Monk. BY ALAN ST. AUBYN.

A Fellow of Trinity. In Face of the World. The Junior Dean. Orchard Damerel

Master of St. Benedict's. The Tremlett Diamonds.

To his Own Master.

By R. A. STERNDALE.

The Afghan Knife.

By BERTHA THOMAS.

Proud Malsie. I The Violin.Player.

BY ANTHONY TROLLOPE.

The Way we Live Now. I Scarborongli'a Family.

Fran Frohmann. | The Land-Leaguers.

BY FRANCES E. TROLLOPE.

Like ships upon the Anno Furness.

Sea.

Mabel'a Progress.

By IVAN TURGENIEFF, \&c.

Stories from Foreign Novelists.

BY MARK TWAIN.

The American Claimant. I Pudd'nhead Wilson.

The£1,000,000Bank-note. Tom \$awyer, Detectivo. Tom Sawyer Abroad.

By C. C. FRASER-TYTLER. Mistreas Judith.

By SARAH TYTLER.
Lady Bell.
Buried Dlamonds.

Buried Diamonde, ALEN UPWARD.

The Queen against Owen.

The Prince of Balkistan.

By E. A. VIZETELLY.

The Scorpion: A Romance of Spain. By J. S. WINTER.

A Soldier's Children.

BY MARGARET IVYNMAN.

My Flirtations.

The Downiall.

The Dream.

By E. ZOLA.

Dr. Paseal
Money. I Lourdes.
The Fat and the Thin. Rome.

CHEAP EDITIONS OF POPULAR NOVELS.

Post 8vo, illustrated boards, 25, each.

BY ARTEMUS WARD.

Artemus Ward Complete.

The Fellah.

BY EDMOND ABOUT.

By HAMILTON AÏDÉ.

Carr of Carrlyon. | Confldences.

By MARY ALBERT.

Brooke Finchley'B Daughter.

By Mrs. ALEXANDER.

Maid, wife or Widow 7 | Valerle's Fate.

By GRANT ALLEN.

Philistia.

Btrange Storles.

Babylon

The Great Tabeo.

For Maimie's Sake.

In all Shacles.

The Beckoning Hand.

The Devil's Die.

The Tents of Shom.

Dumaresq's Daugh ter

Dnchess of Powysland.

Blood Royal.

Ivan Greet's Master. piece.

The Scall ywar.

This Mortal Coil.

BY E. LESTER ARNOLD.

Phra the Phoniclan.

By Rev. S. BARING=GOULD. Red spider.

I $\Sigma \nabla 0$.
BY FRANK BARRETT.

Fettered for Iifo.

Little Lady Iinton.

Between Iffe \& Death.

The Sln of Olga Zasaou.

lich.

Folly Morrison.

Lleut. Barnabs.

Honest Davie.

A Prodigal's Progress.

Found Gullty.

A Recolling Vengeance.

For Love and Honour.

John Ford; and His

Helpmate.

\section{BY SHELSLEY BEAUCHAMP.} Grantley Grange.

By Sir W. BESANT and J. RICE. Ready-Money Mrortiboy $\mid$ By Celia's Arbour. My Little Girl

With Harp and Crown.

This Son of Vulean.

The Golden Butterfy. Chaplain of the Fieet.

The Seamy side.

The Case of Mr. Lueraft.

In Trafalear's Bay.

The Monks of Thelema. The Ten Years' Tenant

By Sir WALTER BESANT.

All Sorts and Condi- For Faith and Freedom. tions of Men.

The Captains' Room.

All in a Garden Fair.

Dorothy Forster.

Unele Jack.

The World Went Very

Well Then.

Children of Gibeon.

Horr Pauluz.
To Call Her Mine.

The Bell of St. Paul's.

The Holy Rose.

Armorel of Lyonesse.

S. Katherine's by Tower.

Verbena Camellia ste.

phanotis.

The Ivory Gate.

Tlie Erebel Queen. 
Two-ShILLING Novels-continued. BY AMBROSE BIERCE.

In:the Midat of Iife.

By FREDERICK BOYLE.

Camp Notes. Chronicles of No-man's

Bavage Life. Land.

BY BRET HARTE.

Caltfornlan Stories.

Gabriel Conroy.

The Iuck of Roaring

Camp.

An Helress of Red Dog.

Flip. i Maraja.

A Phyllis of the Slerras.

A Waif of the Plalns.

A Ward of the Golden

Uncle Sam at Home.

By ROBERT BUCHANAN.

Shadow of the Sword. | The Martyrdom of Ma-

A Child of Nature.

God and the Man.

Love IIe for Ever.

Foxplove Manor. deline.

Annan Water.

The New Abelard. Matt.

The Master of the Mine. The Heir of Linne. BY HALL CAINE.

The Shadow of a Crime. The Deemster.
A Son of Hagar.

By Commander CAMERON.

The Cruise of the 'Black Prince.'

By MrS. LOVE'T'T CAMERON.

Decelvers Ever. I Jullet's Guardian.

BY HAYDEN CARRUTH.

The Adventures of Jones.

BY AUSTIN CLARE.

For tho Love of a Lass.

By Mrs. ARCHER CLIVE.

Paul Ferroll.

Why Paul Ferroll Killed his Wife.

By MACLAREN COBBAN.

The Cure of Sorls. I The Red Sultar.

By C. ALLSTON COLLINS.

The Bar Sinister.

By MORT. \& FRANCES COLLINS.

Sweet Anne Page. I Sweet and Twenty.

Transmigration. The Village Comedy.

From Midnight to Mid. You Play me False.

night.

Blacksmith and Scholar

A Fight with Fortune. Frances.

By WILKIE COLLINS.

Armadale.

I My Miscellanies.

After Dark.

The Woman in White.

No Name.

Antonina.

Basil.

Hide and seek.

The Dead Secret.

Qneen of Hearts.

Miss or Mrs. ?

The New Magdalen.

The Frozen Doep.

The Law and the Lady.

The Two Destinles.

The Haunted Hotel.

A Rogue's Life.

The Moonstone.

Man and Wife.

Poor Mise Finch.

The Fallen Ieaves.

Jezebel's Daughter.

The Black Robe.

t Heart and Sclence.

- I Say No !

The Evil Genins.

Little Novels.

Legacy of Cain.

Blind Love.

By M. J. COLQUHOUN.

Every Inch a Soldier.

By DUTTON COOK.

Leo.

| Panl Foster's Danghter.

By c. EGBERT CRADDOCK.

The Prophet of the Great Smoky Mountains. BY MAT'T CRIM.

The Adventures of a Fair Rebel.

By B. M. CROKER.

Pretty Miss Neville.

Dlana Barrington.

"To Lot."

By

A Bird of Passage.

Proper Pride.

A Family Likeness.

Hearts of Gold.

y. CYPLES.

By ALPHONSE DAUDET.

The Evangelist; or, Port Salvation.

BY ERASMUS DAWSON.

The Fountain of Youth.
By JAMES DE MILLE.

A Castle in Spain.

By J. LEITH DERWENT.

Our Lady of Tears. | Clrce's Lovers.

BY CHARLES DICKENS.

Sketches by Boz. | Nicholas Nicklehy.

Oliver Twiat.

By DICK DONOVAN.

The Man-Hunter.

rracked and Taken.

Caught at Last 1

Wanted!

Who Polsoned Hetty

Duncan ?

Man from Manchester.

A Detective's Triamphs

From Information Recelved.

Tracked to Doom.

Link by Link

Suspicion Arouaed.

Dark Deeds.

In the oaw.

By Mrs. ANNIE EDWARDES.

A Point of Honour. | Archie Iovell.

By $M$. BETHAM=EDWARDS.

Felicta. I Kitty.

Roxy.

By EDWARD EGGLESTON.

By G. MANVILLE FENN.

The New Mistress. I WItness to the Deed

BY PERCY FITZGERALD.

Bella Donna.

Never Forgotten.

Polly.

Fatal Zero

Second Mrs. Tillotson.

Seventy - five Brooke Street.

Strange Secret.

BY ALBANY DE FONBLANQUE. Fllthy Lucre.

Olympla. By R. B. FRANCILLON.

One by One.

A Real Queen.

Queen Cophetna.

King or Knave?

Romances of the Law.

Ropes of Sand.

A Dog and his shadow.

By HAROLD FREDERIC.

Seth's Brother's Wife. | The Lawton Girl.

Prefaced by Sir BARTLE FRERE.

Pandurang Hari.

One of Two.

By HAIN FRISWELL.

BY EDWARD GARRETT

The Cape1 Girls.

By GILBERT GAUL.

A Strange Manuscript.

By CHARLES GIBBON.

Robin Gray.

Fancy Free.

For Lack of Gold.

What will the Worid

say?

In Love and War.

For the King.

In Pastnres Green.

Queen of the Meadow.

A Heart's Problem.

The Dead Heart.

In Honour Bound.

Flower of the Forest.

The Braes of Yarrow.

The Golden Shaft.

of High Degree.

By Mead and Stream.

Loving a Dream.

A Hard Knot.

Heart's Delight.

Blood-Money.

BY WILLIAM GILBERT.

Dr. Anstin's Guests. | The Wtzard of the James Duke.

By ERNEST GLANVILLE.

The Lost Helress.

A Pair Colonist.

BY HENRY GREVILLE.

A Noble Woman. I Nikanor.

BY CECIL GRIFFITH.

Corinthia Marazion.

By SYDNEY GRUNDY.

The Days of his Vanjty.

BY JOHN HABBERTON.

Brueton's Bayou. i Country Luck. By ANDREW HALLIDAY.

Every-day Papers.

By Lady DUFFUS HARDY.

Paul Wynter's sacrifico. 
Two-Shilling Novels-continued. BY THOMAS HARDY.

Onder the Greenwood Tree.

BY J. BERWICK HARWOOD. The Tenth Earl.

Garth.

BY JULIAN HAWTHORNE.

Eilice Quentin.

Fortune's Fool.

Miss Cadogna.

Sebastian stromo.

Dust.

Ivan de Blron.

By Sir ARTHUR HELPS.

BY HENRY HERMAN.

A Leading Lady.

$$
\text { By HEADON HILL. }
$$

Zambra the Detective.

Beatrix Randolph.
Love-or a Name.
David Poindexter's Dis-
appearance.
The Spectre of the Camera.

$$
\text { By JOHN HILL. }
$$

Treanon Felony.

By MrS. CASHEL HOEY.

The Lover's Creed.

BY MrS. GEORGE HOOPER.

The House of Raby.

By TIGHE HOPKINS.

Twizt Love and Duty.

By Mrs. HUNGERFORD.

A Maiden all Foriorn. A Mental struggle.

In Durance Vile.

Marvel.

Lady Verner's Flight.

By Mrs. ALFRED HUNT.

Thornicroft's Model. | Seli.Condemned.

That Other Person. The Leaden Casket.

Fated to be Free.

By JEAN INGELOW.

By WM. JAMESON.

uy Dead selr.

BY HARRIETT JAY.

The Dark Colleen. Q Queen of Connaught.

BY MARK KERSHAW.

Colonial Facts and Fictions.

By R. ASHE KING.

A Drawn Game. Aassion's Slave.

'The Wearing of the Bell Barry.

The Lindsays.

By JOHN LEYS.

BY E. LYNN LINTON.

Patricia Kembali.

The World Well Lost.

Under which Lord ?

Paston Carew.

'My Love 1"

Ione.

The Atonement of Leam

Dundas.

With a silken Thread.

The Rebel of the Familly.

Sowing the wind.

GIdeon Fleyce.

BY HENRY W. LUCY.

By JUSTIN McCARTHY.

Dear Irdy Disdain.

Waterdale Neighbonrs. Donna Quixote.

My Enemy's Daughter. Maid of Athens.

A Fair Saxon.

Linley Rochford.

Miss Misanthropo. The Comet of a Season. The Dictator. Red Dlamonds. By HUGH MACCOLL.

Mr. Stranger' sealed Packet. Quaker Cousins.

BY AGNES MACDONELL.

BY KATHARINE S. MACQUOID. The Evil Eye. | Lost Rose.

By W. H. MALLOCK.

A Romance of the Nine. I Tho New Repusllo. teenth Century.
BY FLORENCE MARRYAT.

Open i Sesame ! |A Harvest of Wiid Oats. Fighting the Air.

Written in Fire.

BY J. MASTERMAN.

Half-a-dozen Danghters.

BY BRANDER MATTHEWS.

A secret of the Sea.

BY LEONARD MERRICK.

The Man who was Good.

By JEAN MIDDLEMASS.

Touch and Go. / Mr. Dorlllion.

By Mrs. MOLESWORTH.

Hathercourt Rectory.

By J. E. MUDDOCK.

Stories Weird and Won-| From the Bosom of the

The Dead Man's Secret.

By D. CHRIS TIE MURRAY.

A Trodel Father.

Joseph's Coat.

Coals of Fire.

Val Strange.

Old Blazer's Hero.

Hearts.

The Way of the World

Cynic Fortune.

By MURRAY and HERMAN.

One Traveller Returns. | The Bighops' Bible.

Paul Jones's Alia..

BY HENRY MURRAY.

A Game of Bluff. By HUME NISBET.

'Ball Up|" | Dr.Bernard St.Vincent. By ALICE O'HAN LON.

The Unforeseen. | Chance? or Fate? By GEORGES OHNET.

\begin{tabular}{l|l} 
Dr. Rameau. & A Weird Gift. \\
A Last Love.
\end{tabular}

By Mrs. OLIPHANT. \begin{tabular}{l|l} 
Whiteladies. & Tho Greateat Helress In \\
The Primrose Path. & Eogiand.
\end{tabular}

By Mrs. ROBERT O'REILLY.

Phwbe's Fortunes.

Held in Bondage.

Strathmore.

Chandos.

Idalia.

Under Two Flagn.

Tricotrin.

Puck.

Folle Farine.

A Dog of Flandere.

Pascarel.

Signa.

Princess Napraxine.

In a Winter City.

Ariadne,

Frlendship.

Pipistrello.

A Village Communo.

Wanda.

othmar.

Frescoes.

In Maremms.

Guilderoy.

Rufino.

Syrlin.

Santa Barbara.

Ouida's Wisdom, Wit,

BY MARGARET AGNES PAUL.

Gentle and Simple.

Lady Lovelace.

By c. L. PIRKIS.

By EDGAR A. POE.

The Mystery of Marie Roget.

By Mrs. CAMPBELL PRAED.

The Romance of a Station.

The Soul of Countess Adrian.

Outlaw and Lawmaker.

\begin{tabular}{l|l} 
Valentlua. & Mrs. La \\
The Foreigners. & Gerald.
\end{tabular}

By E. C. PRICE.

By RICHARD PRYCE.

Migs Maxwell's Afectlons. 
Two-ShILling Novels-continued. BY JAMES PAYN.

Bentínck'a Tutor. Murphy's Master. A Connty Family.

At Her Mercy.

Cecil's Tryst.

The Clyfiards of Cly fro.

The Foster Brothers.

Found Dead

The Best of Husbands.

Walter's Word.

Halves.

Fallen Fortunes.

Aumorous Stories.

$£ 200$ Reward.

A Marine Resldence.

Mirk Abbey.

By Proxy.

Under One Roos.

High Spirits.

Carlyon's Year.

From Exile.

For Cash Only.

Kit.

The Canon's Ward.

The Talk of the Town. Holiday Tasks. A Perfect Treasure. Vhat He Cost Her. $A$ Confidential Agent. Glow-worm Tales. The Burnt Million. Sunny Stories.

Loat Sir Massingberd. A Woman's Vergeance. The Family Scapegrace. Gwendoline's Harvest. Ilke Father, Iike Son. Married Beneath Him. Not Wooed, but Won. Less Black than Wo're Painted.

Some Private Views.

A Grape from a Thorn.

The Mystery of Mirbridge.

The Word and the Wul. A Prince of the 3lood. A Trying Patl
S READE.

It is Never Too Late to A TerribleTemptation. Mend.

Christle Johnstone.

The Double Marriage.

Put Yoursalf in His Place

Love Me Iittle, Love Me Long.

The Cloister and the Hearth.

The Course of True Love.

The Jilt.

The Antoblography of a Thief.

Weird Storles.

Fairy Water.

Her Mother' Darling.

The Prince of Wales's Garden Party. Idle Tales.

Barbara Dering. Foul Play.

The W andering Heir.

Hard Cash.

Singleheart and Double. Iace.

Good storlea of Men and other Animals.

Peg Woffington.

Griffith Gaunt.

A Perilous Secret.

A Simpleton.

Readiana.

A Woman-Eater.

RIDDRLI

The Unirhabited Fouse. The Mystery in Raluce. Gardens.

The Nun's Curso.

By F. W. ROBINSON.

Women are Strange. I The Hands of Justice. By JAMES RUNCIMAN.

Stippers and Shellback.

Grace Baimaign's Sweetheart.

Schools and Scholars.

By W. CLARK RUSSELL.

Round the Galley Fire. The Romance of Jenny on the Fo'k'sle Hiead.

In the Middle Watch.

A Voyage to the Capo.

A Book for the Ham. mock.

The Mystery of the

Ocean Btar.

By GEORGE AUGUSTUS SALA. Gaslight and Daylight.

BY JOHN SAUNDERS.

Guy Waterman. Harlowe.

An Ocean Tragedy.

My Shipmato Loulse.

Alone on a Wide Wide Sea.

1'lue Two Dreamer:

BY KATHARINE SAUNDERS.

Joan Merryweather.

The High Mills.

Heart Balvage.

Sebastian.

Margaret and Ellza.

By GEORGE R. SIMS.

T.ogues and Vagabonds. Tirkletop a Crime.

The Ring $0^{\prime}$ Bells.

Mary Jane's Memoirs.

Mary Jane Married.

Tales of To day. Zeph.

My Two WIres.

Memotrs of a Landlady. scenes from the show.

Dramas of Iife. Ten Commandments. By ARTHUR SKETCHLEY.
BY HAWLEY SMART.

Without Love or Iicence.

By T. W. SPEIGHT.

The Mysteries of Heron, Back to Life.

Dyke.

The Golden Iroop.

Hood winked.

By Devious Ways.

BY ALAN ST. AUBYN.

A Fellow of Trinity. | Master of st. Benedict's

The Junior Dean. To His Own Master.

By R. A. STERNDALE.

The Afghan Knife.

By R. LOUIŚ STEVENSON.

New Arablan Nights. I Prince Otto.

By BERTHA THOMAS.

Cressida.

Proud Malsie. The Vioun-Player.

BY WALTER THORNBURY.

Tales for the Marines. 1 Old Stories Retold.

By T. ADOLPHUS TROLLOPE. Dlamond Cut Diamond.

By F. ELEANOR TROLLOPE.

Ilike Ships upon the Anne Furness. Soa.

Mabel's Progress.

BY ANTHONY TROLLOPE.

Frau Frobmann.

Marion Fay.

Kept In the Dark.

John Caldigate.

The Way We Iive Now.

The Land-Leaguers.

By J. T. TROWBRIDGE.

Farnell's Folly.

By IVAN TURGENIEFF, \&c。

Storie 6 from Forolgn Novelists.

By MARK TWAIN.

A Pleasure Trip on the Life on the Misslsalppl. Continent.

The Gilded Age.

Huckleberry Finn.

MarkTwaln' Skotcheg.

Tom Sawyer.

A Tramp Abroad

Stolen White Elephant.

The Prince and the Pauper.

A Yankee at the Court of King Artbur.

The $\$ 1,000,000$ Bank. Note.

By c. c. FRASER-TYTLER.

Mllotress Judith.

BY SARAH TYTLER.

The Bride' 3 Pass.

Kuried Diamonds.

St. Mungo's City.

Lady Bell.

Noblesse Oblige.

Disappeared.

BY ALLEN UPWARD.

The Queen agrinst Owen.

The Huguenot Famlly. The Biackhall Ghorts. What sheCameThrough Beauty and the Beast. Citoyerne Jaquelino.

\section{By AARON WATSON and LILLIAS WASSERMANN.}

The Marquis of Carabos.

Truat-Money.

By WILLIAM WESTALL.

By Mrs. F. H. WILliamison.

A Child widow.

BY J. S. WINTER.

Cavalry Life. 1 Regimental Legonda

By H. F. WOOD.

The Prssenger from Scotland Yard.

Tho Englishman of the Rue Cafn.

Sabira.

By Lady WOOD.

BY CELIA PARKER WOOLLEY.

Rachel Armstrong ; or, Love and Theology. BY EDMUND YATES.

The Forlorn Hope.

Land st Last.

A Match in the Dark. 



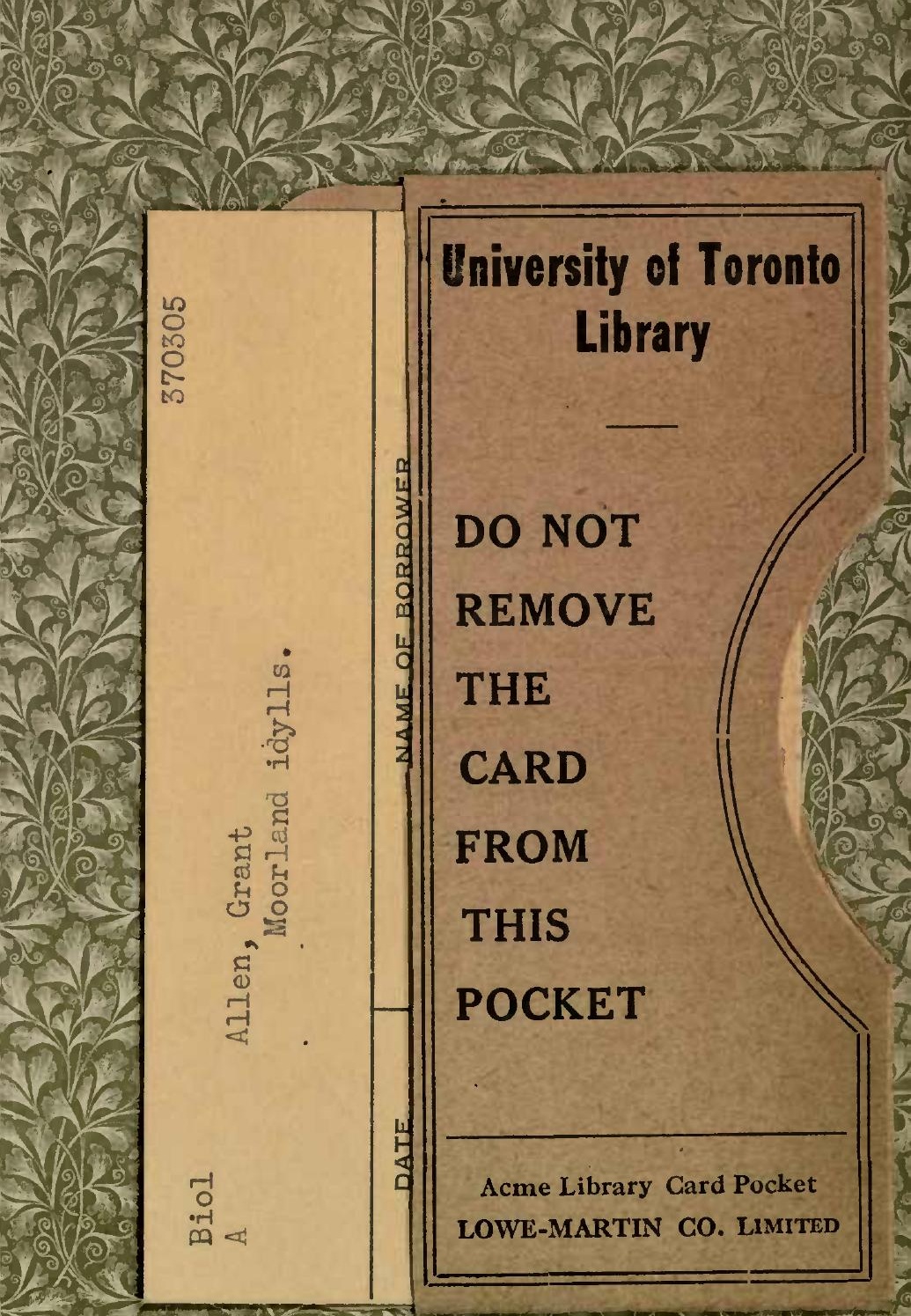


